FHWA/IN/JTRP-2010/14

Final Report

INDIANA PAVEMENT PRESERVATION PROGRAM

Ghim Ping (Raymond) Ong

Tommy Nantung

Kumares C. Sinha

January 2010 


\section{TECHNICAL SUMMARY}

Technology Transfer and Project Implementation Information

\section{INDIANA PAVEMENT PRESERVATION PROGRAM}

\section{Introduction}

State highway agencies are facing immense pressure to maintain roads at acceptable levels amidst the challenging financial and economic situations. In recent years, pavement preservation has been sought as a potential alternative for managing the pavement assets, believing that it could provide a cost-effective solution in maintaining infrastructural conditions and meeting user expectations.

While the concept of pavement preservation is has been established at the project level, there is still a significant gap in implementing elements of pavement preservation at the network level, especially within the pavement management system. Recognizing the need to integrate both project and network level pavement preservation into a coherent pavement management structure, this research study attempts to develop a framework for pavement preservation implementation within the state of Indiana. Several elements related to integrating pavement preservation in a pavement management framework are studied: (i) determining triggers for pavement preservation treatments for use in a PMS, (ii) developing performance models for preservation treatments, (iii) developing a remaining service life approach for strategy comparison at the project level, and (iv) developing a pavement preservation framework that integrates the districts and the central office of a state highway agency. These elements when properly resolved can allow a truly comprehensive pavement management system with consideration to preservation concepts within the Indiana Department of Transportation.

\section{Findings}

The first part of the report explores the development of thresholds that allow the "triggering" of preservation and rehabilitation treatments within a pavement management system. Two different procedures to develop intervention levels for pavement preservation treatments are studied. The first procedure involves using historical decisions made by an agency to determine treatment intervention levels, while the second procedure seeks expert opinions to develop relevant treatment decision matrices. Based on the findings presented in the report, distress-based decision matrices are found to be more desirable, primarily because it can be easily adopted for new and innovative pavement materials and preservation treatments.

The second part of the report develop pavement performance models (both long term pavement performance and short term performance jumps) for various asphalt and PCC preservation treatments. Costs for preservation treatments are also identified. These models can be used in a pavement management system to allow network level planning and programming of pavement activities.

A remaining service life approach for pavement preservation strategy selection is developed to evaluate competing pavement strategies at the project level. An illustration is presented in report to demonstrate the application of remaining service life in project level pavement management. It is found in the report that pavement preservation can be a costeffective solution to preserve our pavement assets on a project level.

The last part of the report presented a pavement preservation framework that integrates project level evaluation at the districts and 
network level evaluation at the central office. The remaining service life approach is adopted in the selection of pavement preservation projects. Using a sample highway network from the state of Indiana, it is found that the proposed framework is capable of improving the remaining service life of the pavement network as compared to the traditional "worse pavement first" concept. This demonstrates the effectiveness of the pavement preservation concept where agencies can look forward to enjoy a much better remaining service life extension to highway pavement assets when compared to the traditional "worst pavement first" approach.

\section{Implementation}

The findings made in this report can be implemented by INDOT in the following areas: (i) use of pavement preservation treatment triggers at both network and project levels; (ii) adopt the developed pavement preservation treatment performance models in the pavement management system; (iii) use of remaining service life concept in strategy evaluation and project selection; (iv) integration of pavement preservation framework in the network-level pavement management system. This allows INDOT to better manage their highways to bring the most benefits with a minimum cost.

\section{Contacts}

For more information:

Prof. Kumares C. Sinha

Principal Investigator

School of Civil Engineering

Purdue University

West Lafayette IN 47907

Phone: (765) 494-2211

Fax: (765) 496-7996
Indiana Department of Transportation

Office of Research, 1205 Montgomery Street, P.O.

Box 2279, West Lafayette, IN 47906

Phone: (765) 463-1521

Fax: (765) 497-1665

Purdue University

Joint Transportation Research Program

School of Civil Engineering

West Lafayette, IN 47907-1284

Phone: (765) 494-9310

Fax: (765) 496-1105 


\section{INDOT Research Project Implementation Plan}

Date: 01-21-2010

Research Project Number: SPR-3092

Project Title: Indiana Pavement Preservation Program

Principal Investigator (PI): G.P. Ong, T.E. Nantung and K.C. Sinha

Project Advisor (PA): T. E. Nantung Signature:

Principal Implementor (PIM):

Signature:

INDOT Strategic Goal Impact Areas (select all that the implementation of this project will impact):

$\square$ Mobility $\square$ Safety $\square$ Economic Development $\square$ Customer Service

$\bigotimes$ Resource Management $\square$ Training

Summary of Implementation Plan:

Item \#1: Use of Pavement Triggers in Network Level and Project Level Pavement Management

Action: Implement the pavement management triggers in the pavement management system.

- Table 4.6 (page 39) of report for asphalt pavement preservation treatments

- Table 4.7 (page 40) of report for PCC pavement preservation treatments

Action: Provide the following table (could be made into a small pocket-sized card) to district engineers for easy pavement treatment selection in the field:

- Table 4.9 (page 41) of report for quick field guide of pavement preservation treatments

Item \#2: Use of Performance Models in Pavement Management Systems

Action: Implement the long term pavement performance and short term effectiveness models shown in Chapter 5 of the report in the INDOT pavement management system.

Item \#3: Use of Remaining Service Life in Pavement Preservation Treatment Selection Action: Implement the remaining service life approach in evaluating future pavement preservation projects.

Item \#4: Use of Remaining Service Life Approach in Pavement Preservation Project Selection at the District

Action: Send the spreadsheet and Appendix III to districts as an exercise to understand pavement preservation project selection at the district level. 
Item \#5: Integrating Pavement Preservation Concept in Pavement Management

Action: Adopt the pavement preservation framework shown in Figure 6.1 (page 56) of the report.

There needs to be close interaction and feedback between the Central Office and Districts in terms of pavement preservation integration within a pavement management system.

Note: If more than one implementor recommended, please fill in the information on each implementor's implementation items:

Name of Implementor/User: $\quad$ Signature:

Responsible for Implementing:

Help or resources needed for implementation (e.g., help from PI, funding, equipment, etc.):

Name of Implementor/User: $\quad$ Signature:

Responsible for Implementing:

Help or resources needed for implementation (e.g., help from PI, funding, equipment, etc.):

Name of Implementor/User: $\quad$ Signature:

Responsible for Implementing:

Help or resources needed for implementation (e.g., help from PI, funding, equipment, etc.):

Signatures of SAC members:

Please send a copy of this form to the INDOT Research \& Development Office and FHWA with the final report. 


\title{
DRAFT FINAL REPORT
}

FHWA/IN/JTRP-2010/14

\section{INDIANA PAVEMENT PRESERVATION PROGRAM}

\author{
By \\ Ghim Ping (Raymond) Ong \\ Visiting Assistant Professor, School of Civil Engineering \\ Tommy Nantung \\ Section Manager, Indiana Department of Transportation \\ and \\ Kumares C. Sinha \\ Olson Distinguished Professor of Civil Engineering \\ Joint Transportation Research Program \\ Project No. C-36-78P \\ File No. 03-10-15 \\ SPR-3092 \\ In Cooperation with the \\ Indiana Department of Transportation \\ and the Federal Highway Administration
}

The contents of this report reflect the views of the authors, who are responsible for the facts and the accuracy of the data presented herein. The contents do not necessarily reflect the official views or policies of the Indiana Department of Transportation or the Federal Highway Administration. This report does not constitute a standard, specification or regulation

Purdue University

West Lafayette, IN, 47907

January 2010 
TECHNICAL REPORT STANDARD TITLE PAGE

\begin{tabular}{|c|c|c|}
\hline $\begin{array}{l}\text { 1. Report No. } \\
\text { FHWA/IN/JTRP-2010/14 }\end{array}$ & 2. Government Accession No. & 3. Recipient's Catalog No. \\
\hline \multirow{2}{*}{\multicolumn{2}{|c|}{$\begin{array}{l}\text { 4. Title and Subtitle } \\
\text { Indiana Pavement Preservation Program }\end{array}$}} & $\begin{array}{l}\text { 1. Report Date } \\
\text { January } 2010\end{array}$ \\
\hline & & 6. Performing Organization Code \\
\hline \multicolumn{2}{|c|}{$\begin{array}{l}\text { 7. Author(s) } \\
\text { Ong Ghim Ping, Tommy Nantung and Kumares C. Sinha }\end{array}$} & $\begin{array}{l}\text { 8. Performing Organization Report No. } \\
\text { FHWA/IN/JTRP-2010/14 }\end{array}$ \\
\hline \multirow{2}{*}{\multicolumn{2}{|c|}{$\begin{array}{l}\text { 9. Performing Organization Name and Address } \\
\text { Joint Transportation Research Program } \\
\text { 1284 Civil Engineering Building } \\
\text { 550 Stadium Mall Drive, Purdue University } \\
\text { West Lafayette, IN 47907-1284 }\end{array}$}} & 10. Work Unit No. \\
\hline & & $\begin{array}{l}\text { 11. Contract or Grant No. } \\
\text { SPR-3092 }\end{array}$ \\
\hline \multirow{3}{*}{\multicolumn{2}{|c|}{$\begin{array}{l}\text { 12. Sponsoring Agency Name and Address } \\
\text { Indiana Department of Transportation } \\
\text { State Office Building, } 100 \text { North Senate Avenue } \\
\text { Indianapolis, IN } 46204\end{array}$}} & 13. Type of Report and Period Covered \\
\hline & & Final Report \\
\hline & & 14. Sponsoring Agency Code \\
\hline
\end{tabular}

16. Abstract

State highway agencies are facing immense pressure to maintain roads at acceptable levels amidst the challenging financial and economic situations. In recent years, pavement preservation has been sought as a potential alternative for managing the pavement assets, believing that it would provide a cost-effective solution in maintaining infrastructural conditions and meeting user expectations. This study explores the potential of pavement preservation concepts in managing the agency's pavement assets by attempting to integrate pavement preservation considerations within the network-level pavement management system. Several elements are studied in the report: (i) determining triggers for pavement preservation treatments for use in a PMS, (ii) development of performance models for preservation treatments, (iii) developing a remaining service life approach for strategy comparison at the project level, and (iv) developing a pavement preservation framework that integrates the districts and the central office of a state highway agency. It is found that distress-based decision matrices are found to be more desirable as triggers in the pavement management system, primarily because it can be easily adopted for new and innovative pavement preservation materials and treatments. Pavement performance models (both long term pavement performance and short term performance jumps) are developed and incorporated within a pavement management systems used by highway agencies. By adopting a remaining service life approach to evaluate competing pavement strategies at the project level, it is found that pavement preservation can be a cost-effective solution to preserve our pavement assets on a project level. A pavement preservation framework to integrate project and network level evaluations at the districts and network level evaluation at the central office is developed using the remaining service life concept. Using a sample highway network from the state of Indiana, it is found that the proposed framework is capable of improving the remaining service life of the pavement network as compared to the traditional "worse pavement first" concept. This demonstrates the effectiveness of the pavement preservation concept where agencies can look forward to enjoy a much better remaining service life extension to highway pavement assets when compared to the traditional "worst pavement first" approach.

\section{Key Words}

Pavement Preservation, Pavement Management, Performance Models, Optimization.
18. Distribution Statement

No restrictions. This document is available to the public through the National Technical Information Service, Springfield, VA 22161
19. Security Classif. (of this report)

Unclassified
20. Security Classif. (of this page)

Unclassified
21. No. of Pages 


\section{ACKNOWLEDGMENTS}

The authors hereby acknowledge the constant support provided by the members of the Study Advisory

Committee: Samy Noureldin and Ju-Sang Lee of INDOT Research Division; Shakeel Baig, Andrew Carter, Krystal Cornett, Dave Dallas, Kumar Dave, Khalil Dughaish, Dwayne Myers, Jewell Stone, Todd Shields and Bill Tompkins of INDOT; Thomas Duncan of FHWA; and Mike Byers from the industry. 


\section{TABLE OF CONTENTS}

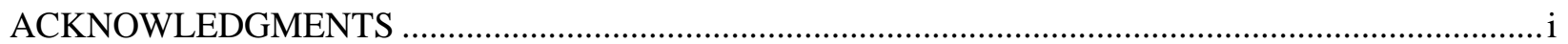

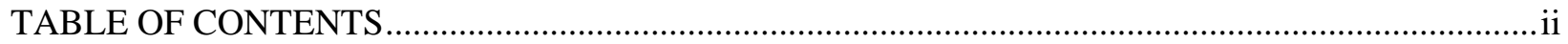

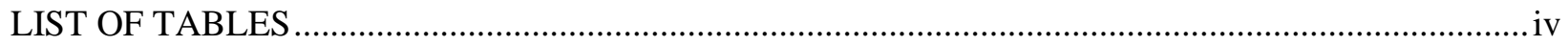

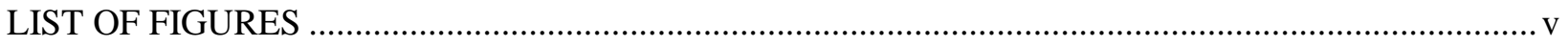

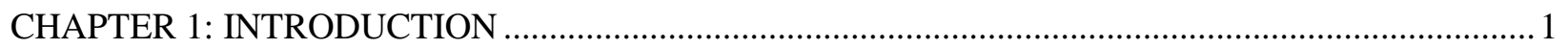

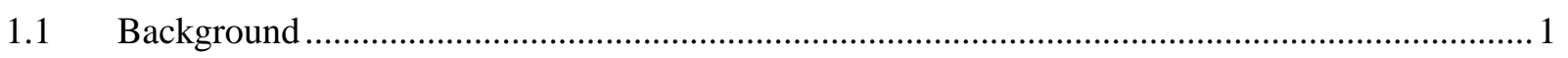

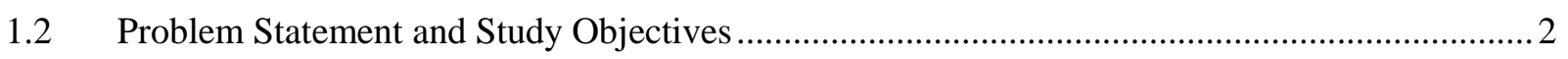

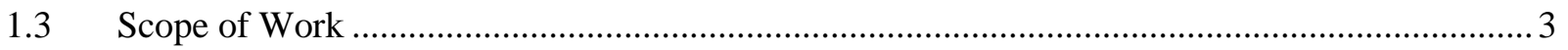

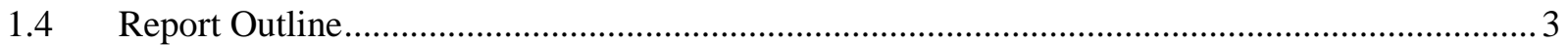

CHAPTER 2: EXISTING STATE OF PRACTICE IN PAVEMENT PRESERVATION ........................ 4

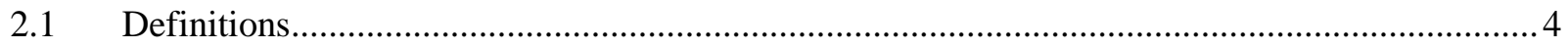

2.2 A Generic Framework for Pavement Preservation ..............................................................5

2. 3 Pavement Preservation Treatments Selection Guidelines ........................................................ 8

$2.4 \quad$ Evaluating Pavement Preservation Treatment Effectiveness .................................................. 12

2.4.1 Short Term Pavement Treatment Effectiveness.............................................................. 13

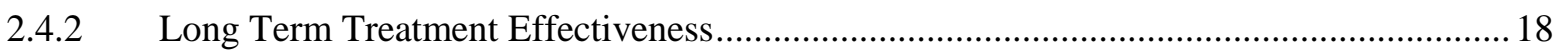

2.5 Programming of Pavement Preservation and Rehabilitation Treatments ................................ 21

2.6 Need for Pavement Preservation Framework in Indiana ........................................................22

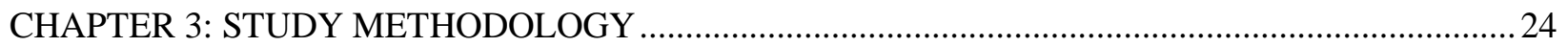

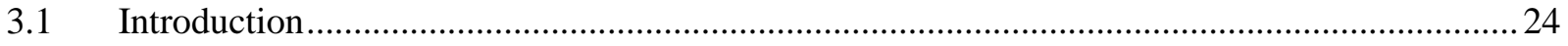

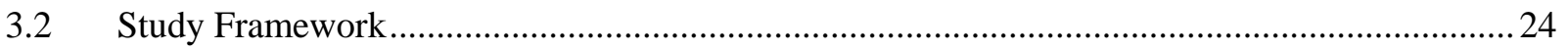

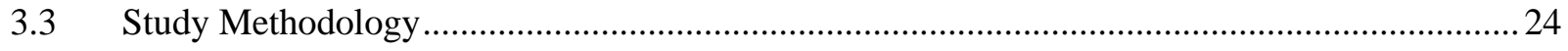

3.3.1 Integrating Pavement Preservation Concepts within a Pavement Management System .... 24

3.3.2 Pavement Preservation at the District Level ............................................................... 26

CHAPTER 4: DEVELOPMENT OF THRESHOLD LEVELS FOR PAVEMENT PRESERVATION

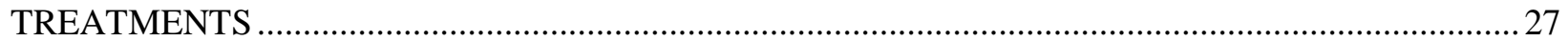

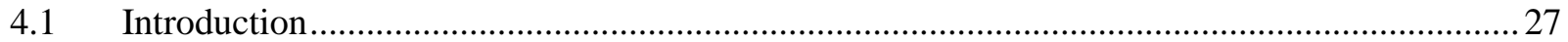

4.2 Determining Pavement Threshold Levels using Historical Data ...........................................28 


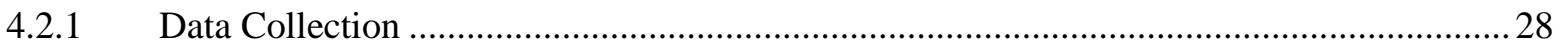

4.2.2 Approach to Determine Intervention Levels from Historical Decisions............................ 31

4.2.3 Pavement Thresholds from Historical Data ................................................................... 31

4.3 Determining Pavement Thresholds using Expert Opinions ..................................................... 34

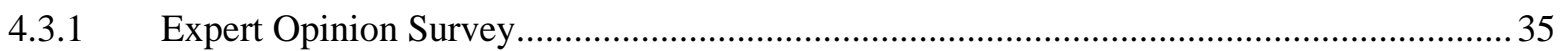

4.3.2 Procedure to Determine Decision Matrix for Pavement Treatment Selection .................... 35

4.3.3 Decision Matrices for Preservation Treatments ............................................................... 36

4.4 Applicability of Procedures to Incorporate Pavement Preservation Considerations in PMS ..... 41

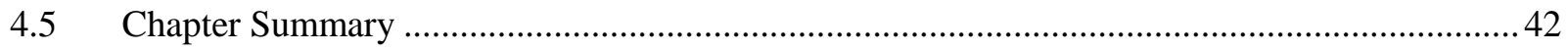

CHAPTER 5: SHORT AND LONG TERM EFFECTIVENESS OF PAVEMENT PRESERVATION

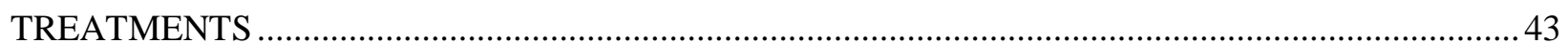

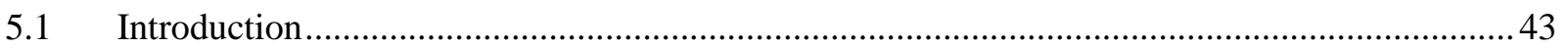

5.2 Long Term Pavement Performance for Existing Pavements ................................................. 43

5.3 Performance Models for Pavement Preservation Treatments ................................................. 45

5.3.1 Short Term Effectiveness of Pavement Preservation Treatments ..................................... 45

5.3.2 Long Term Effectiveness of Pavement Preservation Treatments ...................................... 48

5.4 Remaining Service Life Approach for Pavement Preservation ............................................... 49

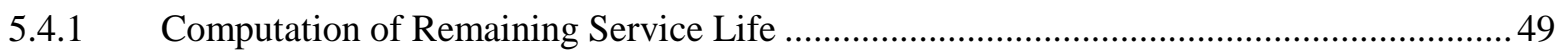

5.4.2 Use of Remaining Service Life in Pavement Strategy Comparison ..................................50

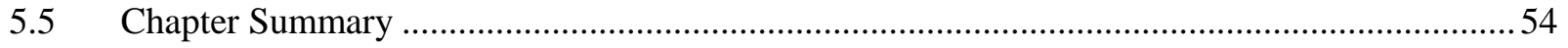

CHAPTER 6: PAVEMENT PRESERVATION FRAMEWORK FOR A STATE HIGHWAY AGENCY

(n)

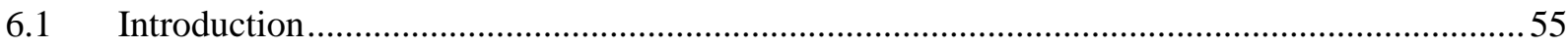

6.2 A Framework for Pavement Preservation Implementation ......................................................55

6.4 Preservation Project Selection at the District Level..............................................................58

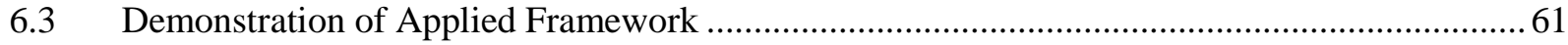

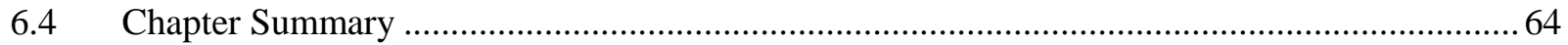

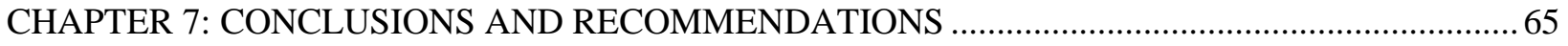

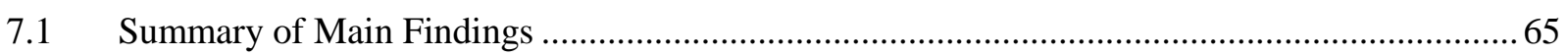

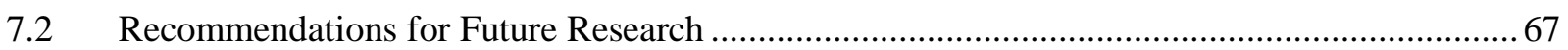

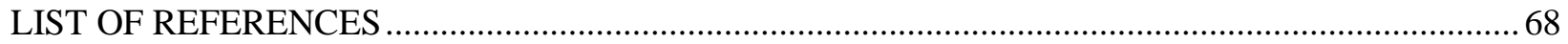

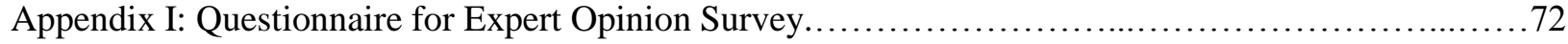

Appendix II: Evaluating Average Annual Freezing Index ..................................... 85

Appendix III: Using Excel to Perform Preservation Project Selection at the District Level ..............89 


\section{LIST OF TABLES}

Table

Page

Table 2.1: Pavement preservation guidelines

Table 2.2: Types of pavement preservation techniques

Table 2.3: Caltrans asphalt pavement preservation treatment selection guidelines 10

Table 2.4: Caltrans PCC pavement preservation treatment selection guidelines 11

Table 2.5: ACPA jointed PCC pavement preservation treatment selection guidelines 11

Table 2.6: INDOT HMA preventive maintenance treatment guidelines 12

Table 2.7: INDOT PCC preventive maintenance treatment guidelines 12

Table 2.8: Comparison of prioritization methods $\quad 22$

Table 4.1: Pavement attributes considered in study 29

Table 4.2: Pavement preservation and rehabilitation treatments considered in study 30

Table 4.3 Historical intervention levels for different pavement treatment categories 33

Table 4.4: Historical pavement maintenance and preservation treatment intervention levels 34

Table 4.5: Pavement M, R and R decision matrices 37

Table 4.6: Treatment selection matrices for asphalt pavements 39

Table 4.7: Treatment selection matrices for jointed or jointed-reinforced concrete pavements $\quad 40$

Table 4.8: Comparing Intervention Levels from Historical Decision and Expert Opinions 40

Table 4.9: Guidelines for Pavement Preservation Treatment Selection 41

Table 5.1: Regression Coefficients for Performance Models of Existing Pavements 45

Table 5.2: Short Term Effectiveness Models for Asphalt Preservation Treatments 47

Table 5.3: Short Term Effectiveness Models for PCC Preservation Treatments 48

Table 5.4: Long Term Performance Models for Preservation Treatments on Asphalt Pavements 49

Table 5.5: Cost for Pavement Repair and Rehabilitation Treatments 52

Table 5.6: Comparison of Selection Metric for Different Pavement Treatments 54 


\section{LIST OF FIGURES}

Figure $\quad$ Page

Figure 2.1: Pavement preservation concept 5

Figure 2.2: $\quad$ Example of a pavement option curve $\quad 6$

$\begin{array}{ll}\text { Figure 2.3: } & \text { Pavement preservation process }\end{array}$

Figure 2.4: Treatment strategy based on pavement condition 9

Figure 2.5: Deterioration reduction concept of measuring short-term effectiveness 14

Figure 2.6: Conceptual illustration of deterioration reduction rate 17

Figure 2.7: $\quad$ Illustration of pavement performance 19

Figure 3.1: Overview of study framework $\quad 25$

Figure 5.1: Illustration of performance jump and deterioration rate reduction 46

Figure 5.2: Computation of deterioration rate before treatment 47

Figure 5.3: Computation of remaining service life 50

Figure 5.4: Remaining service life approach for strategy selection 51

Figure 5.5: Comparison of preservation strategies on pavement performance 53

Figure 6.1: Pavement preservation planning within the pavement management system 56 framework

Figure 6.2: Candidate project selection $\quad 58$

Figure 6.3: $\quad$ Selecting optimal pavement preservation strategy 59

Figure 6.4: Candidate sections and their current conditions in the Excel spreadsheet 60

Figure 6.5: Optimal solution for feedback to central office 61

Figure 6.4: Distribution of pavement conditions in sample network 62

Figure 6.5: Optimal pavement strategy using proposed framework and "worst pavement first" 63 approach

Figure 6.6: RSLEs for proposed framework and "worst pavement first" approach 64 


\title{
CHAPTER 1: INTRODUCTION
}

\author{
$\underline{1.1 \quad \text { Background }}$
}

Deteriorating highway infrastructures has become one of the nation's major concerns. In 2009, the American Society of Civil Engineers has rated the nation's road infrastructures with a grade of D-minus. It was noted that Americans spend 4.2 billion hours a year stuck in traffic at $\$ 78.2$ billion (or $\$ 710$ per motorist) cost to the economy. Poor road conditions have cost motorists $\$ 67$ billion a year in repairs and operating costs, and cost 14,000 lives. One-third of the nation's major roads are in poor or mediocre condition and $36 \%$ of major urban highways are congested. The current federal spending level of $\$ 70.3$ billion per year for highway capital improvements is well below the estimated $\$ 186$ billion needed annually to substantially improve the nation's highways (ASCE, 2009).

Recognizing the severe challenges in maintaining our highway infrastructures, the concept of pavement preservation has been advocated by some as a plausible alternative to manage our road assets in a cost-effective manner. Pavement preservation can be broadly defined as "a planned system of treating pavements at the optimum time to maximize their useful life, thus enhancing the pavement longevity at the lowest cost" (Kuennen, 2005). In many places, pavement preservation calls for the use of preventive maintenance and minor rehabilitation treatments. This implies an intervention or treatment is carried out before distress has reached a level where the pavement's structural integrity has been compromised. Pavements which are left to deteriorate without timely preservation treatments are more likely to require major rehabilitation and reconstruction much sooner than those which are properly maintained. Experience have shown that spending $\$ 1$ on pavement preservation before the point of rapid deterioration eliminates or delays spending $\$ 6$ to $\$ 10$ on future rehabilitation or reconstruction costs (Kuennen, 2005). Pavement preservation therefore gives highway agencies an economical alternative in addressing pavement needs.

The pavement preservation concept, when applied at the network level, advocates the use of more frequent preservation treatments in lieu of major rehabilitation or reconstruction. This concept is analogous to the practices individual made when proactively maintaining their homes or automobiles in order to preserve the value of their assets. While individuals understand the importance of frequent maintenance to their homes and automobiles, the same concept are often, not applied to road 
infrastructure preservation. Most of the time, preservation only comes into the picture when pavements have deteriorated to an extent that traffic problems has occurred, which ironically means that the lesscostly preventive maintenance activities are no longer a viable alternative. Coupled with the budgetary constraints, many agencies have chosen to adopt a "worst first" approach, i.e. to fix the most serious and most obviously-deteriorated part of the network first. Many agencies have neglected the consideration of maintenance activities at network level programming, either due to a lack of information or believing that regular maintenance activities have little short or long term effects on pavement performance. In short, the pavement preservation approach requires the consideration of preventive maintenance treatments at the network level and also a shift in organizational mentality from a "worst-first" approach to one that sees value in the use of preservation treatments in improving the service lives of our highway infrastructure assets.

\subsection{Problem Statement and Study Objectives}

Over the years, the Indiana Department of Transportation (INDOT) has recognized the need to manage pavement effectively and efficiently. Numerous projects have been undertaken to evaluate pavement performance and to better manage the pavement maintenance and rehabilitation processes (Cullocis-Rio et al., 1984; Fwa and Sinha, 1985; Feighan et al., 1986; Fwa et al., 1988; Sinha et al., 1988; Mouaket et al., 1990; Lamptey et al., 2004, Sinha et al., 2005). These works have allowed the understanding of issues involved in maintenance and rehabilitation operations and the effects of these activities on pavement performance; and the ability and tools to better manage pavements at the network level (such as the optimal programming of maintenance and rehabilitation activities). These have no doubt improved INDOT's capabilities to manage pavements. However, there still needs to have a systematic framework that can integrate these ideas and tools to better preserve the pavements. Moreover, the framework should also revolve around the pavement preservation concept which advocates the pro-active planning and programming of preventive maintenance activities.

This research study therefore aims to develop a framework of pavement preservation program for INDOT that integrates the various components of pavement preservation at a district and network level. This includes: clearly differentiating preservation and rehabilitation activities, determining the effectiveness of preservation treatments, evaluation of pavement remaining life analysis of the pavement before and after the preservation treatment, and decision making tools to select pavement candidates for preservation treatments.

In short, the main objectives of this study are:

1. To assess current INDOT requirements for pavement preservation. 
2. To evaluate short and long term pavement performance for pavement preservation treatments.

3. To provide a framework for the determination of the remaining life evaluation of pavement before and after treatment and use it to compare strategies at the project level.

4. To provide a framework for the development of pavement preservation strategies at the district and network levels.

\section{$1.3 \quad$ Scope of Work}

The scope of work can be briefly summarized as follow:

- Review existing pavement preservation practices in the United States and in Indiana.

- Establish thresholds for pavement preservation treatments for INDOT use.

- Determine short and long term pavement performance models for selected pavement preservation treatments in Indiana.

- Illustrate the use of remaining service life for pavement preservation treatment comparison at the project level

- Develop a framework for INDOT to develop pavement preservation strategies at the network level.

\section{$1.4 \quad$ Report Outline}

This study report is divided into seven chapters. Chapter 1 briefly provides a background on pavement preservation, the issues involved, the need, objectives and scope of this research study. Chapter 2 presents a review of the existing literature related to the study of pavement preservation. Chapter 3 presents the study framework and the methodology adopted in the research study. Chapter 4 describes the development of thresholds or trigger values for pavement preservation treatments. Chapter 5 develops performance models for pavement preservation treatments and demonstrates the use of remaining service life in pavement treatment or strategy selection at the project level. Chapter 6 presents a framework that integrates the central office of state highway agencies to the individual district and develops an optimization model that districts can use to select the type of treatment to perform on a given section in the road network under their jurisdiction. Chapter 7 concludes the main findings of this report and provides recommendations for implementation and future research. 


\section{CHAPTER 2: EXISTING STATE OF PRACTICE IN PAVEMENT PRESERVATION}

An extensive review on the state of practice was first performed to assess the current state of practice and research in pavement preservation in the United States. The review was also extended to understand the various initiatives state highway agencies have taken to implement pavement preservation at a network level. Particular attention is also paid to the state of Indiana so that a customized pavement preservation framework can be developed.

\section{$2.1 \quad$ Definitions}

Before presenting the basic elements of a pavement preservation program and the current state of practice, some terms have to be first defined:

Asset Management - Asset management can be defined as a systematic process of maintaining, upgrading and operating physical assets cost-effectively (FHWA, 1999). Asset management is a business process and a decision-making framework that covers an extended time horizon, draws from economics as well as engineering principles, and considers a broad range of assets. The objective of the asset management program can be summarized as follows (Galehouse et al., 2003):

- Consider various investment strategies

- Provide a rational decision process

- Improve the overall condition of the highway system at a lower cost.

Preventive Maintenance - Preventive maintenance, as defined by AASHTO, is a planned strategy of cost-effective treatments to an existing roadway system and its appurtenances that preserves the system, retards future deterioration, and maintains or improves the functional condition of the system (without substantially increasing structural capacity). It is a tool for pavement preservation. Pavement preventive maintenance narrows that focus to the application of one or more treatments, generally to the surface of a structurally sound roadway. Preventive maintenance is associated with the application of the right non-structural treatments to the right pavement at the right time. 
Pavement Preservation - Pavement preservation is the sum of all activities undertaken to provide and maintain serviceable roadways; this includes corrective maintenance and preventive maintenance, as well as minor rehabilitation projects. It excludes new or reconstructed pavements and pavements requiring major rehabilitation or reconstruction. Pavement preservation is a program of activities aimed at preserving investment in the highway system, extending pavement life, enhancing pavement performance, ensuring cost effectiveness, and reducing user delays - in short, meeting the users' needs. This is all part of the bigger picture of transportation system preservation.

Reactive Maintenance - Reactive maintenance comprises of activities that respond to situations beyond the agency's control, activities such as pothole patching, rut filling or unplugging drainage facilities. Reactive maintenance is unscheduled and sometimes requires immediate response to avoid serious consequences.

Emergency Maintenance - Extreme conditions when life and property are at risk would require emergency maintenance. Examples of such extreme conditions include washouts, rigid pavement blowups, rockslides and earth slides.

\subsection{A Generic Framework for Pavement Preservation}

Pavement preservation is a network level, long term strategy that enhances pavement performance by using a variety of cost-effective surface treatments that extend pavement life. These treatments must be carefully selected and applied before the pavement sustains structural damage. Figure 2.1 shows a depiction on the pavement preservation concept. It can be seen that pavement preservation comprises of a series of preventive and corrective maintenance as well as minor rehabilitation. Through the use of more frequent preservation treatments, a better pavement performance can be achieved.

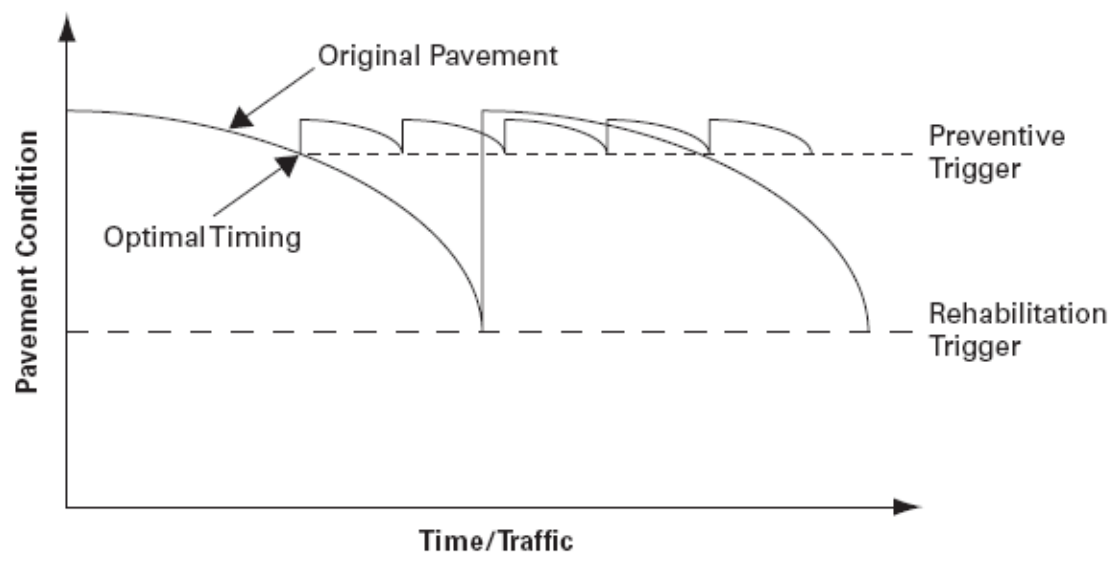

Figure 2.1: Pavement preservation concept 
Table 2.1 defines pavement preservation and compares it against reconstruction and major rehabilitation. It is clearly noted in the table that pavement preservation activities restore the functional aspects (i.e. reduce aging and restore serviceability) of the existing pavements and extend its service life, but does not increase the structural capacity or the strength. This has the implication of determining the optimal timing to apply pavement preservation treatments, as these treatments are not meant to restore structural capacity or improve the structural strength of the pavements.

Table 2.1: Pavement Preservation Guidelines

\begin{tabular}{|c|c|c|c|c|c|}
\hline & Type of Activity & $\begin{array}{l}\text { Increase } \\
\text { Capacity }\end{array}$ & $\begin{array}{l}\text { Increase } \\
\text { Strength }\end{array}$ & $\begin{array}{l}\text { Reduce } \\
\text { Aging }\end{array}$ & $\begin{array}{l}\text { Restore } \\
\text { Serviceability }\end{array}$ \\
\hline & New Construction & $\mathrm{X}$ & $\mathrm{X}$ & $\mathrm{X}$ & $\mathrm{X}$ \\
\hline & Reconstruction & $\mathrm{X}$ & $\mathrm{X}$ & $\mathrm{X}$ & $\mathrm{X}$ \\
\hline & $\begin{array}{l}\text { Major (Heavy) } \\
\text { Rehabilitation } \\
\end{array}$ & & $\mathrm{X}$ & $\mathrm{X}$ & $\mathrm{X}$ \\
\hline & Structural Overlay & & $\mathrm{X}$ & $\mathrm{X}$ & $\mathrm{X}$ \\
\hline \multirow{5}{*}{$\begin{array}{l}\text { Pavement } \\
\text { Preservation }\end{array}$} & Minor (Light) Rehabilitation & & & $\mathrm{X}$ & $\mathrm{X}$ \\
\hline & Preventive Maintenance & & & $\mathrm{X}$ & $\mathrm{X}$ \\
\hline & Routine Maintenance & & & & $\mathrm{X}$ \\
\hline & $\begin{array}{l}\text { Corrective (Reactive) } \\
\text { Maintenance }\end{array}$ & & & & $\mathrm{X}$ \\
\hline & Emergency Maintenance & & & & $\mathrm{X}$ \\
\hline
\end{tabular}

Often, the benefits of implementing a pavement preservation program are not immediate and dramatic (compared to rehabilitation and reconstruction) but accrue with time. Roads that are of good condition do not register a major change in condition rating after a treatment is applied. The important thing is that roads that received preservation treatments are in a better condition than those left without treatments after several years. This is best depicted in Figure 2.2 where the agency has to consider the options of either spending on preservation or waiting until rehabilitation or reconstruction at the end of service life. In this case, typical economic analytical approaches such as the life cycle cost analysis or the benefit-cost analysis have been used by past researchers (Galehouse et al., 2003).

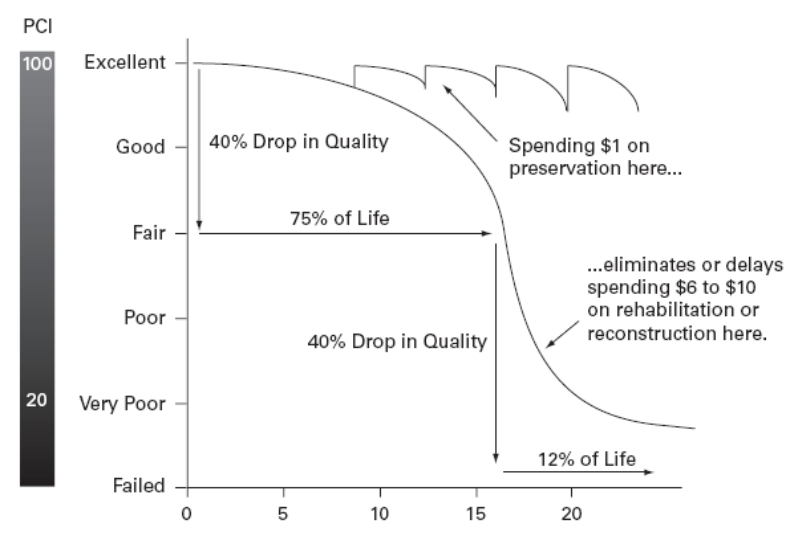

Figure 2.2: Example of a pavement option curve (PCI = Pavement Condition Index $)$ 
A generic framework of the pavement preservation program was proposed by Galehouse et al. (2003) (Figure 2.3). For the program to be effective, almost every part of the agency has to be involved. Galehouse et al. (2003) noted that the success of the program is dependent on the level of support and the input from staff in planning, finance, design, construction, materials and maintenance. Two other essentials would include the long-term commitment of the agency and a dedicated annual budget for the pavement preservation program. Also the framework highlights the need to address several issues before the implementation of the program. For example, the terminology has to be clearly defined and the issues on the optimal timing, cost-effectiveness and pavement performance for different treatments on different pavement types has to be established. Integrating pavement management with pavement preservation is also imperative, in order to maximize the benefits to the highway network. Furthermore, staff must also be trained about each preservation treatment and its appropriate use.

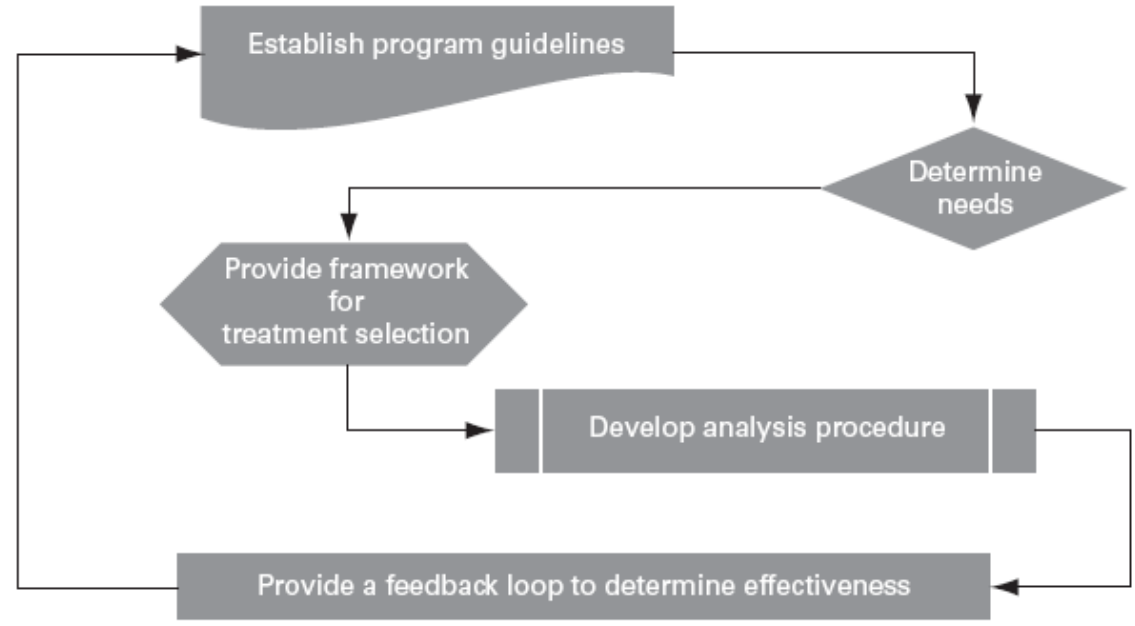

Figure 2.3: Pavement preservation process

It is noted from Figure 2.3 that there is a need to develop guidelines that relate to the various pavement conditions, the purpose and the limitations of each preservation treatment, and also the expected performance after applying a treatment. This information will aid in the development of the guidelines for treatment selection and program assessment. It is further noted that a good pavement preservation program should also establish a system of continual monitoring and ensure an effective feedback to improve the developed guidelines.

FHWA (2005) further suggested the following guidelines for agencies who desired to start a pavement preservation program. These can be summarized as follows:

- Inventory road system and components - This provides the starting point of the pavement preservation program. It is desired that there is available data or a system in place to gather data 
on the average daily traffic (ADT) and the equivalent single axle load (ESAL) on roads that have heavier traffic, or is expecting a lot of growth, or have not been surveyed for a while.

- Field survey to determine pavement conditions - These are necessary inputs to the pavement condition index, or any other form of index that can describe the condition and the serviceability of the pavement. These will provide the data needed for treatment selection and prioritization.

- Analyze field surveys and reports to determine maintenance strategies - This step is needed to develop treatment strategies for the pavements. Pavements that are severely distressed may not be the best candidates for treatment as a reconstruction can be scheduled very soon. Instead it is better to perform treatments on lightly or moderately distressed pavements.

- Plan strategy using analysis from pavement management concepts - A pavement management system is needed for decision making, especially at the network level.

- Implement, execute and document costs and work performed for future use - By keeping track of the work performed and the cost involved, the life of the pavement and the true costs can be determined.

\section{3 Pavement Preservation Treatments Selection Guidelines}

One of the most important elements of a pavement preservation program is the establishment of proper pavement preservation guidelines. By properly identifying pavements that are ideal for pavement preservation (i.e. pavements that do not have structural damage), it avoids wasteful spending of resources on treatment that only provides minimal extension in service life. Zimmerman and Peshkin (2004) provided a rough classification of pavement preservation treatments adopted by various state highway agencies (Table 2.2). Many agencies have also further expanded their definition of pavement preservation to include cold-in-place recycling and hot-in-place recycling for asphalt pavements, and various patching and full-depth repair strategies for concrete pavements.

Table 2.2: Types of pavement preservation techniques

\begin{tabular}{ll}
\hline Asphalt Pavements & Concrete Pavements \\
\hline Thin hot-mix overlays (less than 1.5 to 2 in.) & Crack and joint sealing \\
Mill and fill operations & Diamond grinding \\
Crack treatments & Diamond grooving \\
Microsurfacing & Undersealing \\
Chip seals & Load transfer restriction \\
Fog seals & Maintenance of drainage features \\
Slurry seals & \\
Ultrathin friction course & \\
Maintenance of drainage features & \\
\hline
\end{tabular}


In terms of treatment selection guidelines, there exist many factors that can affect the selection of an appropriate treatment for a pavement. These include pavement age, condition, traffic levels, expected future plans, as well as available funding and agency policy. At the network level, a general relationship exists between pavement condition and pavement age. For a properly constructed new pavement, the only treatments that are required are preventive maintenance or preservation (performed to delay the onset of distress). Then, as the pavement ages, it may become a candidate for routine maintenance or preservation (crack sealing or chip sealing), rehabilitation and eventually reconstruction. Figure 2.4 illustrates some of the treatment strategies that can be employed based on the condition index of the existing pavement.

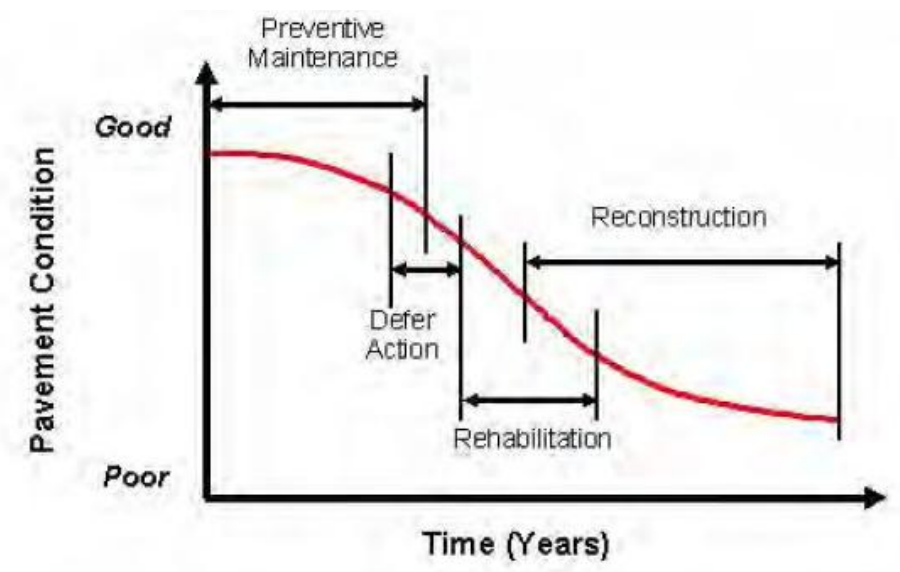

Figure 2.4: Treatment strategy based on pavement condition

When developing treatment selection guidelines, the typical procedures used to select appropriate treatments include (Uddin, 2006):

- "ad-hoc" based on past experience, subjective judgment, or personal preference,

- based upon distress type and severity, such as the PAVER procedure,

- use of a composite index; for example, PCR as a function of distress attributes and IRI,

- calculation of the life-cycle costs and benefits considering roughness and distress attributes for interventional levels and selection of the most economical one,

- a decision tree approach considering all distress type and other condition attributes, and

- application of modern artificial intelligence technologies (expert system, fuzzy set, ANN).

Many limitations can be identified with some of the above procedures. The traditional ad hoc policy was the norm before PMS concepts were developed. The use of one or more composite index in some current PMS programs is oversimplification; it misses the mechanism leading to condition deterioration and, therefore, results in an inappropriate maintenance treatment. The use of life cycle costs and benefits may be useful in providing cost-effective solutions, but a great deal of time and effort is required to quantify 
performance and life cycle behavior of preservation treatments. To date, the decision tree/matrix approach is probably the most popular approach, but this method can become extremely complex when more condition attributes are considered.

Many state DOTs have also developed their own treatment selection guidelines. For example, Caltrans has developed a comprehensive treatment selection matrix based on pavement conditions (rutting, cracking, raveling, oxidization and bleeding), climate, traffic volumes, type of highway and others. Table 2.3 describes the selection of preservation treatments for asphalt pavements based on these factors while Table 2.4 shows the same for PCC pavements (Caltrans, 2002; 2006). In a similar fashion, FHWA (2005) also developed a set of preservation treatment selection guidelines for asphalt pavements, taking into account of pavement surface distresses, skid resistance, highway functional class and others. The ACPA has also provided a set of selection guidelines for activating preservation treatments on PCC pavements (Table 2.5) (ACPA, 1998). It can be observed from Tables 2.3 to 2.5 that the developed guidelines are primarily expert-opinion based and are in the form of decision matrices or trees.

Table 2.3: Caltrans asphalt pavement preservation treatment selection guidelines (Caltrans, 2002)

\begin{tabular}{|c|c|c|c|c|c|c|c|c|c|c|c|c|c|c|c|c|c|c|c|c|c|c|c|c|c|}
\hline \multirow[b]{3}{*}{ Treatment } & \multicolumn{10}{|c|}{ Pavement Condition } & \multicolumn{15}{|c|}{ Parameters } \\
\hline & \multirow[b]{2}{*}{$\begin{array}{l}\stackrel{\infty}{\Xi} \\
\stackrel{0}{ \pm} \\
\stackrel{\Xi}{\approx}\end{array}$} & \multirow[b]{2}{*}{ 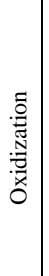 } & \multirow[b]{2}{*}{$\begin{array}{l}\stackrel{\infty}{\Xi} \\
: 0 \\
\stackrel{D}{ \pm} \\
\infty\end{array}$} & \multicolumn{2}{|c|}{ Rutting } & \multicolumn{5}{|c|}{ Cracking } & \multicolumn{4}{|c|}{ Climate } & \multicolumn{3}{|c|}{$\begin{array}{c}\text { Traffic } \\
\text { Volume }\end{array}$} & \multirow[b]{2}{*}{ 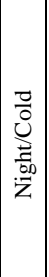 } & \multirow[b]{2}{*}{ 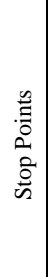 } & \multirow[b]{2}{*}{ 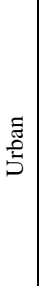 } & \multirow[b]{2}{*}{ 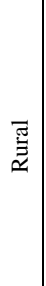 } & \multirow{2}{*}{ 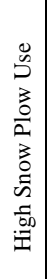 } & \multirow{2}{*}{ 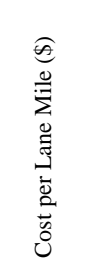 } & \multirow{2}{*}{ 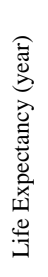 } & \multirow{2}{*}{ 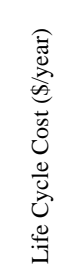 } \\
\hline & & & & $\stackrel{\grave{V}}{\vec{V}}$ & $\stackrel{\hat{\wedge}}{\stackrel{\wedge}{\wedge}}$ & $\begin{array}{l}80 \\
0 \\
0 \\
0\end{array}$ & $\begin{array}{l}\stackrel{0}{0} \\
\text { i } \\
\stackrel{0}{0} \\
0\end{array}$ & $\begin{array}{c}80 \\
0 \\
m \\
0 \\
0 \\
0 \\
0\end{array}$ & 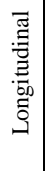 & 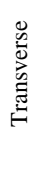 & 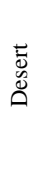 & $\frac{\partial}{\stackrel{\partial}{J}}$ & 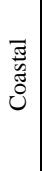 & $\begin{array}{l}\stackrel{\Xi}{\stackrel{\Xi}{\Xi}} \\
\stackrel{\Xi}{\Xi}\end{array}$ & 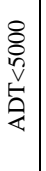 & 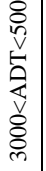 & 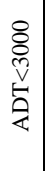 & & & & & & & & \\
\hline \multicolumn{26}{|l|}{ Crack/Joint Seal } \\
\hline Emulsion & $\mathrm{N}$ & $\mathrm{N}$ & $\mathrm{N}$ & $\mathrm{N}$ & $\mathrm{N}$ & $\mathrm{F}$ & $\mathrm{P}$ & $\mathrm{N}$ & $\mathrm{F}$ & $\mathrm{F}$ & $\mathrm{G}$ & $\mathrm{G}$ & $\mathrm{G}$ & $\mathrm{G}$ & $\mathrm{G}$ & $\mathrm{G}$ & $\mathrm{G}$ & $\mathrm{N}$ & $\mathrm{G}$ & $\mathrm{G}$ & $\mathrm{G}$ & $\mathrm{G}$ & 2,500 & $1-2$ & 1,700 \\
\hline Modified (Rubber) & $\mathrm{N}$ & $\mathrm{N}$ & $\mathrm{N}$ & $\mathrm{N}$ & & $\mathrm{G}$ & $\mathrm{G}$ & $\mathrm{G}$ & $\mathrm{G}$ & $\mathrm{G}$ & $\mathrm{G}$ & $\mathrm{G}$ & $\mathrm{G}$ & $\mathrm{G}$ & $\mathrm{G}$ & $\mathrm{G}$ & $\mathrm{G}$ & $\mathrm{G}$ & $\mathrm{G}$ & $\mathrm{G}$ & $\mathrm{G}$ & $\mathrm{G}$ & 2,500 & $2-3$ & 1,000 \\
\hline \multicolumn{26}{|l|}{ Polymer and Asphalt } \\
\hline Fog Seal & $\mathrm{F}$ & $\mathrm{G}$ & $\mathrm{N}$ & $\mathrm{N}$ & $\mathrm{N}$ & $\mathrm{F}$ & $\mathrm{P}$ & $\mathrm{N}$ & $\mathrm{P}$ & $\mathrm{P}$ & $\mathrm{G}$ & $\mathrm{G}$ & $\mathrm{G}$ & $\mathrm{G}$ & $\mathrm{F}$ & $\mathrm{N}$ & $\mathrm{N}$ & $\mathrm{P}$ & $\mathrm{F}$ & $\mathrm{G}$ & $\mathrm{G}$ & $\mathrm{F}$ & 4,500 & 1 & 4,500 \\
\hline Rejuvenator & $\mathrm{G}$ & $\mathrm{G}$ & $\mathrm{N}$ & $\mathrm{N}$ & $\mathrm{N}$ & $\mathrm{F}$ & $\mathrm{N}$ & $\mathrm{N}$ & $\mathrm{N}$ & $\mathrm{N}$ & $\mathrm{G}$ & $\mathrm{G}$ & $\mathrm{G}$ & $\mathrm{G}$ & $\mathrm{G}$ & $\mathrm{F}$ & $\mathrm{N}$ & $\mathrm{N}$ & $\mathrm{N}$ & $\mathrm{G}$ & $\mathrm{F}$ & $\mathrm{F}$ & 4,500 & $2-4$ & 4,500 \\
\hline \multicolumn{26}{|l|}{ Slurry Seal } \\
\hline Type II & $\mathrm{F}$ & $\mathrm{G}$ & $\mathrm{N}$ & $\mathrm{N}$ & $\mathrm{N}$ & $\mathrm{F}$ & $\mathrm{N}$ & $\mathrm{N}$ & $\mathrm{N}$ & $\mathrm{N}$ & $\mathrm{G}$ & $\mathrm{G}$ & $\mathrm{G}$ & $\mathrm{F}$ & $\mathrm{G}$ & $\mathrm{G}$ & $\mathrm{G}$ & $\mathrm{P}$ & $\mathrm{G}$ & $\mathrm{G}$ & $\mathrm{G}$ & $\mathrm{P}$ & 13,000 & $3-4$ & 3,700 \\
\hline Type III & $\mathrm{G}$ & $\mathrm{G}$ & $\mathrm{N}$ & $\mathrm{F}$ & $\mathrm{N}$ & $\mathrm{F}$ & $\mathrm{P}$ & $\mathrm{N}$ & $\mathrm{N}$ & $\mathrm{N}$ & $\mathrm{G}$ & $\mathrm{G}$ & $\mathrm{G}$ & $\mathrm{F}$ & $\mathrm{G}$ & $\mathrm{G}$ & $\mathrm{G}$ & $\mathrm{N}$ & $\mathrm{G}$ & $\mathrm{G}$ & $\mathrm{G}$ & \begin{tabular}{l|l}
$\mathrm{P}$ \\
\end{tabular} & 13,000 & $3-4$ & 3,700 \\
\hline Microsurfacing & & & & & & & & & & & & & & & & & & & & & & & & & \\
\hline Type II & $\mathrm{G}$ & $\mathrm{G}$ & $\mathrm{N}$ & $\mathrm{G}$ & $\mathrm{N}$ & $\mathrm{F}$ & $\mathrm{N}$ & $\mathrm{N}$ & $\mathrm{N}$ & $\mathrm{N}$ & $\mathrm{G}$ & $\mathrm{G}$ & $\mathrm{G}$ & $\mathrm{G}$ & $\mathrm{G}$ & $\mathrm{G}$ & $\mathrm{G}$ & $\mathrm{F}$ & $\mathrm{G}$ & $\mathrm{G}$ & $\mathrm{G}$ & $\mathrm{F}$ & 16,000 & $3-4$ & 4,500 \\
\hline Type III & $\mathrm{G}$ & $\mathrm{G}$ & $\mathrm{N}$ & $\mathrm{G}$ & $\mathrm{G}$ & $\mathrm{F}$ & $\mathrm{P}$ & $\mathrm{N}$ & $\mathrm{N}$ & $\mathrm{N}$ & $\mathrm{G}$ & $\mathrm{G}$ & $\mathrm{G}$ & $\mathrm{G}$ & $\mathrm{G}$ & $\mathrm{G}$ & $\mathrm{G}$ & $\mathrm{F}$ & $\mathrm{G}$ & $\mathrm{G}$ & $\mathrm{G}$ & $\mathrm{F}$ & 16,000 & $3-4$ & 4,500 \\
\hline Chip Seal & & & & & & & & & & & & & & & & & & & & & & & & & \\
\hline PME - Med. Fine & $\mathrm{G}$ & $\mathrm{G}$ & $\mathrm{N}$ & $\mathrm{F}$ & $\mathrm{N}$ & $\mathrm{G}$ & $\mathrm{F}$ & $\mathrm{N}$ & $\mathrm{P}$ & $\mathrm{P}$ & G & $\mathrm{G}$ & $\mathrm{F}$ & $\mathrm{F}$ & $\mathrm{G}$ & $\mathrm{G}$ & $\mathrm{N}$ & $\mathrm{N}$ & $\mathrm{P}$ & $\mathrm{P}$ & $\mathrm{G}$ & $\mathrm{P}$ & 6,500 & $1-5$ & 1,600 \\
\hline PME - Medium & $\mathrm{G}$ & $\mathrm{G}$ & $\mathrm{N}$ & $\mathrm{F}$ & $\mathrm{N}$ & $\mathrm{G}$ & $\mathrm{F}$ & $\mathrm{N}$ & $\mathrm{P}$ & $\mathrm{P}$ & $\mathrm{G}$ & $\mathrm{G}$ & $\mathrm{F}$ & $\mathrm{F}$ & $\mathrm{G}$ & $\mathrm{N}$ & $\mathrm{N}$ & $\mathrm{N}$ & $\mathrm{P}$ & $\mathrm{P}$ & $\mathrm{G}$ & $\mathrm{F}$ & 6,500 & $1-5$ & 1,600 \\
\hline PMA - Medium & $\mathrm{G}$ & $\mathrm{G}$ & $\mathrm{N}$ & $\mathrm{F}$ & $\mathrm{N}$ & $\mathrm{G}$ & $\mathrm{F}$ & $\mathrm{P}$ & $\mathrm{P}$ & $\mathrm{P}$ & $\mathrm{G}$ & $\mathrm{G}$ & $\mathrm{G}$ & $\mathrm{G}$ & $\mathrm{G}$ & $\mathrm{N}$ & $\mathrm{G}$ & $\mathrm{N}$ & $\mathrm{P}$ & $\mathrm{P}$ & $\mathrm{G}$ & $\mathrm{F}$ & 12,500 & $4-5$ & 2,800 \\
\hline PMA - Coarse & $\mathrm{G}$ & $\mathrm{G}$ & $\mathrm{N}$ & $\mathrm{F}$ & $\mathrm{N}$ & $\mathrm{G}$ & $\mathrm{F}$ & $\mathrm{P}$ & $\mathrm{P}$ & $\mathrm{P}$ & $\mathrm{G}$ & $\mathrm{G}$ & $\mathrm{G}$ & $\mathrm{G}$ & $\mathrm{N}$ & $\mathrm{N}$ & $\mathrm{G}$ & $\mathrm{N}$ & $\mathrm{P}$ & $\mathrm{P}$ & $\mathrm{G}$ & $\mathrm{G}$ & 12,500 & $4-5$ & 2,800 \\
\hline AR - Medium & $\mathrm{G}$ & $\mathrm{G}$ & $\mathrm{N}$ & $\mathrm{F}$ & $\mathrm{N}$ & $\mathrm{G}$ & $\mathrm{G}$ & $\mathrm{F}$ & $\mathrm{P}$ & $\mathrm{P}$ & $\mathrm{G}$ & $\mathrm{G}$ & $\mathrm{G}$ & $\mathrm{G}$ & $\mathrm{G}$ & $\mathrm{N}$ & $\mathrm{G}$ & $\mathrm{N}$ & $\mathrm{P}$ & $\mathrm{P}$ & $\mathrm{G}$ & $\mathrm{F}$ & 20,000 & $4-6$ & 4,000 \\
\hline AR - Coarse & $\mathrm{G}$ & $\mathrm{G}$ & $\mathrm{N}$ & $\mathrm{F}$ & $\mathrm{N}$ & $\mathrm{G}$ & $\mathrm{G}$ & $\mathrm{F}$ & $\mathrm{P}$ & $\mathrm{P}$ & $\mathrm{G}$ & $\mathrm{G}$ & $\mathrm{G}$ & $\mathrm{G}$ & $\mathrm{N}$ & $\mathrm{N}$ & $\mathrm{G}$ & $\mathrm{N}$ & $\mathrm{P}$ & \begin{tabular}{l|l}
$\mathrm{P}$ \\
\end{tabular} & $\mathrm{G}$ & $\mathrm{G}$ & 20,000 & $4-6$ & 4,000 \\
\hline PM Alternative & & & & & & & & & & & & & & & & & & & & & & & & & \\
\hline Conventional OGAC & $\mathrm{G}$ & $\mathrm{G}$ & $\mathrm{P}$ & $\mathrm{P}$ & $\mathrm{N}$ & $\mathrm{G}$ & $\mathrm{F}$ & $\mathrm{N}$ & $\mathrm{P}$ & $\mathrm{P}$ & $\mathrm{G}$ & $\mathrm{G}$ & $\mathrm{G}$ & $\mathrm{G}$ & $\mathrm{G}$ & $\mathrm{G}$ & $\mathrm{G}$ & $\mathrm{P}$ & $\mathrm{G}$ & $\mathrm{G}$ & $\mathrm{G}$ & $\mathrm{O}$ & 19,500 & $3-4$ & 5,600 \\
\hline PBA OGAC4 & $\mathrm{G}$ & $\mathrm{G}$ & $\mathrm{P}$ & $\mathrm{P}$ & $\mathrm{N}$ & $\mathrm{G}$ & $\mathrm{F}$ & $\mathrm{N}$ & $\mathrm{P}$ & $\mathrm{P}$ & $\mathrm{G}$ & $\mathrm{G}$ & $\mathrm{G}$ & $\mathrm{G}$ & $\mathrm{G}$ & $\mathrm{G}$ & $\mathrm{G}$ & $\mathrm{F}$ & $\mathrm{G}$ & $\mathrm{G}$ & $\mathrm{G}$ & $\mathrm{P}$ & 25,000 & $4-5$ & 5,600 \\
\hline AR (Type O) & $\mathrm{G}$ & $\mathrm{G}$ & \begin{tabular}{l|l}
$\mathrm{P}$ & \\
\end{tabular} & $\mathrm{F}$ & $\mathrm{N}$ & $\mathrm{G}$ & $\mathrm{G}$ & $\mathrm{F}$ & $\mathrm{P}$ & $\mathrm{P}$ & $\mathrm{G}$ & $\mathrm{G}$ & $\mathrm{G}$ & $\mathrm{G}$ & $\mathrm{G}$ & $\mathrm{G}$ & $\mathrm{G}$ & $\mathrm{P}$ & $\mathrm{G}$ & $\mathrm{G}$ & $\mathrm{G}$ & $\mathrm{P}$ & 28,000 & $4-6$ & 5,600 \\
\hline Thin Asphalt Overlay & & & & & & & & & & & & & & & & & & & & & & & & & \\
\hline Conventional & $\mathrm{G}$ & $\mathrm{G}$ & \begin{tabular}{l|l} 
\\
\end{tabular} & $\mathrm{G}$ & $\mathrm{G}$ & $\mathrm{G}$ & $\mathrm{G}$ & $\mathrm{F}$ & $\mathrm{P}$ & $\mathrm{P}$ & $\mathrm{G}$ & $\mathrm{G}$ & $\mathrm{G}$ & $\mathrm{G}$ & $\mathrm{G}$ & $\mathrm{G}$ & $\mathrm{G}$ & $\mathrm{G}$ & $\mathrm{G}$ & $\mathrm{G}$ & $\mathrm{G}$ & $\mathrm{G}$ & 20,000 & $3-5$ & 5,000 \\
\hline PBA & $\mathrm{G}$ & $\mathrm{G}$ & $\mathrm{P}$ & $\mathrm{G}$ & $\mathrm{G}$ & $\mathrm{G}$ & $\mathrm{G}$ & $\mathrm{G}$ & $\mathrm{F}$ & $\mathrm{F}$ & $\mathrm{G}$ & $\mathrm{G}$ & $\mathrm{G}$ & $\mathrm{G}$ & $\mathrm{G}$ & $\mathrm{G}$ & $\mathrm{G}$ & $\mathrm{G}$ & $\mathrm{G}$ & $\mathrm{G}$ & $\mathrm{G}$ & $\mathrm{G}$ & 25,000 & $3-6$ & 5,000 \\
\hline R (Type G) & $\mathrm{G}$ & $\mathrm{G}$ & $\mathrm{P}$ & $\mathrm{G}$ & $\mathrm{G}$ & $\mathrm{G}$ & $\mathrm{G}$ & $\mathrm{G}$ & $\mathrm{G}$ & $\mathrm{G}$ & $\mathrm{G}$ & $\mathrm{G}$ & $\mathrm{G}$ & $\mathrm{G}$ & $\mathrm{G}$ & $\mathrm{G}$ & $\mathrm{G}$ & $\mathrm{F}$ & $\mathrm{G}$ & $\mathrm{G}$ & $\mathrm{G}$ & $\mathrm{G}$ & 30,000 & $5-8$ & 4,600 \\
\hline Dig-outs & $\mathrm{P}$ & $\mathrm{P}$ & $\mathrm{G}$ & $\mathrm{N}$ & $\mathrm{G}$ & $\mathrm{N}$ & $\mathrm{N}$ & $\mathrm{G}$ & $\mathrm{P}$ & $\mathrm{P}$ & $\mathrm{G}$ & $\mathrm{G}$ & $\mathrm{G}$ & $\mathrm{G}$ & $\mathrm{G}$ & $\mathrm{G}$ & $\mathrm{G}$ & $\mathrm{F}$ & $\mathrm{G}$ & $\mathrm{G}$ & $\mathrm{G}$ & $\mathrm{G}$ & 19,000 & $5-8$ & 2,900 \\
\hline
\end{tabular}


Table 2.4: Caltrans PCC Pavement Preservation Treatment Selection Guidelines (Caltrans, 2006)

\begin{tabular}{|c|c|c|c|c|c|c|c|c|c|c|}
\hline \multirow[t]{2}{*}{ Treatment } & \multirow[t]{2}{*}{ Trigger } & \multicolumn{4}{|c|}{ Climate } & \multicolumn{3}{|c|}{ Traffic ADT } & \multirow[b]{2}{*}{ 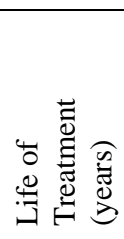 } & \multirow[b]{2}{*}{ 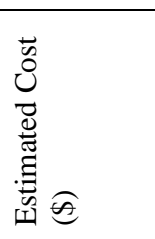 } \\
\hline & & 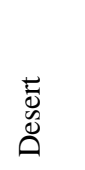 & 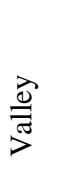 & 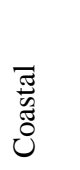 & 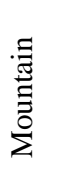 & $\begin{array}{l}8 \\
8 \\
\wp \\
\vee\end{array}$ & $\begin{array}{l}8 \\
8 \\
8 \\
\text { ఝ } \\
8 \\
8 \\
\text { in }\end{array}$ & 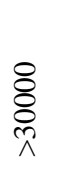 & & \\
\hline Crack Resealing & $>1 / 8$ inch & $>1 / 4$ & $>1 / 8$ & $>1 / 8$ & $>1 / 4$ & $>1 / 2$ & $>1 / 4$ & $>1 / 8$ & $5-10$ & $\begin{array}{l}\$ 27.7 \mathrm{k}- \\
42.4 \mathrm{k} / \mathrm{ln}-\mathrm{mi}\end{array}$ \\
\hline Diamond Grinding & $\begin{array}{l}\text { Faulting }>1 / 8 \text { inch } \\
\text { Ride } 95 \text { in } / \text { mile }\end{array}$ & $\begin{array}{c}>1 / 4 \\
190\end{array}$ & $\begin{array}{c}>1 / 8 \\
95\end{array}$ & $\begin{array}{c}>1 / 8 \\
95\end{array}$ & $\begin{array}{c}>1 / 4 \\
190\end{array}$ & $\begin{array}{c}>1 / 4 \\
190\end{array}$ & $\begin{array}{l}>1 / 8 \\
125\end{array}$ & $\begin{array}{c}>1 / 8 \\
95\end{array}$ & $10-18$ & $\begin{array}{l}\text { \$30.0k- } \\
80.1 \mathrm{k} / \mathrm{ln}-\mathrm{mi}\end{array}$ \\
\hline Partial Slab Repair & $\begin{array}{l}\text { Surface distress } \\
\text { Patches }<1.2 \mathrm{yd}^{2}\end{array}$ & $<1 / 2$ & $<1 / 2$ & $<1 / 2$ & $<2.4$ & $<2.4$ & $<1 / 2$ & $<1 / 2$ & $8-10$ & $\begin{array}{l}\$ 135- \\
270 / \mathrm{yd}^{2}\end{array}$ \\
\hline $\begin{array}{l}\text { Isolated Slab } \\
\text { Repair }\end{array}$ & $\begin{array}{l}3^{\text {rd }} \text { stage cracking } \\
\text { or unstable slabs }\end{array}$ & \multicolumn{7}{|c|}{$\begin{array}{l}\text { Same trigger value. For desert, mountain or ADT }<500 \text {, } \\
\text { district makes decision to repair. }\end{array}$} & $8-15$ & $\$ 4 \mathrm{k}-8 \mathrm{k} / \mathrm{slab}$ \\
\hline Dowel Bar Retrofit & $\begin{array}{l}\text { LTE }<60 \% \\
\text { Faulting }>0.1 \text { inch } \\
\text { Max } 10 \% \text { cracking }\end{array}$ & $\begin{array}{c}<40 \\
>1 / 4 \\
20\end{array}$ & $\begin{array}{c}<70 \\
>1 / 8 \\
10\end{array}$ & $\begin{array}{c}<70 \\
>1 / 8 \\
10\end{array}$ & $\begin{array}{c}<50 \\
>1 / 4 \\
20\end{array}$ & $\begin{array}{c}<50 \\
>1 / 4 \\
20\end{array}$ & $\begin{array}{c}<70 \\
>1 / 8 \\
10\end{array}$ & $\begin{array}{c}<70 \\
>1 / 8 \\
10\end{array}$ & $8-15$ & $\begin{array}{l}\text { \$141k- } \\
177 \mathrm{k} / \mathrm{ln}-\mathrm{mi}\end{array}$ \\
\hline
\end{tabular}

Table 2.5: ACPA Jointed PCC Pavement Preservation Treatment Selection Guidelines (ACPA, 1998)

\begin{tabular}{|c|c|c|c|}
\hline $\begin{array}{c}\text { Jointed PCCP } \\
\text { (Joint Spacing }<6 \mathrm{~m} \text {, slab width } 4.5 \mathrm{~m} \text { ) }\end{array}$ & \multicolumn{3}{|c|}{ Trigger/Limit Values } \\
\hline Traffic Volumes & $\begin{array}{c}\text { High } \\
(\mathrm{ADT}>10,000)\end{array}$ & $\begin{array}{c}\text { Medium } \\
(3,000<\text { ADT }<10,000)\end{array}$ & $\begin{array}{c}\text { Low } \\
(\mathrm{ADT}<3,000)\end{array}$ \\
\hline \multicolumn{4}{|l|}{ Structural Measurements } \\
\hline Low to high severity fatigue cracking (\% of slabs) & $1.5 / 5.0$ & $2.0 / 10.0$ & $2.5 / 15.0$ \\
\hline Deteriorated joints (\% of joints) & $1.5 / 15.0$ & $2.0 / 17.5$ & $2.5 / 20.0$ \\
\hline Corner breaks (\% of joints) & $1.0 / 8.0$ & $1.5 / 10.0$ & $2.0 / 12.0$ \\
\hline Faulting (average $\mathrm{mm}$ ) & $2.0 / 12.0$ & $2.0 / 15.0$ & $2.0 / 18.0$ \\
\hline Durability Distress (severity) & \multicolumn{3}{|c|}{ Medium-High } \\
\hline Joint seal damage (\% of joints) & \multicolumn{3}{|c|}{$>25 /-$} \\
\hline Load transfer $(\%)$ & \multicolumn{3}{|c|}{$<50 /-$} \\
\hline Skid resistance & \multicolumn{3}{|c|}{ Minimum local acceptable level } \\
\hline \multicolumn{4}{|l|}{ Functional Measurements } \\
\hline IRI $(\mathrm{m} / \mathrm{km})$ & $1.0 / 2.5$ & $1.2 / 3.0$ & $1.4 / 3.5$ \\
\hline PSR & $3.8 / 3.0$ & $3.6 / 2.5$ & $3.4 / 2.0$ \\
\hline California profilograph & $12 / 60$ & $15 / 80$ & $18 / 100$ \\
\hline
\end{tabular}

Similar guidelines are also adopted in Indiana. Tables 2.6 and 2.7 show the preventive maintenance guidelines adopted by INDOT for asphalt and PCC pavements respectively (INDOT, 2009). In general, for asphalt pavements, preventive maintenance treatments are applied to pavements with IRI less than $150 \mathrm{in} / \mathrm{mi}$ and low to moderate cracks. For PCC pavements, preventive maintenance treatments are applied to pavements with significant surface distresses (e.g. cracks, sealant damage, faulting. It is noted especially that for PCC pavements, guidelines based on IRI or friction are never explicitly stated. 
Table 2.6: INDOT HMA Preventive Maintenance Treatment Guidelines (INDOT, 2009)

\begin{tabular}{|l|c|c|c|c|c|l|}
\hline Treatment & AADT $^{1}$ & Pavement Distress & Rutting (in) & $\begin{array}{c}\text { IRI } \\
\text { (in/mi) }\end{array}$ & $\begin{array}{c}\text { Friction } \\
\text { Treatment? }\end{array}$ & Surface Aging \\
\hline Crack seal & Any & $\begin{array}{c}\text { Low to moderately } \\
\text { severe surface cracks }\end{array}$ & $\mathrm{n} / \mathrm{a}$ & $\mathrm{n} / \mathrm{a}$ & No & $\mathrm{n} / \mathrm{a}$ \\
\hline Fog seal & $<5000^{2}$ & $\begin{array}{c}\text { Low severity } \\
\text { environmental cracks }\end{array}$ & $\mathrm{n} / \mathrm{a}$ & $\mathrm{n} / \mathrm{a}$ & No $^{3}$ & $\begin{array}{l}\text { Reduces aging and oxidation; } \\
\text { arrests minor raveling }\end{array}$ \\
\hline Seal coat & $<5000^{2}$ & $\begin{array}{c}\text { Low severity } \\
\text { environmental cracks }\end{array}$ & $<0.25^{4}$ & $\mathrm{n} / \mathrm{a}^{4}$ & Yes & $\begin{array}{l}\text { Reduces aging, oxidation and } \\
\text { minor raveling }\end{array}$ \\
\hline Microsurfacing & Any & $\begin{array}{c}\text { Low severity surface } \\
\text { cracks }\end{array}$ & Any & $<130$ & Yes & $\begin{array}{l}\text { Reduces aging, oxidation and } \\
\text { minor raveling }\end{array}$ \\
\hline $\begin{array}{l}\text { Ultra-bond } \\
\text { white coating }\end{array}$ & Any & $\begin{array}{c}\text { Low to moderately } \\
\text { severe surface cracks }\end{array}$ & $<0.25$ & $<140$ & Yes & $\begin{array}{l}\text { Reduces aging, oxidation and } \\
\text { moderate raveling }\end{array}$ \\
\hline HMA inlay & Any & $\begin{array}{c}\text { Low to moderately } \\
\text { severe surface cracks }\end{array}$ & Any & $<150$ & Yes & $\begin{array}{l}\text { Reduces aging, oxidation and } \\
\text { raveled surface }\end{array}$ \\
\hline HMA overlay & Any & $\begin{array}{c}\text { Low to moderately } \\
\text { severe surface cracks }\end{array}$ & Any & $<150$ & Yes & $\begin{array}{l}\text { Reduces aging, oxidation and } \\
\text { moderate raveling }\end{array}$ \\
\hline
\end{tabular}

Notes: 1. For mainline pavement; 2. Unless traffic can be adequately controlled; 3. Treatment may reduce skid numbers; 4.

Treatment does not address this.

Table 2.7: INDOT PCC Preventive Maintenance Treatment Guidelines (INDOT, 2009)

\begin{tabular}{|c|c|c|c|c|c|}
\hline Treatment & $\mathrm{AADT}^{1}$ & Pavement Distress & $\begin{array}{c}\text { IRI } \\
(\mathrm{in} / \mathrm{mi})\end{array}$ & $\begin{array}{c}\text { Friction } \\
\text { Treatment? }\end{array}$ & $\begin{array}{l}\text { Surface } \\
\text { Aging }\end{array}$ \\
\hline Crack seal & Any & Mid-panel cracks with aggregate interlock & $\mathrm{n} / \mathrm{a}$ & No & $\mathrm{n} / \mathrm{a}$ \\
\hline $\begin{array}{l}\text { Saw and seal } \\
\text { joints }\end{array}$ & Any & $\begin{array}{l}>10 \% \text { joints with missing sealant; otherwise } \\
\text { joints in good condition }\end{array}$ & $\mathrm{n} / \mathrm{a}$ & No & $\mathrm{n} / \mathrm{a}$ \\
\hline $\begin{array}{l}\text { Retrofit load } \\
\text { transfer }\end{array}$ & Any & $\begin{array}{l}\text { Low to medium severity mid-panel cracks; } \\
\text { pumping or faulting at joints }<0.25 \text { in. }\end{array}$ & $\mathrm{n} / \mathrm{a}$ & No & $\mathrm{n} / \mathrm{a}$ \\
\hline $\begin{array}{l}\text { Surface } \\
\text { profiling }\end{array}$ & Any & $\begin{array}{c}\text { Faulting }<0.25 \text { in.; poor ride; friction } \\
\text { problems }\end{array}$ & $\mathrm{n} / \mathrm{a}$ & No & $\mathrm{n} / \mathrm{a}$ \\
\hline $\begin{array}{l}\text { Partial depth } \\
\text { patch }\end{array}$ & Any & Localized surface deterioration & $\mathrm{n} / \mathrm{a}$ & Yes & $\mathrm{n} / \mathrm{a}$ \\
\hline $\begin{array}{l}\text { Full depth } \\
\text { patch }\end{array}$ & Any & Deteriorated joints; faulting $\geq 0.25$ in.; cracks & $\mathrm{n} / \mathrm{a}$ & No & $\mathrm{n} / \mathrm{a}$ \\
\hline Underseal & Any & Pumping; voids under pavement & $\mathrm{n} / \mathrm{a}$ & No & $\mathrm{n} / \mathrm{a}$ \\
\hline Slab jacking & Any & Settled slabs & $\mathrm{n} / \mathrm{a}$ & No & $\mathrm{n} / \mathrm{a}$ \\
\hline
\end{tabular}

Notes: 1. For mainline pavement.

\subsection{Evaluating Pavement Preservation Treatment Effectiveness}

Another element of a pavement preservation program is a proper mechanism for evaluating treatment effectiveness. Treatment effectiveness, or deterioration reduction, may be viewed as the increase in "positive" service attributes (or reduction in "negative" attributes) of an infrastructure system in response to treatment. In the context of highway pavements, such effectiveness may be in the form of an improved surface condition [such as present serviceability index (PSI), pavement condition rating (PCR), surface distress severity] or decreased surface roughness [international roughness index (IRI)]. Effectiveness can be classified into short- and long-term effectiveness. In the following sections, various performance measures that can be used to determine pavement preservation treatment effectiveness are discussed. 


\subsubsection{Short Term Pavement Treatment Effectiveness}

With regard to the number of monitoring periods used in the determination of short-term treatment effectiveness, there are many ways in which such effectiveness could be measured. The simplest is to use measurements taken at two points in time: one just before maintenance and another just after maintenance. The result of such computation would be an instantaneous performance jump due to maintenance. Another way is to use two measurements: one of which is taken at a specified time (say, 1 year) before maintenance and the other taken just after maintenance; or one in which measurement was taken at a time just before maintenance and the other taken a specified time after maintenance. Yet another way is to use three measurements: one taken a specified time (say, 1 year) before maintenance, the other taken at a time just before or just after maintenance, and the third measurement taken at a specified time well after maintenance. The third method enables the evaluation of maintenance effectiveness say, 1 year in terms of a reduction in the deterioration rate. An adjustment in pavement condition due to the application of maintenance may take one of two forms: (i) a modest improvement in current pavement condition (Lytton 1987; Markow 1991) measured instantaneously or after a finite time period and (ii) a reduction in the rate of deterioration subsequent to maintenance. It has also been indicated that both such phenomena can occur simultaneously (Mamlouk and Zaniewski 1998).

\subsubsection{Concept of Deterioration Reduction Level}

Deterioration reduction level (DRL) can be referred to as the delayed measurement of deterioration reduction or the subsequent reduction in deterioration. Labi and Sinha (2006) defines deterioration reduction level as the increase in infrastructure condition due to maintenance application, calculated on the basis of deterioration measurements taken between two consecutive, spaced-out points in time, typically 1 year.

Figure 2.5, which is a blown up section of a maintenance-induced kink in a performance curve, illustrates the DRL concept. Point A corresponds to the state or condition of the pavement at a specified time (say, 1 year) before maintenance, while point $\mathrm{D}$ is the state of the pavement just before maintenance is carried out. Point $\mathrm{F}$ is the state of the pavement just after maintenance, while point $\mathrm{E}$ is the state of the pavement a specified time after maintenance. Points $\mathrm{W}$ and $\mathrm{Z}$ are included for the sake of geometrical construction. $C_{i}$ and $t_{i}$ represent the condition of the pavement and the time of monitoring measurement, respectively, corresponding to any point $i$. The following lists three ways in which DRL has typically been (or could be) computed. 
1. Difference in deterioration between a specified time (say, 1 year) before maintenance (A) and just after maintenance $(\mathrm{F})$, as illustrated as $\Delta \mathrm{C}_{1}$ in the figure. This is DRL $\mathrm{TYPE}_{\mathrm{I}}$.

2. Difference in deterioration just before maintenance (D), and a specified time (say, 1 year) after maintenance (E), as illustrated as $\Delta \mathrm{C}_{2}$ in the figure. This is DRL $\mathrm{TYPE} \mathrm{II}_{\text {II }}$

3. Difference in deterioration a specified time (say, 1 year) before maintenance (A), and another specified time (say, 1 year) after maintenance (E), as illustrated as $\Delta \mathrm{C}_{3}$ in the figure. This is DRL $_{\text {TYPE III. }}$.

\section{Pavement \\ Condition}

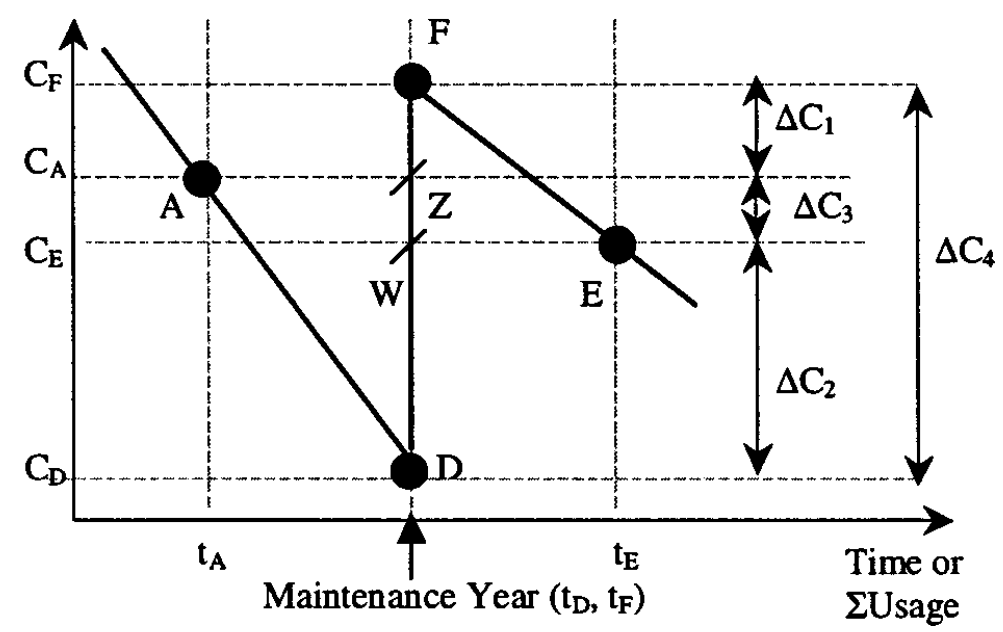

Figure 2.5: Deterioration reduction concept of measuring short-term effectiveness

All the above types of the DRL measure miss a vital component of maintenance effectiveness.

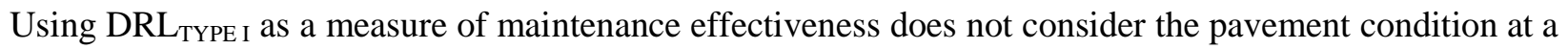
specific time just before maintenance, and therefore could not capture the effectiveness of maintenance in recovering pavement condition (from point $\mathrm{D}$ to point $\mathrm{Z}$ ). Therefore, the use of $\mathrm{DRL}_{\mathrm{TYPE}}$ underestimates maintenance effectiveness. Similarly, $\mathrm{DRL}_{\text {TYPE II }}$ does not consider the condition of the pavement just after maintenance, and the maintenance effectiveness in recovering pavement condition from point $\mathrm{W}$ to point $\mathrm{F}$ is missed. This means that using $\mathrm{DRL}_{\mathrm{TYPE}}$ II , similar to $\mathrm{DRL}_{\mathrm{TYPE}}$, could lead to underestimation of maintenance effectiveness. The argument against the use of the DRL concept is even clearer in the case of DRL $_{\text {TYPE III }}$ where the figure shows that, maintenance effectiveness is likely to be negative if this measure is used. This leads to the conclusion that maintenance is not effective which is not true. Each of these types of the DRL measure could be expressed in one of three ways: 
1. As an absolute change or a simple difference between two measurements in time relative to the first of the two measurements (such as a change in IRI, $\Delta$ IRI);

2. As a relative change or ratio of the change to the initial condition (e.g., $\Delta$ IRI/initial IRI);

3. As a percentage change relative to the initial condition [e.g., $100 \times(\Delta \mathrm{IRI} / \mathrm{initial} \mathrm{IRI})]$.

In past studies, DRL has been the most commonly used measure of short-term maintenance effectiveness. This measure was used in the determination of roughness change over a 1 year period in response to various types of routine maintenance treatments (Fwa and Sinha, 1987). Fwa and Sinha (1987) developed models that predict the change in PSI as a function of maintenance and pavement attributes. Also, a routine maintenance study in Indiana (Sinha et al., 1988) modeled maintenance effectiveness (expressed as the relative change in pavement roughness) as a function of climate and unit maintenance expenditure. In that study, the response variable for the maintenance effectiveness models was computed as follows:

$\mathrm{RRN}=\mathrm{RN}_{i}-\mathrm{RN}_{i+1} / \mathrm{RN}_{i}$

where $\mathrm{RRN}$ = reduction in roughness of a pavement section due to maintenance; and $\mathrm{RN}_{\mathrm{i}}=$ roughness of a pavement section in year $i$, in counts per mile. The conclusion of that study that "for most treatments, roughness increases after treatment, regardless of maintenance expenditure level" was probably due to the use of DRL as the measure of maintenance effectiveness.

\subsubsection{Concept of Performance Jump}

Performance jump (PJ) can be defined as the vertical or instantaneous elevation in the performance or condition of a pavement due to maintenance (see $\Delta \mathrm{C}_{4}$ in Figure 2.5). This is computed using values of deterioration taken just before and just after maintenance. The performance jump concept has often been the subject of discussion (Lytton, 1987), but has seen relatively little application. Colluci-Rios and Sinha (1985) used the concept of performance jump to develop equations that estimate the instantaneous reduction in roughness due to overlays of varying thicknesses. Rajagopal and George (1991) expressed performance jump as the difference in PCR just after treatment and PCR just before treatment, and then proceeded to model such effectiveness as a function of overlay thickness. Markow (1991) expressed maintenance effectiveness as $\Delta \mathrm{P}_{\mathrm{t}}$, the adjustment in pavement PCI due to routine maintenance in year $\mathrm{t}$, and used this measure as a dependent variable in an effectiveness model as a function of treatment and other attributes. Mouaket et al. (1992) measured the effectiveness of seal coating in terms of a jump in PSI, and then modeled such effectiveness as a function of initial pavement condition. 
By involving just-before maintenance and just-after maintenance values of deterioration, Labi and Sinha (2006) noted that the performance jump measure avoids the time-related pitfalls associated with the deterioration reduction level measure, and therefore offers what is probably the best means of assessing maintenance effectiveness in the short term. It is noted that the shorter the duration of a given maintenance activity and the smaller the time or usage interval between deterioration measurements and maintenance, the more accurate the value obtained for performance jump. However, because agencies typically do not carry out deterioration measurements just before and just after maintenance, it is often difficult to obtain data for $\mathrm{PJ}$ computation. Therefore, it is necessary to extrapolate the performance curve from both directions to the point of maintenance, to obtain PJ values. In cases where just-before and justafter-maintenance deterioration measurements were taken, the issue of relative timing between maintenance and monitoring (deterioration measurements) is inconsequential to the computation of performance jump. However, when deterioration is monitored over a minimum of relatively large time intervals such as 1 year, it is imperative to ascertain whether monitoring occurred before maintenance or vice versa, as such determination is critical to the selection of appropriate formula for performance jump.

Labi et al. (2007) utilized the performance jump concept to study the short-term effectiveness of micro-surfacing using indicators such as the IRI and the PCR. Microsurfacing offers a significant performance jump upon application as follows: $0.237-0.632 \mathrm{~m} / \mathrm{km}$ of IRI reduction (average 0.442 ); up to $5 \mathrm{~mm}$ of rut reduction (average 4); 3-9 units of PCR increase (average 6.2). The analysis determined that the short-term effectiveness of the treatment is largely influenced by the pavement condition just before treatment: Within the range of pretreatment conditions encountered, the lower the pretreatment condition, the higher the performance jump.

\subsubsection{Concept of Deterioration Reduction Rate}

The DRR concept involves the "slowing down" of pavement deterioration with respect to time or cumulative loading, due to the application of maintenance. Maintenance is perceived to change the steep slope associated with a rapidly deteriorating pavement to a gentle slope. DRR is calculated as the difference in the slope of the deterioration curve before maintenance and after maintenance. It is worth noting that the DRR concept is more readily appreciated by considering a long-term performance curve where all kinks due to performance jumps have been smoothed out to yield a continuous curvy line on which a gentle slope suddenly following a steep slope is indicative of the application of maintenance. Johnson and Cation (1992) concluded that the effect of maintenance was to produce a significant flattening or even reversal of direction (upward trend) of the deterioration curve, a finding which is consistent with the DRR concept. 


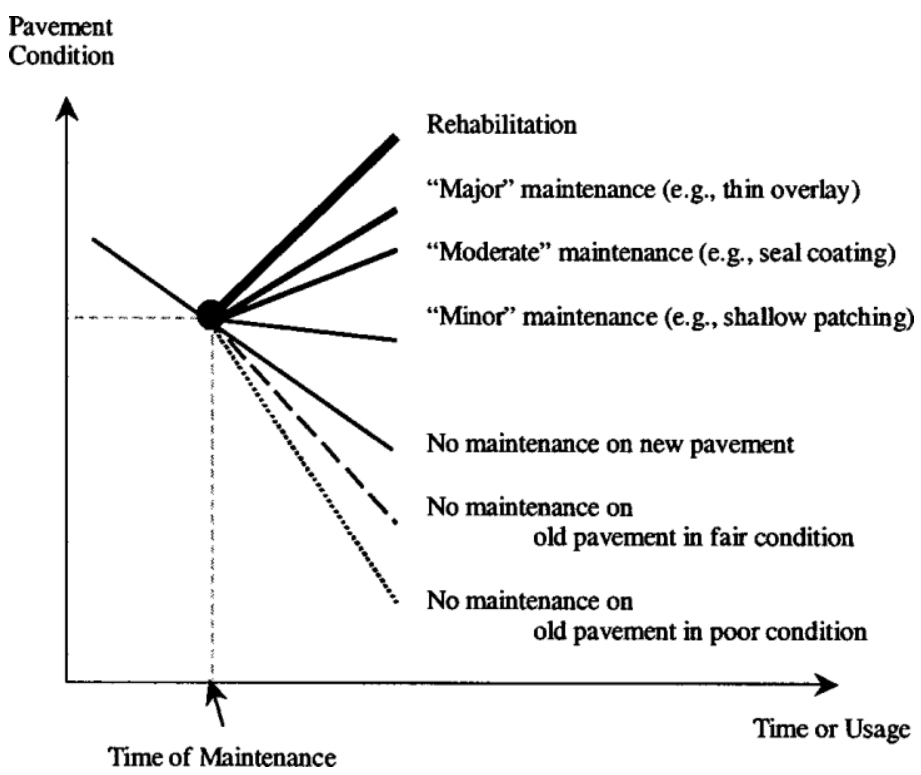

Figure 2.6: Conceptual illustration of deterioration reduction rate

Figure 2.6 provides a conceptual illustration of the reduction in the deterioration rate in response to a variety of pavement repair actions and pavement conditions. In the figure, pavement deterioration is assumed to be linear over that period, as maintenance effectiveness is being viewed over a relatively short period of time, compared to pavement life. As the figure suggests, old pavements in poor condition suffer relatively high rates of deterioration if denied maintenance, an observation that is well founded from past research. In contrast, new pavements in good condition are assumed to deteriorate at the same rate if left without maintenance. These assumptions are consistent with the classical shape of the typical pavement performance curve that shows slow and linear deterioration at the initial phases of pavement life, but accelerated rates of deterioration as the pavement advances in age. Subsequent to relatively "minor" maintenance such as crack sealing and shallow patching, pavements are nevertheless expected to exhibit deterioration over time, albeit at a reduced rate. As the level of pavement maintenance increases, the deterioration curve takes on increasingly positive gradients, as suggested in the figure.

Discussion on this measure of maintenance effectiveness has been largely conceptual (Lytton, 1987; Markow, 1991) and deterioration rate reduction due to a specific maintenance treatment (or specific combinations thereof) is best determined when the pavement received no other treatment in the time vicinity of the maintenance application, so that the occluding effect of such "extraneous" treatments is obviated. A minimum of three data points in time (corresponding to two monitoring periods), is recommended for DRR computation (Labi and Sinha, 2006). 


\subsubsection{Long Term Treatment Effectiveness}

Unlike short-term effectiveness which considers improvement in performance due to a particular treatment, evaluation of the long-term effectiveness of preservation is concerned with the performance of the particular improvement over the entire pavement life cycle. Typically various measures had been proposed and these include (i) pavement service life, (ii) remaining service life, (iii) increased average pavement condition over service life, or (iv) increased area under performance curve due to the intervention. These measures of long-term effectiveness can be determined in a disaggregate manner (using manual plots each for individual for pavement sections that received the treatment under investigation), or in an aggregate manner (using performance curves developed using data from multiple pavement segments that received the treatment).

A key to evaluate long-term effectiveness of interventions is to establish the performance model for the treatment over the period until such a time the pavement condition returns to its pre-treatment performance level. Performance models that have been developed in past research may be categorized as follows: (i) purely mechanistic models which are based on primary response parameter such as stress, strain or deflection; (ii) mechanistic-empirical models where the response parameter (stress, strain or deflection) is related to structural or functional deterioration (such as distresses) through analytical methods such as regression; (iii) empirical (often statistical) models where the dependent variable (structural or functional deterioration) is related to one or more independent variables such as strength of supporting elements (such as soils and foundation), loading, and environmental factors and their interactions; and (iv) subjective models where experience is "captured" in a formalized or structured way using transition process models to develop pavement prediction models (Haas et al., 1994).

Figure 2.7 shows the performance of a pavement subject to a treatment. In Figure 2.7(a), the figure is shown for the so-called "positive" or decreasing measures of performance, such as Pavement Condition Rating (PCR), Present Serviceability Index (PSI) etc., whose increasing values indicate better performance. In Figure 2.7(b), the figure shows typical trends of so-called "negative" or increasing measures of performance such as surface roughness, faulting index, rut index whose increasing values indicate worsening performance.

If we define $\mathrm{f}_{\mathrm{b}}(\mathrm{t})$ = performance curve before treatment; $\mathrm{f}_{\mathrm{a}}(\mathrm{t})=$ performance curve after treatment, $\mathrm{y}=$ pavement performance measure; $\mathrm{y}_{\mathrm{t}}=$ allowable threshold level; $\mathrm{t}_{1}=$ time when treatment is performed; $\mathrm{t}_{2}=$ expected time when pavement reaches threshold level; $\mathrm{t}_{3}=$ expected time when the treated pavement reaches threshold level, the following long term performance measures can be obtained:

Service life after treatment $\mathrm{SL}_{\mathrm{a}}=\mathrm{t}_{3}-\mathrm{t}_{1}$

Service life extension due to treatment $\mathrm{SLE}=\mathrm{t}_{3}-\mathrm{t}_{2}$ 


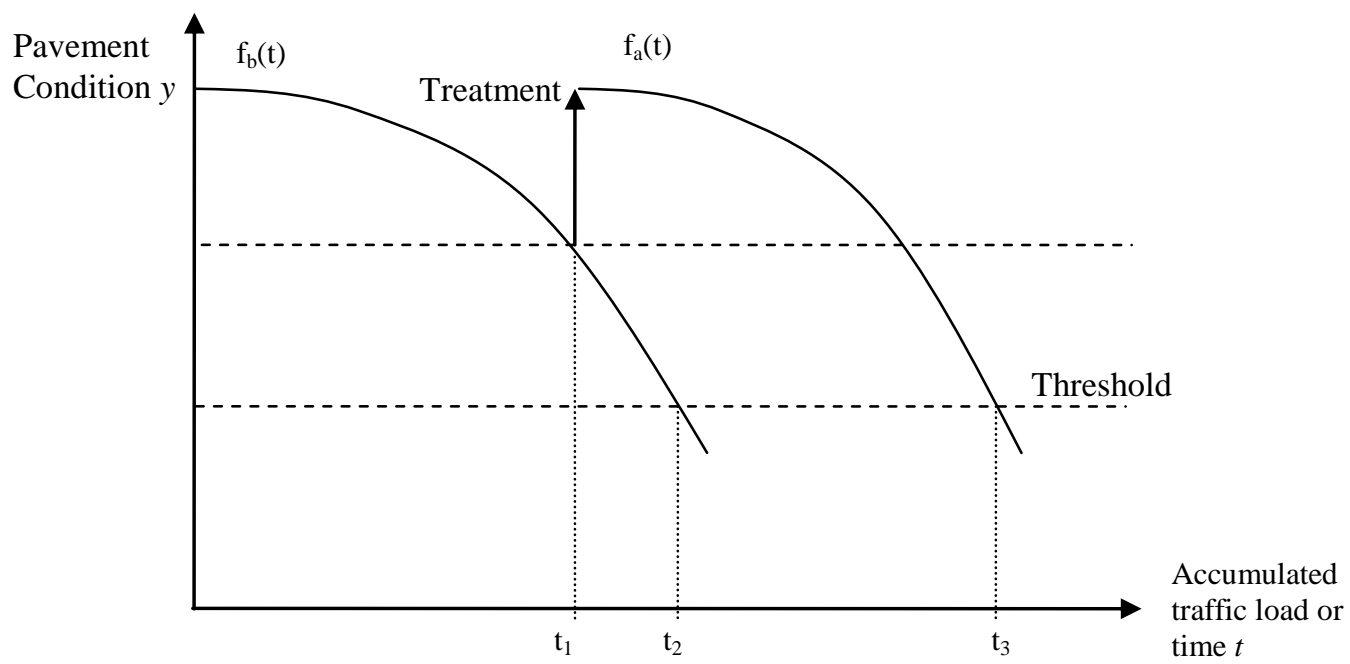

(a) Increasing performance attribute

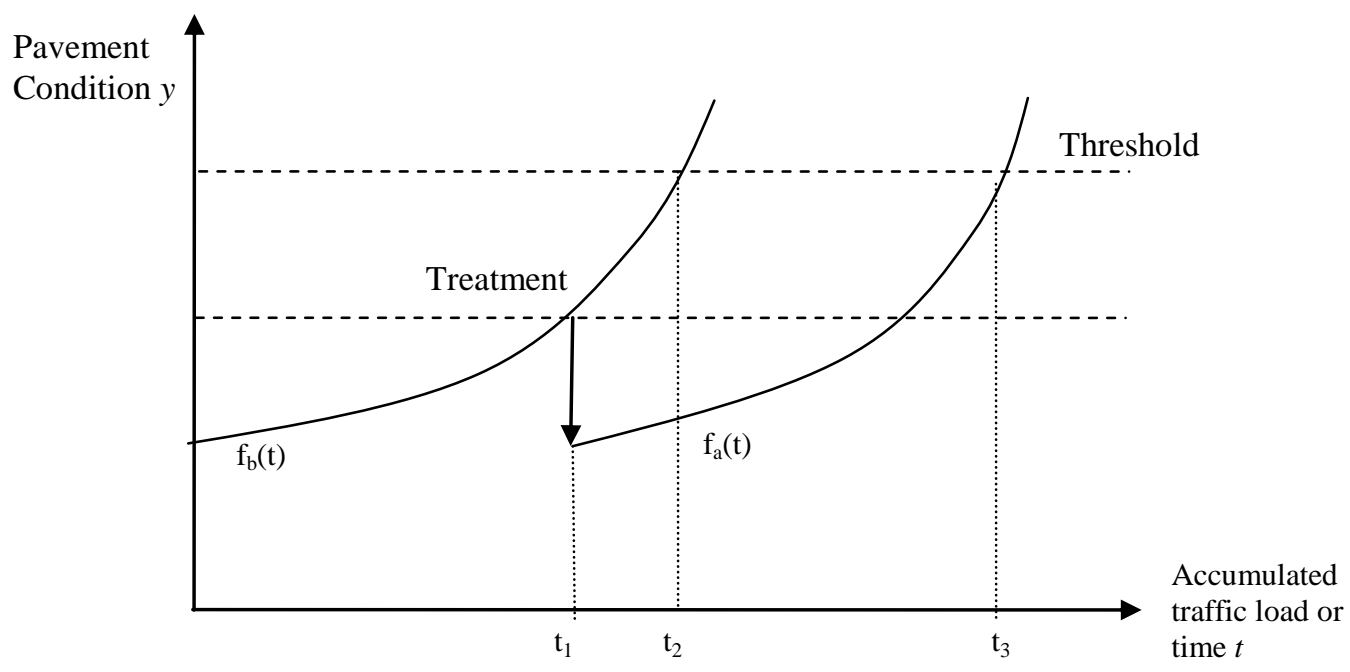

(b) Decreasing performance attribute

Figure 2.7: Illustration of pavement performance

Remaining service life of pavement before treatment $\mathrm{RSL}_{\mathrm{b}}=\mathrm{t}_{2}-\mathrm{t}_{1}$

Remaining service life of pavement after treatment $\mathrm{RSL}_{\mathrm{a}}=\mathrm{t}_{3}-\mathrm{t}_{1}$

Remaining service life extension RSLE $=\mathrm{RSL}_{\mathrm{a}}-\mathrm{RSL}_{\mathrm{b}}=\mathrm{t}_{3}-\mathrm{t}_{2}$

Average pavement condition over remaining service life without treatment $\mathrm{y}_{\mathrm{wo}}$

$=\frac{1}{t_{2}-t_{1}} \int_{t_{1}}^{t_{2}} f_{b} t d t$ 
Average pavement condition over service life after treatment $\mathrm{y}_{\mathrm{w}}=\frac{1}{t_{3}-t_{2}} \int_{t_{2}}^{t_{3}} f_{a} t d t$

Average increase in pavement condition over service life due to treatment $=\mathrm{y}_{\mathrm{w}}-\mathrm{y}_{\mathrm{wo}}$

Area under performance curve without treatment $\mathrm{Area}_{\mathrm{wo}}=\int_{t_{1}}^{t_{2}} f_{b} t-y_{t} d t$

Area under performance curve with treatment $\mathrm{Area}_{\mathrm{w}}=\int_{t_{2}}^{t_{3}} f_{a} t-y_{t} d t$

Increase in area under performance curve $=\operatorname{Area}_{\mathrm{w}}-\mathrm{Area}_{\mathrm{wo}}$

The area bounded by the performance curve and the threshold line (Eq. 2.10 and 2.11), embodies both concepts of average pavement condition and service life is probably one of the most commonly used performance measures in modern pavement management systems (Peterson, 1985; Labi and Sinha, 2003; Lamptey et al., 2004). For non-increasing performance indicators such as pavement condition ratings, this effectiveness is the area under the curve; while for non-decreasing indicators such as international roughness index (IRI) and rutting, this is the area over the curve (Figure 2.7). The rationale for this approach is simple. First, a well-maintained pavement (thus gently sloping performance curve, and subsequently, larger area bounded by the curve) provides the user with benefits that are greater than a poorly maintained pavement (steep performance curve having a small bounded area). Second, because the benefits of a well-maintained pavement are numerous and may be difficult to quantify in monetary terms, The area under the curve could also be used as a surrogate for overall user benefits that generally include reduced accidents, travel time, vehicle operating and maintenance costs, and others (Geoffrey, 1996; Lamptey et al., 2004).

In recent years, some pavement preservation researchers have advocated the use of remaining service life (Eq. 2.4 and 2.5) as a key performance measures for long-term effectiveness. The rationale is simple: remaining service life is the actual useful asset life of the asset before the condition reaches it service threshold. This term is simple to measure and easy to understand to engineers, administrators, legislature and the general public. Coupling with the fact that current infrastructure funding is limited, it was proposed by O'Doherty (2007) as part of the overall pavement preservation concept to use remaining service life (and extension) as a measure to quantify network performance. This concept has been applied in various studies. For example, Shiyab et al. (2006) developed flexible pavement remaining life models for the use in the PMS. Particularly, the authors found that effective Structural Number $\left(\mathrm{SN}_{\mathrm{eff}}\right)$, IRI and PQI yearly loss are suitable parameters to predict pavement remaining lives. Chou et al. (2008) developed regression and Markov probabilistic models to forecast future pavement conditions and to determine remaining service life of pavements managed by the Ohio Department of Transportation (ODOT). Yang 
(2009) developed duration-based remaining service life models for the Florida Department of Transportation pavement management system. Pavement condition rating is used in his formulation as a surrogate variable to account for pavement structural data which is absent in FDOT's PMS databases. Irfan et al. (2009) made use of measures such as performance jump (short-term), and service life and increase in pavement performance (long-term) to evaluate the effectiveness of asphalt rehabilitation treatments in Indiana. Berg et al. (2009) made use of treatment service life to explore the use of Type III microsurfacing on concrete pavements on I-70 in Richfield district, Utah.

\subsection{Programming of Pavement Preservation and Rehabilitation Treatments}

An effective annual or single year preservation and rehabilitation work program should contain prioritized lists of roads for executive managers. The objective can be as simple as "by decreasing total present worth of preservation and rehabilitation cost" or as complicated as "nonlinear mathematical optimization." In most cases, agency and user costs, pavement serviceability and condition index, functional classification, and traffic level are considered and the total preservation and rehabilitation costs should not exceed the pre-selected budget levels.

When determining an effective pavement preservation and rehabilitation program, priority ranking and optimization procedures are commonly used. These techniques aid in evaluating inter-project tradeoffs in selecting maintenance and rehabilitation strategies, and selecting strategies that adhere to constraints in budget. The priority ranking approach in selecting projects is usually simple, but the solutions provided are usually far from optimal. Mathematical optimization, on the other hand, is more complex than prioritization approaches, but tends to be more effective in setting up strategies that meet agency goals. Table 2.8 summarizes the different techniques that can be used to determine the optimal project selection strategy.

The application of optimization routines in pavement management systems has become fairly common today. Most mathematical optimization methodologies require current condition data on all pavement sections at the network level, treatment alternatives and their associated costs, and improvement in pavement condition from each alternative. The optimization procedure defines an objective function and aims to minimize the overall cost or maximize the benefit-cost ratio subject to certain constraints, and find cost-effective solutions. The methodologies seek to choose the best set of candidate sections based on their current performance. After the first year budget is exhausted then simply predict the future condition in the next year, select the best set of the remaining projects, and so on. However, this type of optimization may not provide the true optimal solution because it does not consider the best M,R\&R timing for the candidate sections. A "true" optimization should also address the 
dimension of timing and selects the best sequence of M,R\&R strategies over several years (FHWA, 1990). The "true" optimization is computationally complex depending on the number of pavement sections and size of the network, number of condition states, and constraints. The mathematical optimization (or near optimization) functions are used to generate PMS work programs and budgets consistent with their performance goals and financial constraints. The mathematical optimization problems can be solved for true and exact optimal solutions by several approaches: linear and nonlinear programming, integer programming, and dynamic programming (FHWA, 1990; Zimmerman, 1995).

Table 2.8: Comparison of prioritization methods (Haas et al., 1994)

\begin{tabular}{|c|l|l|}
\hline 1 & Class of Method & Advantages and Disadvantages \\
\hline 1 & $\begin{array}{l}\text { Simple subjective ranking of projects based on judgment, } \\
\text { overall condition index or decreasing first year cost (single } \\
\text { year or multi-year) }\end{array}$ & $\begin{array}{l}\text { Quick, simple; subject to bias and inconsistency; } \\
\text { may be far from optimal }\end{array}$ \\
\hline 2 & $\begin{array}{l}\text { Ranking based on condition parameters, such as } \\
\text { serviceability or distress; can be weighted by traffic (single } \\
\text { or multi-year) }\end{array}$ & $\begin{array}{l}\text { Simple, easy to use; may be far from optimal, } \\
\text { particularly if traffic weighting is not used }\end{array}$ \\
\hline 3 & $\begin{array}{l}\text { Ranking based on condition parameters and traffic, with } \\
\text { economic analysis including decreasing present worth cost } \\
\text { or benefit cost ratio (single or multi-year) }\end{array}$ & $\begin{array}{l}\text { Reasonably simple, may be closer to optimal } \\
\text { for year-by-year basis over analysis period }\end{array}$ \\
\hline 5 & $\begin{array}{l}\text { Near-optimization using heuristics approaches including } \\
\text { incremental benefit-cost ratio and marginal cost- } \\
\text { effectiveness (M,R\&R timing taken into account) }\end{array}$ & $\begin{array}{l}\text { Reasonably simple; suitable for microcomputer } \\
\text { timing not considered }\end{array}$ \\
\hline 6 & $\begin{array}{l}\text { Comprehensive optimization by mathematical programming } \\
\text { models taking into account the effects of M,R\&R timing }\end{array}$ & $\begin{array}{l}\text { Most complex and computationally demanding; } \\
\text { can give optimal program (maximization of } \\
\text { benefits or cost-effectiveness) }\end{array}$ \\
\hline
\end{tabular}

Colucci-Rios et al. (1984) developed a multi-year optimization model (the contract section worth model) which uses the weighed reduction in pavement distress over a five year period as the measure of effectiveness. This method allows the determination of the optimal resurfacing priorities in the pavement management system in Indiana. Fwa et al. (1988) uses integer programming to perform the priority assessment of routine maintenance needs and the optimal programming of routine maintenance activities. Abaza and Ashur (1999) developed a pavement management model using a microscopic approach to yield optimum pavement conditions for a given pavement system. The microscopic pavement management problem is formulated as a constrained integer linear programming model subjected to budget and improvement requirement constraints. Integer variables representing the number of pavement sections to be treated by the applicable maintenance and rehabilitation actions were incorporated in the model. The objective of yielding optimum pavement conditions is achieved by either considering the net pavement condition rating gain or age - gain applied to a given pavement system. It was shown that the model can yield optimum pavement conditions. Other approaches, such as dynamic programming or 
artificial intelligence, have also been adopted by many researchers in the recent years to integrate maintenance or preservation considerations in the pavement management systems (Zheng et al., 2009; Gao and Zhang., 2009).

\subsection{Need for Pavement Preservation Framework in Indiana}

In recent years, there has been an emerging interest in infrastructure preservation at the national at state levels. For example, California Department of Transportation (Caltrans) formed a Pavement Preservation Task Group (PPTG) aimed at promoting pavement preservation. Comprised of representatives from the Caltrans, the local government, industry and the Federal Highway Administration (FHWA), the group has been proactive in promoting pavement preservation initiatives. One of such initiatives include the development of the Caltrans Maintenance Technical Advisory Guide (MTAG) which is a comprehensive reference guide on pavement preservation strategies, including materials and applications requirements, field guidance and troubleshooting, and strategy selection (Caltrans, 2002). Georgia Department of Transportation's (GDOT) has also started an asphalt pavement preservation program aimed at applying low-cost treatments to retard a highway's deterioration, maintain the functional condition, and extend the pavement's service life cost.

The Indiana Department of Transportation (INDOT) has recognized the importance of pavement preservation. Although past works (Cullocis-Rio et al., 1984; Fwa and Sinha, 1985; Feighan et al., 1986; Fwa et al., 1988; Sinha et al., 1988; Mouaket et al., 1990; Lamptey et al., 2004, Sinha et al., 2005) allowed the understanding of the issues involved in maintenance and rehabilitation operations and the effects of these on pavement performance, there is still a gap between the integration of pavement preservation and pavement management, especially at the implementation level. This study therefore aims to develop a pavement preservation program framework for INDOT and integrates the various components of pavement preservation at a district and network level. An integration of pavement preservation and pavement management will not only streamline operations within the agency, but can also bring in tremendous benefits in terms of the remaining service life of our highway assets. This is critical especially in the current economic climate and the need to maintain our infrastructural conditions to meet user expectations. 


\title{
CHAPTER 3: STUDY METHODOLOGY
}

\author{
$\underline{3.1 \quad \text { Introduction }}$
}

Recognizing the imperative need for a cost-effective solution to maintain the pavement infrastructures, this study aims to develop a pavement preservation framework for the state of Indiana. This framework allows network level consideration of pavement preservation within the existing pavement management system and also allows district engineers to incorporate elements of pavement preservation in their decision making process. This chapter presents the overall study framework adopted in this report. The study only focuses on pavement preservation treatments and does not consider the effect of rehabilitation and reconstruction activities.

\section{$\underline{3.2 \quad \text { Study Framework }}$}

Figure 3.1 shows the overall research framework in this study and how each chapter relates to the development of the INDOT pavement preservation framework.

\subsection{Study Methodology}

\subsubsection{Integrating Pavement Preservation Concepts within a Pavement Management System}

The study first attempts to provide means to integrate pavement preservation considerations within the network-level pavement management system. In particular, two main aspects are important in integrating pavement preservation within a PMS structure. This include: (i) determining triggers for pavement preservation treatments for use in a PMS, and (ii) development of performance models for preservation treatments so that they can be considered in a PMS framework.

The first part of the study effort calls for the development of thresholds or decision matrices that allow the "triggering" of preservation and rehabilitation treatments. This enables the highway agency to consider preservation treatments in their planning and budgeting process, and hence promote a more long 
term (and sustainable) view of pavement preservation. The second part of the study effort is targeted to develop pavement performance models (both long term pavement performance and short term performance jumps) that can be directly inputted into the existing pavement management systems used by highway agencies. Costs for preservation treatments shall also be identified. A remaining service life approach for pavement preservation strategy selection shall also be developed. These two efforts will allow an over-arching consideration of preservation (and remaining service life) concept in pavement management.

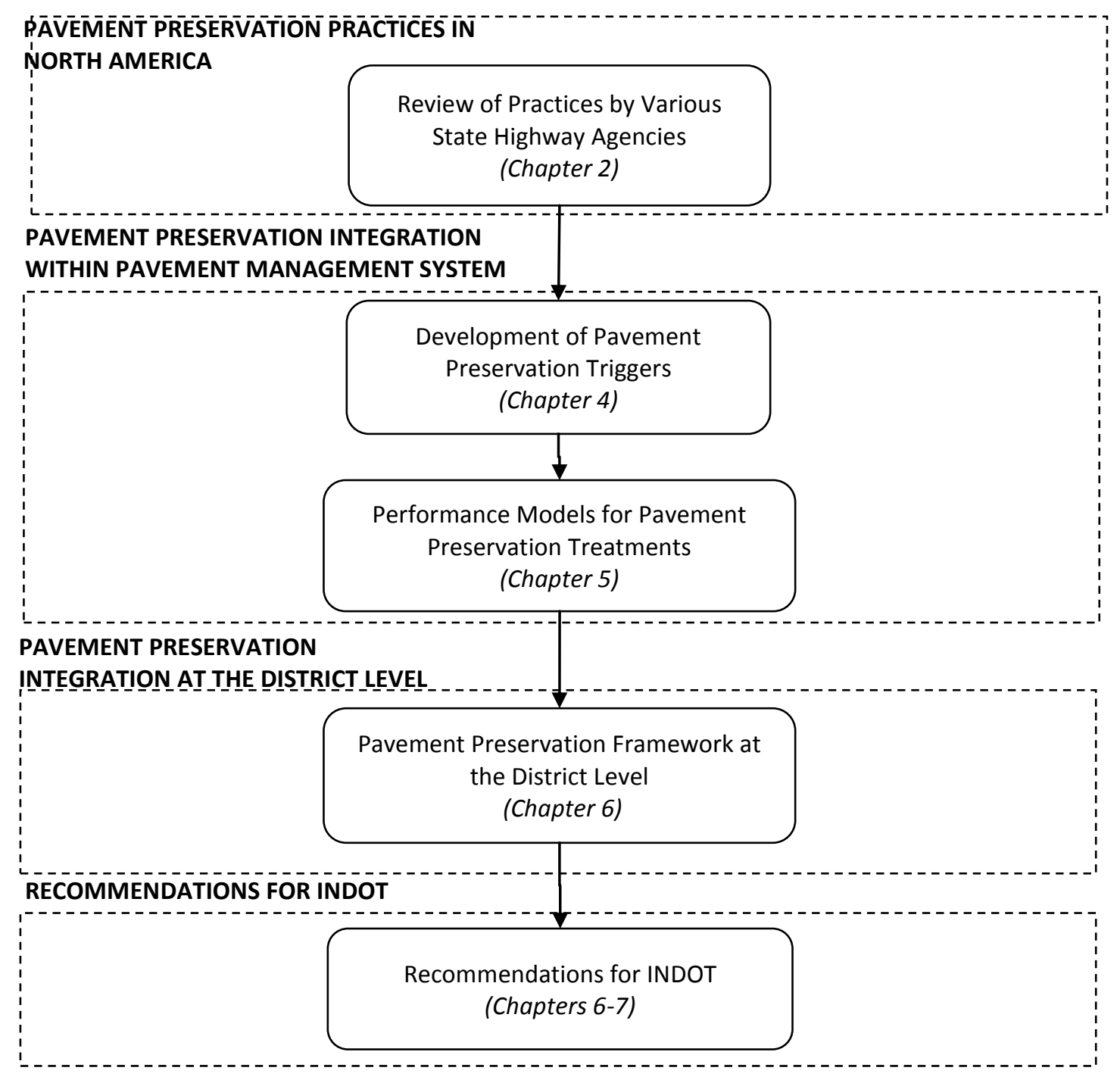

Figure 3.1: Overview of study framework 


\subsubsection{Pavement Preservation at the District Level}

It is insufficient to integrate pavement preservation concepts within the pavement management system at the network level (or at the central office level). Pavement preservation concept has to be implemented at all levels of the state highway agencies (i.e. central office, districts and district-subs). In this study, attention is paid on developing a framework that integrates the central office of a state highway agency to the districts. The benefits of considering pavement preservation at the network and district level shall also be demonstrated. In particular, the remaining service life approach is adopted in this study to determine the type of preservation treatment to be performed on a given network. 


\title{
CHAPTER 4: DEVELOPMENT OF THRESHOLD LEVELS FOR PAVEMENT PRESERVATION TREATMENTS
}

\author{
$\underline{4.1 \quad \text { Introduction }}$
}

An important component of a pavement preservation program is the development of appropriate threshold levels or triggers for pavement preservation treatments. In most practical network level pavement management systems, surface condition and pavement roughness data is commonly used to develop pavement treatment intervention levels. Typical procedures used to select appropriate treatments include (Uddin, 2006):

- "ad-hoc" based on past experience, subjective judgment, or personal preference,

- based upon distress type and severity, such as the PAVER procedure (Shahin and Walther, 1990),

- use of a composite index; for example, PCR as a function of distress attributes and IRI,

- calculation of the life-cycle costs and benefits considering roughness and distress attributes for interventional levels and selection of the most economical one,

- a decision tree approach considering all distress type and other condition attributes, and

- application of modern artificial intelligence technologies (expert system, fuzzy set, ANN).

Many limitations can be identified with some of the above procedures. The traditional ad hoc policy was the norm before PMS concepts were developed. The use of one or more composite index in some current PMS programs is oversimplification; it misses the mechanism leading to condition deterioration and, therefore, results in an inappropriate maintenance treatment. The use of life cycle costs and benefits may be useful in providing cost-effective solutions, but a great deal of time and effort is required to quantify performance and life cycle behavior of preservation treatments. Moreover, the procedure still requires some form of intervention levels or triggers when selecting treatments in the network level pavement management system. To date, the decision tree approach is the most popular, but it can be very complex when more condition attributes are considered.

In this chapter, two different procedures are developed to determine intervention levels for pavement preservation and rehabilitation activities. They are:

- Historical intervention levels at which preservation treatments were applied, and 
- Expert opinions based decision matrices to determine the timing when preservation treatment should be performed.

These two procedures use information that can be easily collected and implemented by any state highway agency. Also, the following pavement performance measures are used to develop relevant intervention levels for pavement maintenance and preservation treatment:

- Pavement roughness (in terms of international roughness index IRI)

- Crack type and severity (load and non-load associated)

- Rut on asphalt pavements (in terms of rut depth)

- Fault on jointed (or jointed-reinforced) concrete pavements (in terms of fault depth)

- Friction level (in terms of skid number)

- Functional classification of highway, as a surrogate of design and traffic loading

Table 4.1 summarizes the performance measures and their definitions while Table 4.2 illustrates the different treatments considered in the paper.

\subsection{Determining Pavement Threshold Levels using Historical Data}

Historical practices on when preservation and maintenance treatments are performed provide a ready source of information for highway agencies to develop pavement intervention levels. While the use of composite ratings has been the predominant approach adopted by past researchers to determine pavement intervention levels at the network level, it cannot offer a distress-based perspective required to activate preservation treatments in a network-level PMS (Haas et al., 1994; Bekheet et al., 2005). With the availability of individual distress condition data, it is possible to re-look into development of pavement preservation intervention levels using surface distress data, along with other conventional measures of pavement conditions (e.g. roughness, ruts, faults and friction). In this section, a demonstration on how state highway agencies can develop their own pavement preservation intervention levels is illustrated. As an illustration, data from the state of Indiana is used in the paper.

\subsubsection{Data Collection}

Historical pavement work information on the Indiana state highway system and their associated pavement conditions were collected over a period of 11 years (from 1998 to 2008). The relevant information includes:

- Work contract data, which is available from the pavement management system 
Table 4.1: Pavement Attributes Considered in Study

\begin{tabular}{|c|c|c|}
\hline Category & Value or Rating & Definition \\
\hline \multirow[t]{2}{*}{ Pavement Type } & Asphalt & Asphalt pavement. \\
\hline & Concrete & Jointed or jointed-reinforced concrete pavement. \\
\hline \multirow[t]{5}{*}{ International Roughness Index } & Continuous value & Measure of pavement roughness. \\
\hline & \multicolumn{2}{|l|}{ Discrete Rating } \\
\hline & Excellent & $\begin{array}{l}\text { Asphalt pavement: IRI }<80 \text { inch/mile. } \\
\text { Jointed or jointed-reinforced concrete pavement: IRI }<115 \text { inch/mile. }\end{array}$ \\
\hline & Fair & $\begin{array}{l}\text { Asphalt pavement: } 80 \text { inch/mile }<\text { IRI }<150 \text { inch } / \text { mile. } \\
\text { Jointed or jointed-reinforced concrete pavement: } 115 \text { inch/mile }<\text { IRI }< \\
150 \text { inch/mile. }\end{array}$ \\
\hline & Poor & $\begin{array}{l}\text { Asphalt and jointed or jointed-reinforced concrete pavements: IRI > } 150 \\
\text { inch/mile. }\end{array}$ \\
\hline \multirow{4}{*}{$\begin{array}{l}\text { Load-Associated Cracks (e.g. } \\
\text { wheel path longitudinal cracks } \\
\text { and alligator cracks for asphalt } \\
\text { pavements; single and multiple } \\
\text { cracks in jointed or jointed- } \\
\text { reinforced concrete pavements) }\end{array}$} & No distress & No distress. \\
\hline & Low severity & $\begin{array}{l}\text { Asphalt pavement } \\
\text { Longitudinal crack: Crack width less than } 0.25 \text { in. or sealed cracks with } \\
\text { sealant material in good condition and the width cannot be determined. } \\
\text { Alligator cracks: An area of cracks with no or only a few connecting } \\
\text { cracks; cracks are not spalled or sealed; pumping is not evident. } \\
\text { Jointed (or jointed reinforced) concrete pavement } \\
\text { Single crack: Crack widths }<0.125 \text { in or width too fine to be determined. }\end{array}$ \\
\hline & Moderate severity & $\begin{array}{l}\text { Asphalt pavement } \\
\text { Longitudinal crack: Crack width between } 0.25 \text { and } 0.75 \text { in. } \\
\text { Alligator cracks: An area of interconnected cracks forming a complete } \\
\text { pattern; cracks may be slightly spalled; cracks may be sealed; pumping is } \\
\text { not evident. } \\
\text { Jointed (or jointed reinforced) concrete pavement } \\
\text { Single crack: Crack widths between } 0.125 \text { in. and } 0.5 \mathrm{in} \text {. }\end{array}$ \\
\hline & High severity & $\begin{array}{l}\text { Asphalt pavement } \\
\text { Longitudinal crack: Crack width more than } 0.75 \text { in. } \\
\text { Alligator cracks: An area of moderately or severely spalled } \\
\text { interconnected cracks forming a complete pattern; pieces may move } \\
\text { when subjected to traffic; cracks may be sealed; or pumping is evident. } \\
\text { Jointed (or jointed reinforced) concrete pavement } \\
\text { Single crack: Crack width more than } 0.5 \mathrm{in.}\end{array}$ \\
\hline \multirow{4}{*}{$\begin{array}{l}\text { Non-Load-Associated Cracks } \\
\text { (e.g. transverse cracks and non- } \\
\text { wheel path longitudinal cracks } \\
\text { for asphalt pavements) }\end{array}$} & No distress & Same definition as above. \\
\hline & Low severity & Same definition as above. \\
\hline & Moderate severity & Same definition as above. \\
\hline & High severity & Same definition as above. \\
\hline \multirow[t]{6}{*}{ Rutting (for asphalt pavements) } & Continuous value & $\begin{array}{l}\text { Measure of transverse deformation along wheel path for asphalt } \\
\text { pavements. }\end{array}$ \\
\hline & Discrete Rating & \\
\hline & No distress & No rutting. \\
\hline & Low severity & 0 in. $<$ Rut depth $<0.0625$ in. \\
\hline & Moderate severity & 0.0625 in. $\leq$ Rut depth $<0.25$ in. \\
\hline & High severity & Rut depth $\geq 0.25$ in. \\
\hline \multirow{6}{*}{$\begin{array}{l}\text { Faulting (for jointed or jointed- } \\
\text { reinforced concrete pavements) }\end{array}$} & Continuous value & Measure of differential levels between adjacent slabs. \\
\hline & Discrete Rating & \\
\hline & No distress & No faulting. \\
\hline & Low severity & 0 in. $<$ Fault depth $<0.1$ in. \\
\hline & Moderate severity & 0.1 in. $\leq$ Fault depth $<0.25$ in. \\
\hline & High severity & Fault depth $\geq 0.25$ in. \\
\hline \multirow[t]{2}{*}{ Friction Number $\left(\mathrm{SN}_{40}\right)$} & Good & Skid number at $40 \mathrm{mph}$ using smooth tire $\geq 20$ \\
\hline & Poor & Skid number at $40 \mathrm{mph}$ using smooth tire $<20$ \\
\hline \multirow[t]{2}{*}{ Functional Classification } & Interstate & Interstate highway pavement. \\
\hline & Non-Interstate & Non-interstate highway pavement. \\
\hline
\end{tabular}


Table 4.2: Pavement Preservation and Rehabilitation Treatments Considered in Study

(a) Asphalt Pavement

\begin{tabular}{|l|c|}
\hline Treatment & Treatment Category \\
\hline Do nothing & None \\
\hline Crack Seal & Maintenance \& Preservation \\
\hline Surface Treatment & Maintenance \& Preservation \\
\hline Microsurfacing & Maintenance \& Preservation \\
\hline Chip Seal & Maintenance \& Preservation \\
\hline Thin Preventive Maintenance Overlay & Maintenance \& Preservation \\
\hline Functional Overlay & Rehabilitation \\
\hline Hot Mix Asphalt Structural Overlay & Rehabilitation \\
\hline Asphalt Pavement Replacement & Reconstruction \\
\hline
\end{tabular}

(b) Concrete Pavement (Jointed or Jointed Reinforced)

\begin{tabular}{|l|c|}
\hline Treatment & Treatment Category \\
\hline Do nothing & None \\
\hline Crack Sealing & Maintenance \& Preservation \\
\hline Joint-Bump Repair and Load-Transfer Retrofitting & Maintenance \& Preservation \\
\hline Diamond Grinding and Grooving & Maintenance \& Preservation \\
\hline Partial Depth Repair (Concrete Pavement Restoration) & Maintenance \& Preservation \\
\hline Full Depth Repair (Concrete Pavement Restoration) & Maintenance \& Preservation \\
\hline $\begin{array}{l}\text { Hot Mix Asphalt or Portland Cement Concrete Structural } \\
\text { Overlay }\end{array}$ & Rehabilitation \\
\hline $\begin{array}{l}\text { Crack and Seat Portland Cement Concrete Slab, and HMA } \\
\text { Overlay }\end{array}$ & Rehabilitation \\
\hline Reconstruct Portland Cement Concrete Pavement & Reconstruction \\
\hline
\end{tabular}

- Past maintenance records, which is available from the work and maintenance management systems

- Network-level pavement condition data, available from the pavement management system

- Inventory data for relevant highway sections

The contract database in the PMS contains information on contract maintenance, rehabilitation and reconstruction projects within the state while the maintenance database details the information on routine maintenance activities performed by the sub-districts within the state. The PMS also contains relevant inventory data and location references that are necessary to link the different databases.

Network level condition data collected in the PMS is shown in Table 4.1. The data is primarily collected by the state using automated pavement condition data collection technologies. The entire network is surveyed for pavement surface distresses and pavement roughness annually by a private vendor using the automated data collection procedure (INDOT, 1997). Distress identification is consistent with guidelines laid out in the INDOT distress identification manual (INDOT, 2002; Miller and Bellinger, 2003). Table 4.2 summarizes the treatments considered for the development of historical intervention 
levels. Treatments are classified into four categories: "do nothing", "maintenance and preservation", "rehabilitation" and "reconstruction". For this section, data on microsurfacing and chip-sealing performed in the state over the study period were few and were omitted in the study.

\subsubsection{Approach to Determine Intervention Levels from Historical Decisions}

Given the historical information as described earlier, a methodology to evaluate the intervention levels for pavement preservation and rehabilitation activities or treatments is described. Let $X_{i}=x_{i} \quad$ where $i=1$,

$2 \ldots I$, be the set of disaggregate pavement attributes and $Y_{j}=y_{j}$ where $j=1,2 \ldots J$, be the set of pavement decisions (which can be individual pavement treatment or treatment category). For a given historical decision $y_{j k}$, there is always a set of historical pavement conditions $X_{i j}=x_{i j}$ corresponding to this decision. In this case, the set of mean historical pavement conditions $\overline{X_{i j}}=\overline{x_{i j}}$ when a treatment is performed can be determined:

$\overline{x_{i j}}=\frac{1}{M} \sum_{m=1}^{M} x_{i j m}$

where $M$ is the total number of historical pavement decisions made. The standard deviation of the mean conditions at which a treatment is performed, $\sigma_{x_{i j}^{*}}$ can be determined using Eq. (4.2).

$\sigma_{x_{i j}}=\sqrt{\frac{1}{M} \sum_{m=1}^{M} x_{i j m}-\overline{x_{i j m}}}$

The desired intervention levels $X_{i j}^{*}=x_{i j}^{*} \quad$ can be evaluated using Eq. (4.3). $x_{i j}^{*}=\overline{x_{i j}}$

In the paper, it is assumed that the treatment intervention level is the mean historical conditions at which a treatment is performed.

\subsubsection{Pavement Thresholds from Historical Data}

Using data on past treatment decisions and their associated pavement conditions, historical intervention levels can be evaluated using Eq. (4.1) and (4.2) for the treatment categories defined in Table 4.2 and desired intervention levels for use in a network-level PMS are developed. The results of the analyses are described thereafter. 
Table 4.3 presents the mean conditions where past preservation, rehabilitation and reconstruction treatments are performed. Pavement sections where treatments were performed are randomly selected from the work contract and maintenance databases. It is observed that:

(a) Historical intervention levels in terms of IRI, PCR, crack, rut and fault severities are the highest for "reconstruction" action, followed by "rehabilitation" and lastly "maintenance and preservation". Similar observations are made for both asphalt and jointed (or jointed-reinforced) concrete pavements. This is consistent with the understanding that maintenance and preservation treatments are performed when pavements do not have severe structural deficiencies, unlike rehabilitation. Reconstruction, on the other hand, is performed when the pavement is near failure (as denoted as by the high IRI of more than $150 \mathrm{inch} / \mathrm{mile}$ and the presence of high-severity load-associated cracks).

(b) Mean historical intervention levels are more stringent (lower IRI, higher PCR, lower rut/fault depth, or lower distress severity) for interstate pavements, compared to non-interstate pavements. Interstate pavements tend to carry heavier traffic loads and have a higher traffic volume. Therefore, most state highway agencies tend to pay more emphasis on the pavement conditions on interstate pavements, resulting in a more stringent trigger value.

(c) Standard deviations of historical intervention levels tend to be high compared to their mean values. For example, the standard deviation for IRI can range between 17 to 40 inches/mile for asphalt pavements and 25 to 45 inches/mile for jointed (or jointed-reinforced) concrete pavements, depending on the type of action and functional class of the highway. The relatively high standard deviations can be attributed to two main reasons. First, there is a variety of individual treatments within each treatment category, and each treatment is applied under different pavement conditions. Second, there are other factors such as budget levels, agency policy and local constraints that can affect the historical decision. These factors are not accounted in the development of the intervention levels, hence results in a higher variation.

Historical intervention levels for individual pavement preservation treatments are shown in Table 4.4. Other than the findings presented in the earlier discussion, it can be observed that standard deviations are smaller when compared to the standard deviations presented in Table 4.3. This shows that the higher standard deviations observed in Table 4.3 are partially attributed to the variety of treatments within a treatment category.

Individual treatment intervention levels are determined for both asphalt and jointed (or jointedreinforced) concrete pavements:

(a) For asphalt pavements, pavement maintenance and preservation treatments (such as crack seal, surface treatment and thin overlays) are performed on pavements with relatively good IRI (i.e. less than 80 inches/mile), good PCR (more than 80), rut depths less than 0.25 inch, and exhibit load and 
non-load related cracks of low to moderate severity. This finding is consistent to current recommendations and research findings found in other research studies (Hicks et al., 2000; Zimmerman and Peshkin, 2004; Smith et al., 2008).

(b) For jointed (or jointed-reinforced) concrete pavements, crack seals are performed on pavements with relatively good IRI (i.e. less than 115 inches/mile) and PCR (more than 80) with low severity faulting. Similar criteria is also found for joint repair, with the exception that faulting tends to be moderate. For partial and full-depth repairs, the triggers tend to be more severe than those for crack seals and joint repairs. This is consistent to current recommendations and research findings found in other research studies (Hicks et al., 1997; Smith et al., 2008).

Table 4.3 Historical Intervention Levels for Different Pavement Treatment Categories

(a) Asphalt Pavement

\begin{tabular}{|c|c|c|c|c|c|c|c|}
\hline \multicolumn{2}{|c|}{ Performance Measure } & \multicolumn{6}{|c|}{ Historical Intervention Level } \\
\hline & & \multicolumn{3}{|c|}{ Interstates } & \multicolumn{3}{|c|}{ Non-Interstates } \\
\hline & & $\begin{array}{l}\text { Maintenance } \\
\& \\
\text { Preservation }\end{array}$ & Rehabilitation & Reconstruction & $\begin{array}{l}\text { Maintenance } \\
\& \\
\text { Preservation }\end{array}$ & Rehabilitation & Reconstruction \\
\hline \multirow{2}{*}{$\begin{array}{l}\text { IRI } \\
\text { (inch/mile) }\end{array}$} & Mean & 72.9 & 87.1 & 140.3 & 94.3 & 110.2 & 146.8 \\
\hline & Std Dev & 17.3 & 20.0 & 22.4 & 22.1 & 38.6 & 40.2 \\
\hline \multirow[t]{2}{*}{ PCR } & Mean & 91.2 & 87.8 & 84.0 & 86.0 & 83.9 & 80.8 \\
\hline & Std Dev & 5.8 & 5.5 & 4.1 & 7.1 & 9.3 & 6.4 \\
\hline \multirow{2}{*}{$\begin{array}{l}\text { Load- } \\
\text { Associated } \\
\text { Crack } \\
\text { Severity }\end{array}$} & Mean & 0.92 & 1.13 & 1.27 & 0.93 & 1.24 & 1.36 \\
\hline & Std Dev & 0.64 & 0.65 & 0.68 & 0.65 & 0.73 & 0.75 \\
\hline \multirow{2}{*}{$\begin{array}{l}\text { Non-Load- } \\
\text { Associated } \\
\text { Crack } \\
\text { Severity }\end{array}$} & Mean & 0.81 & 0.83 & 0.85 & 0.85 & 0.93 & 0.98 \\
\hline & Std Dev & 0.41 & 0.52 & 0.57 & 0.45 & 0.53 & 0.57 \\
\hline \multirow{2}{*}{$\begin{array}{l}\text { Rut Depth } \\
\text { (inch) }\end{array}$} & Mean & 0.15 & 0.16 & 0.18 & 0.18 & 0.21 & 0.19 \\
\hline & Std Dev & 0.08 & 0.07 & 0.05 & 0.09 & 0.11 & 0.07 \\
\hline \multicolumn{2}{|l|}{ Sample Size } & 200 & 200 & 30 & 200 & 200 & 30 \\
\hline
\end{tabular}

(b) Concrete Pavement (Jointed or Jointed Reinforced)

\begin{tabular}{|c|c|c|c|c|c|c|c|}
\hline \multirow{3}{*}{\multicolumn{2}{|c|}{ Performance Measure }} & \multicolumn{6}{|c|}{ Historical Intervention Level } \\
\hline & & \multicolumn{3}{|c|}{ Interstates } & \multicolumn{3}{|c|}{ Non-Interstates } \\
\hline & & $\begin{array}{l}\text { Maintenance } \\
\& \\
\text { Preservation }\end{array}$ & Rehabilitation & Reconstruction & $\begin{array}{l}\text { Maintenance } \\
\& \\
\text { Preservation }\end{array}$ & Rehabilitation & Reconstruction \\
\hline \multirow[t]{2}{*}{ IRI (inch/mile) } & Mean & 81.4 & 90.8 & 146.75 & 93.4 & 113.3 & 181.1 \\
\hline & Std Dev & 24.9 & 30.7 & 35.0 & 25.0 & 41.6 & 45.6 \\
\hline \multirow[t]{2}{*}{ PCR } & Mean & 91.8 & 88.3 & 85.5 & 85.5 & 83.4 & 80.6 \\
\hline & Std Dev & 3.5 & 4.7 & 3.2 & 6.5 & 9.8 & 7.6 \\
\hline \multirow{2}{*}{$\begin{array}{l}\text { Load- } \\
\text { Associated } \\
\text { Crack Severity }\end{array}$} & Mean & 0.94 & 1.14 & 1.26 & 0.96 & 1.25 & 1.39 \\
\hline & Std Dev & 0.52 & 0.63 & 0.71 & 0.57 & 0.65 & 0.76 \\
\hline \multirow{2}{*}{$\begin{array}{l}\text { Fault Depth } \\
\text { (inch) }\end{array}$} & Mean & 0.11 & 0.15 & 0.19 & 0.13 & 0.20 & 0.27 \\
\hline & Std Dev & 0.04 & 0.06 & 0.04 & 0.06 & 0.07 & 0.07 \\
\hline \multicolumn{2}{|l|}{ Sample Size } & 200 & 200 & 30 & 200 & 200 & 30 \\
\hline
\end{tabular}


Table 4.4: Historical Pavement Maintenance and Preservation Treatment Intervention Levels

(a) Asphalt Pavement

\begin{tabular}{|c|c|c|c|c|c|c|c|}
\hline \multirow{2}{*}{\multicolumn{2}{|c|}{ Performance Measure }} & \multicolumn{6}{|c|}{ Historical Intervention Level } \\
\hline & & \multicolumn{3}{|c|}{ Interstates } & \multicolumn{3}{|c|}{ Non-Interstates } \\
\hline & & & & & & & \\
\hline & & $\begin{array}{c}\text { Crack } \\
\text { Seal }\end{array}$ & $\begin{array}{l}\text { Surrace } \\
\text { Treatment }\end{array}$ & $\begin{array}{l}\text { Inin PMI } \\
\text { Overlay }\end{array}$ & $\begin{array}{c}\text { Crack } \\
\text { Seal }\end{array}$ & $\begin{array}{l}\text { Surface } \\
\text { Treatment }\end{array}$ & Overlay \\
\hline \multirow[t]{2}{*}{ IRI (inch/mile) } & Mean & 60.9 & 73.5 & 79.9 & 74.6 & 85.4 & 94.3 \\
\hline & Std Dev & 25.4 & 24.5 & 21.1 & 27.5 & 28.9 & 32.7 \\
\hline \multirow[t]{2}{*}{ PCR } & Mean & 88.4 & 93.2 & 90.9 & 80.3 & 83.6 & 86.0 \\
\hline & Std Dev & 5.3 & 6.7 & 4.0 & 8.5 & 8.2 & 7.2 \\
\hline \multirow{2}{*}{$\begin{array}{l}\text { Load-Associated } \\
\text { Crack Severity }\end{array}$} & Mean & 0.9 & 0.9 & 0.9 & 0.9 & 0.9 & 0.9 \\
\hline & Std Dev & 0.8 & 0.4 & 0.7 & 0.7 & 0.5 & 0.5 \\
\hline \multirow{2}{*}{$\begin{array}{l}\text { Non-Load- } \\
\text { Associated Crack } \\
\text { Severity }\end{array}$} & Mean & 0.8 & 0.4 & 0.8 & 0.8 & 0.8 & 0.9 \\
\hline & Std Dev & 0.4 & 0.5 & 0.5 & 0.6 & 0.7 & 0.7 \\
\hline \multirow[t]{2}{*}{ Rut Depth (inch) } & Mean & 0.14 & 0.09 & 0.15 & 0.14 & 0.16 & 0.18 \\
\hline & Std Dev & 0.02 & 0.04 & 0.05 & 0.03 & 0.07 & 0.10 \\
\hline \multicolumn{2}{|l|}{ Sample Size } & 50 & 50 & 100 & 50 & 50 & 100 \\
\hline
\end{tabular}

Note: IRI = International Roughness Index, PCR = Pavement Condition Rating (0-100)

(b) Concrete Pavement (Jointed or Jointed Reinforced)

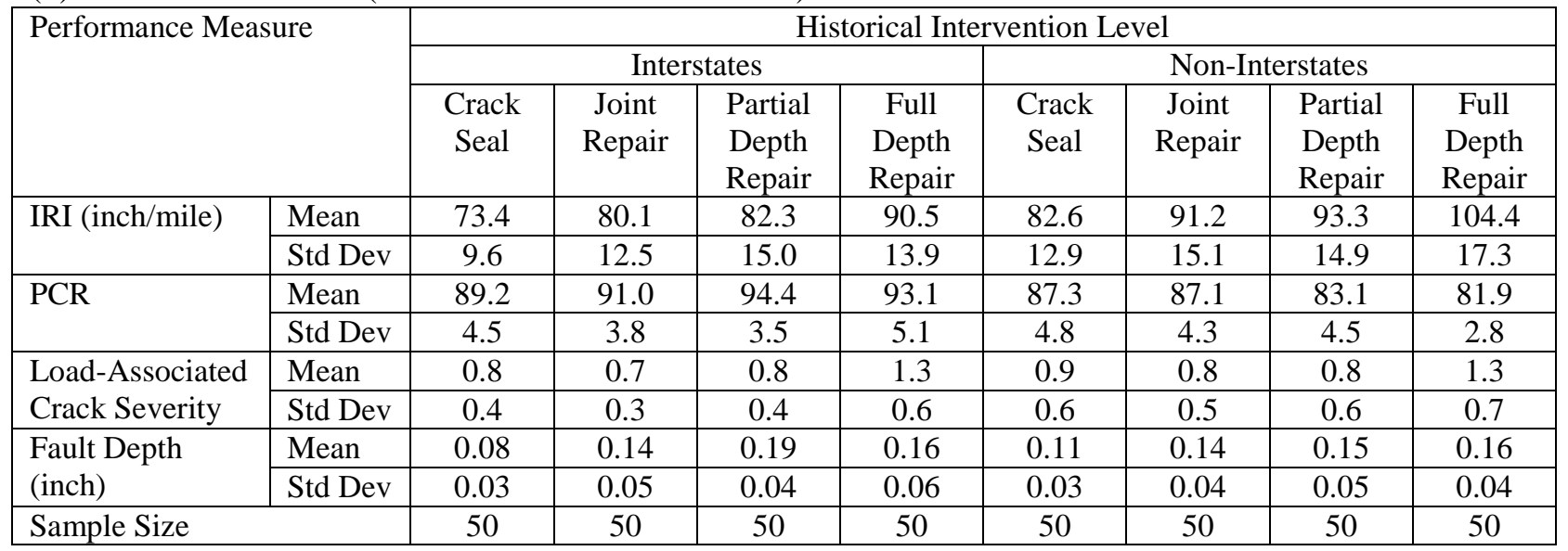

Note: IRI = International Roughness Index, PCR = Pavement Condition Rating (0-100)

\subsection{Determining Pavement Thresholds using Expert Opinions}

Besides the use of information on historical practices, another approach which highway agencies can adopt to evaluate treatment intervention levels is to seek expert opinions. Using the opinions of various pavement experts, decision matrices for pavement treatment selection can then be formulated. This section shall present the procedure to develop decision matrices for pavement treatments, using the data collected in the state of Indiana as an example. The procedure can be further modified by state highway agencies to suit their individual criteria and need. 


\subsubsection{Expert Opinion Survey}

Interviews and surveys were performed to obtain expert opinions on the preferred pavement preservation and rehabilitation treatments. A total of 50 pavement engineers, designers, managers and senior executive staff in Indiana were interviewed in 2008 and each expert was asked to select a set of preferred treatments shown in Tables 4.1 and 4.2. It was assumed in the questionnaire that the experts select treatments which they feel is the best for the pavements with a certain set of pavement conditions, without any budget consideration. This is necessary as any consideration to budget can affect the expert opinion and introduce bias to the treatment choice.

For the ease of soliciting expert opinions in questionnaires, distress categories are used instead of actual values and the classification within each category are shown in Table 4.1. In particular distress identification are made consistent with guidelines laid out in the LTPP manual and the INDOT distress identification manual (INDOT, 1997, 2002; Miller and Bellinger, 2003). Consistent with the LTPP guidelines, cracks are classified into load related and non-load related cracks for asphalt pavements, whereas for jointed (or jointed-reinforced) concrete pavements, only load-related cracks are considered. In particular, chip seals and microsurfacing options are considered in the questionnaire to explore the receptiveness and expert views from the pavement experts in the State.

\subsubsection{Procedure to Determine Decision Matrix for Pavement Treatment Selection}

Decision matrices for preservation and rehabilitation actions can be developed from the expert opinion surveys. To determine the "best" decision for each condition attribute category, the concept of maximum utility (or value) is employed. Let $X_{i}=x_{i}$ where $i=1,2 \ldots I$, be the set of disaggregate pavement attributes and $Y_{j}=y_{j}$ where $j=1,2 \ldots J$, be the set of pavement decisions (which can be pavement treatments or treatment category). Based on the treatment choice selected by each expert during the questionnaire, we can determine the following utilities:

$u\left(y_{i j}\right)=\frac{w_{k} n_{i j k}}{\sum w_{k} n_{i j k}}$

where $u\left(y_{i j}\right)$ is the utility of decision $y_{i j}, w_{k}$ is the weights of each expert $k, n_{i j k}$ is the binary value ( 0 or 1$)$ representing if decision $y_{i j}$ is preferred by expert $k$, and $K$ is the total number of experts interviewed. The determination of the preferred treatment choice can be put in the form of the following optimization problem as defined in Eq. (4.4). 
$\max \quad u \quad y_{i j}$

given $y_{i j} \in X_{i}, Y_{j}$

It can be deduced from Eq. (4.5) that the action that gives the maximum utility is the one that is the most preferred.

\subsubsection{Decision Matrices for Preservation Treatments}

Based on the survey results, the preferred treatment are be evaluated using Eq. (4.4) and (4.5) and expressed in the form of decision matrices. The results of the analyses are described below.

\section{$\underline{\text { Decision Matrices for Pavement Preservation and Rehabilitation Treatments }}$}

Table 4.5 presents the preferred treatment category matrix (in terms of the following options: "do nothing", maintenance and preservation", "rehabilitation" or "reconstruction") for both asphalt and jointed (or jointed-reinforced) concrete pavements.

(a) For asphalt pavements, it was found that:

- As rut, crack and roughness severities increase, the preferred pavement treatment option shifts from "do nothing" to "maintenance and preservation", then to "rehabilitation" and finally "reconstruction". This is bounded by the two extreme cases: "do-nothing" for a pavement with no crack, rut and has excellent IRI and $\mathrm{SN}_{40}$ values; and "reconstruction" for a pavement with high severity cracks and ruts, poor IRI and $\mathrm{SN}_{40}$ values.

- For pavements with poor friction (as indicated by a low FN value), pavement preservation is preferred, unless the pavement has significant structural damage (as indicated by poor IRI, high rut depth or high-severity crack). In this case, rehabilitation or reconstruction is preferred instead.

- There seems to be little difference in preferred pavement treatment between load and non-load related cracks.

(b) For jointed (or jointed-reinforced) concrete pavements, it was found that:

- As fault, crack and roughness severities increase, the preferred pavement treatment shifts from "do nothing" to "maintenance and preservation", then to "rehabilitation" and finally "reconstruction".

- For PCC pavements with poor friction (as indicated by a low FN value), pavement preservation is preferred. Rehabilitation or reconstruction is preferred when the PCC pavements suffer from significant structural deterioration. 
(c) Non-interstate pavements are found to have a lower trigger value than interstate pavements for both asphalt and jointed (or jointed-reinforced) concrete pavements.

Table 4.5: Pavement M, R and R Decision Matrices

(a) Asphalt Pavements

\begin{tabular}{|c|c|c|c|c|c|c|c|c|c|c|c|c|c|c|}
\hline \multirow{2}{*}{\multicolumn{3}{|c|}{ Conditions }} & \multicolumn{6}{|c|}{ Interstates } & \multicolumn{6}{|c|}{ Non Interstates } \\
\hline & & & \multicolumn{2}{|c|}{ Excellent IRI } & \multicolumn{2}{|c|}{ Fair IRI } & \multicolumn{2}{|c|}{ Poor IRI } & \multicolumn{2}{|c|}{ Excellent IRI } & \multicolumn{2}{|c|}{ Fair IRI } & \multicolumn{2}{|c|}{ Poor IRI } \\
\hline & & & $\begin{array}{c}\text { Good } \\
\text { FN }\end{array}$ & $\begin{array}{c}\text { Poor } \\
\text { FN }\end{array}$ & $\begin{array}{c}\text { Good } \\
\text { FN }\end{array}$ & $\begin{array}{c}\text { Poor } \\
\text { FN }\end{array}$ & $\begin{array}{c}\text { Good } \\
\text { FN }\end{array}$ & $\begin{array}{l}\text { Poor } \\
\text { FN }\end{array}$ & $\begin{array}{c}\text { Good } \\
\text { FN }\end{array}$ & $\begin{array}{c}\text { Poor } \\
\text { FN }\end{array}$ & $\begin{array}{c}\text { Good } \\
\text { FN }\end{array}$ & $\begin{array}{c}\text { Poor } \\
\text { FN }\end{array}$ & $\begin{array}{c}\text { Good } \\
\text { FN }\end{array}$ & $\begin{array}{l}\text { Poor } \\
\text { FN }\end{array}$ \\
\hline \multirow{16}{*}{ 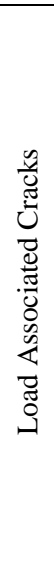 } & \multirow{4}{*}{$\begin{array}{l}\frac{y}{\tilde{J}} \\
\tilde{\pi} \\
\text { z } \\
\text { z }\end{array}$} & No Rut & DN & M\&P & $\mathrm{DN}$ & $\mathrm{M} \& \mathrm{P}$ & $\mathrm{M} \& \mathrm{P}$ & $\mathrm{M} \& \mathrm{P}$ & DN & $\mathrm{M} \& \mathrm{P}$ & $\mathrm{DN}$ & $\mathrm{M} \& \mathrm{P}$ & $\mathrm{DN}$ & $\mathrm{M} \& \mathrm{P}$ \\
\hline & & LS Rut & $\mathrm{DN}$ & $\mathrm{M} \& \mathrm{P}$ & $\mathrm{DN}$ & $\mathrm{M} \& \mathrm{P}$ & $\mathrm{M} \& \mathrm{P}$ & $\mathrm{M} \& \mathrm{P}$ & $\mathrm{DN}$ & $\mathrm{M} \& \mathrm{P}$ & $\mathrm{DN}$ & $\mathrm{M} \& \mathrm{P}$ & $\mathrm{M} \& \mathrm{P}$ & $\mathrm{M} \& \mathrm{P}$ \\
\hline & & MS Rut & M\&P & $\mathrm{M} \& \mathrm{P}$ & $\mathrm{M} \& \mathrm{P}$ & $\mathrm{M} \& \mathrm{P}$ & $\mathrm{M} \& \mathrm{P}$ & $\mathrm{M} \& \mathrm{P}$ & $\mathrm{DN}$ & $\mathrm{M} \& \mathrm{P}$ & $\mathrm{M} \& \mathrm{P}$ & $\mathrm{M} \& \mathrm{P}$ & M\&P & $\mathrm{M} \& \mathrm{P}$ \\
\hline & & HS Rut & $\mathrm{M} \& \mathrm{P}$ & $\mathrm{M} \& \mathrm{P}$ & $\mathrm{M} \& \mathrm{P}$ & $\mathrm{M} \& \mathrm{P}$ & $\mathrm{M} \& \mathrm{P}$ & $\mathrm{M} \& \mathrm{P}$ & $\mathrm{M} \& \mathrm{P}$ & $\mathrm{M} \& \mathrm{P}$ & $\mathrm{M} \& \mathrm{P}$ & $\mathrm{M} \& \mathrm{P}$ & $\mathrm{M} \& \mathrm{P}$ & $\mathrm{M} \& \mathrm{P}$ \\
\hline & \multirow{4}{*}{$\Omega$} & No Rut & DN & $\mathrm{M} \& \mathrm{P}$ & $\mathrm{M} \& \mathrm{P}$ & $\mathrm{M} \& \mathrm{P}$ & $\mathrm{M} \& \mathrm{P}$ & $\mathrm{M} \& \mathrm{P}$ & DN & $\mathrm{M} \& \mathrm{P}$ & $\mathrm{M} \& \mathrm{P}$ & $\mathrm{M} \& \mathrm{P}$ & $\mathrm{M} \& \mathrm{P}$ & $\mathrm{M} \& \mathrm{P}$ \\
\hline & & LS Rut & $\mathrm{M} \& \mathrm{P}$ & $\mathrm{M} \& \mathrm{P}$ & $\mathrm{M} \& \mathrm{P}$ & $\mathrm{M} \& \mathrm{P}$ & $\mathrm{M} \& \mathrm{P}$ & $\mathrm{M} \& \mathrm{P}$ & $\mathrm{DN}$ & $\mathrm{M} \& \mathrm{P}$ & $\mathrm{M} \& \mathrm{P}$ & $\mathrm{M} \& \mathrm{P}$ & $\mathrm{M} \& \mathrm{P}$ & $\mathrm{M} \& \mathrm{P}$ \\
\hline & & MS Rut & $\mathrm{M} \& \mathrm{P}$ & $\mathrm{M} \& \mathrm{P}$ & $\mathrm{M} \& \mathrm{P}$ & M\&P & $\mathrm{M} \& \mathrm{P}$ & $\mathrm{M} \& \mathrm{P}$ & $\mathrm{M} \& \mathrm{P}$ & $\mathrm{M} \& \mathrm{P}$ & M\&P & $\mathrm{M} \& \mathrm{P}$ & $\mathrm{M} \& \mathrm{P}$ & $\mathrm{M} \& \mathrm{P}$ \\
\hline & & HS Rut & $1 \& \mathrm{P}$ & $\mathrm{M} \& \mathrm{P}$ & $\mathrm{M} \& \mathrm{P}$ & $\mathrm{M} \& \mathrm{P}$ & $1 \& \mathrm{P}$ & $\mathrm{M} \& \mathrm{P}$ & $\mathrm{M} \& \mathrm{P}$ & $1 \& \mathrm{P}$ & $\mathrm{M} \& \mathrm{P}$ & $\mathrm{M} \& \mathrm{P}$ & $\mathrm{M} \& \mathrm{P}$ & $\mathrm{M} \& \mathrm{P}$ \\
\hline & \multirow{4}{*}{$\sum_{\Sigma}^{\mathscr{\Sigma}}$} & No Rut & $\& \mathrm{P}$ & $\mathrm{M} \& \mathrm{P}$ & $\mathrm{M} \& \mathrm{P}$ & $\mathrm{M} \& \mathrm{P}$ & $\mathrm{M} \& \mathrm{P}$ & $\mathrm{M} \& \mathrm{P}$ & $\mathrm{I} \& \mathrm{P}$ & $\mathrm{I} \& \mathrm{P}$ & 1\&P & $1 \& \mathrm{P}$ & I\&P & $\mathrm{M} \& \mathrm{P}$ \\
\hline & & LS Rut & $\mathrm{M} \& \mathrm{P}$ & $\mathrm{M} \& \mathrm{P}$ & $\mathrm{M} \& \mathrm{P}$ & $\mathrm{M} \& \mathrm{P}$ & $\mathrm{M} \& \mathrm{P}$ & $\mathrm{M} \& \mathrm{P}$ & $\mathrm{M} \& \mathrm{P}$ & $\mathrm{M} \& \mathrm{P}$ & $\mathrm{M} \& \mathrm{P}$ & $\mathrm{M} \& \mathrm{P}$ & $\mathrm{M} \& \mathrm{P}$ & $\mathrm{M} \& \mathrm{P}$ \\
\hline & & MS Rut & M\&P & $\mathrm{M} \& \mathrm{P}$ & $\mathrm{M} \& \mathrm{P}$ & M\&P & RH & $\mathrm{RH}$ & $\mathrm{M} \& \mathrm{P}$ & $\mathrm{M} \& \mathrm{P}$ & $\mathrm{M} \& \mathrm{P}$ & $\mathrm{M} \& \mathrm{P}$ & RH & $\mathrm{RH}$ \\
\hline & & HS Rut & $\mathrm{M} \& \mathrm{P}$ & $\mathrm{M} \& \mathrm{P}$ & $\mathrm{RH}$ & RH & RH & $\mathrm{RH}$ & $\mathrm{M} \& \mathrm{P}$ & $\mathrm{M} \& \mathrm{P}$ & RH & RH & RH & RH \\
\hline & \multirow{4}{*}{ 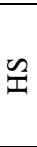 } & No Rut & $\mathrm{M} \& \mathrm{P}$ & $\mathrm{M} \& \mathrm{P}$ & $\mathrm{M} \& \mathrm{P}$ & M\&P & $\mathrm{RH}$ & $\mathrm{RH}$ & $\mathrm{M} \& \mathrm{P}$ & $\mathrm{M} \& \mathrm{P}$ & $\mathrm{M} \& \mathrm{P}$ & $\mathrm{M} \& \mathrm{P}$ & $\mathrm{RH}$ & RH \\
\hline & & LS Rut & $\mathrm{M} \& \mathrm{P}$ & $\mathrm{M} \& \mathrm{P}$ & $\mathrm{RH}$ & RH & $\mathrm{RH}$ & $\mathrm{RH}$ & $\mathrm{M} \& \mathrm{P}$ & $\mathrm{M} \& \mathrm{P}$ & $\mathrm{RH}$ & $\mathrm{RH}$ & RH & $\mathrm{RH}$ \\
\hline & & MS Rut & $\mathrm{RH}$ & $\mathrm{RH}$ & $\mathrm{RH}$ & RH & RH & RH & RH & RH & RH & RH & $\mathrm{RH}$ & $\mathrm{RH}$ \\
\hline & & HS Rut & $\mathrm{RH}$ & RH & $\mathrm{RC}$ & $\mathrm{RC}$ & $\mathrm{RC}$ & $\mathrm{RC}$ & $\mathrm{RH}$ & $\mathrm{RH}$ & $\mathrm{RC}$ & $\mathrm{RC}$ & $\mathrm{RC}$ & $\mathrm{RC}$ \\
\hline \multirow{16}{*}{ 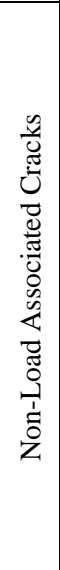 } & \multirow{4}{*}{ 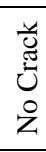 } & No Rut & $\mathrm{DN}$ & $\mathrm{M} \& \mathrm{P}$ & $\mathrm{DN}$ & $\mathrm{M} \& \mathrm{P}$ & $\mathrm{M} \& \mathrm{P}$ & $\mathrm{M} \& \mathrm{P}$ & $\mathrm{DN}$ & $\mathrm{M} \& \mathrm{P}$ & $\mathrm{DN}$ & $\mathrm{M} \& \mathrm{P}$ & $\mathrm{DN}$ & $\mathrm{M} \& \mathrm{P}$ \\
\hline & & LS Rut & DN & $\mathrm{M} \& \mathrm{P}$ & $\mathrm{DN}$ & M\&P & $\mathrm{M} \& \mathrm{P}$ & $\mathrm{M} \& \mathrm{P}$ & DN & $\mathrm{M} \& \mathrm{P}$ & DN & M\&P & M\&P & $\mathrm{M} \& \mathrm{P}$ \\
\hline & & MS Rut & M\&P & $\mathrm{M} \& \mathrm{P}$ & M\&P & M\&P & M\&P & $\mathrm{M} \& \mathrm{P}$ & $\mathrm{DN}$ & M\&P & M\&P & M\&P & M\&P & M\&P \\
\hline & & HS Rut & $\mathrm{M} \& \mathrm{P}$ & $\mathrm{M} \& \mathrm{P}$ & $\mathrm{M} \& \mathrm{P}$ & $\mathrm{M} \& \mathrm{P}$ & $\mathrm{M} \& \mathrm{P}$ & $\mathrm{M} \& \mathrm{P}$ & $\mathrm{M} \& \mathrm{P}$ & $\mathrm{M} \& \mathrm{P}$ & $\mathrm{M} \& \mathrm{P}$ & $\mathrm{M} \& \mathrm{P}$ & $\mathrm{M} \& \mathrm{P}$ & $\mathrm{M} \& \mathrm{P}$ \\
\hline & \multirow{4}{*}{ 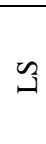 } & No Rut & DN & $\mathrm{M} \& \mathrm{P}$ & $\mathrm{M} \& \mathrm{P}$ & $\mathrm{M} \& \mathrm{P}$ & $\mathrm{M} \& \mathrm{P}$ & $\mathrm{M} \& \mathrm{P}$ & $\mathrm{DN}$ & $\mathrm{M} \& \mathrm{P}$ & $\mathrm{M} \& \mathrm{P}$ & $\mathrm{M} \& \mathrm{P}$ & $\mathrm{M} \& \mathrm{P}$ & $\mathrm{M} \& \mathrm{P}$ \\
\hline & & LS Rut & $\mathrm{M} \& \mathrm{P}$ & $\mathrm{M} \& \mathrm{P}$ & $\mathrm{M} \& \mathrm{P}$ & $\mathrm{M} \& \mathrm{P}$ & $\mathrm{M} \& \mathrm{P}$ & $\mathrm{M} \& \mathrm{P}$ & $\mathrm{DN}$ & $\mathrm{M} \& \mathrm{P}$ & $\mathrm{M} \& \mathrm{P}$ & $\mathrm{M} \& \mathrm{P}$ & $\mathrm{M} \& \mathrm{P}$ & $\mathrm{M} \& \mathrm{P}$ \\
\hline & & MS Rut & $\mathrm{M} \& \mathrm{P}$ & $\mathrm{M} \& \mathrm{P}$ & $\mathrm{M} \& \mathrm{P}$ & $\mathrm{M} \& \mathrm{P}$ & $\mathrm{M} \& \mathrm{P}$ & $\mathrm{M} \& \mathrm{P}$ & $\mathrm{M} \& \mathrm{P}$ & $\mathrm{M} \& \mathrm{P}$ & $\mathrm{M} \& \mathrm{P}$ & $\mathrm{M} \& \mathrm{P}$ & $\mathrm{M} \& \mathrm{P}$ & $\mathrm{M} \& \mathrm{P}$ \\
\hline & & HS Rut & M\&P & $\mathrm{M} \& \mathrm{P}$ & M\&P & M\&P & $\mathrm{M} \& \mathrm{P}$ & $\mathrm{M} \& \mathrm{P}$ & $\mathrm{M} \& \mathrm{P}$ & M\&P & M\&P & $\mathrm{M} \& \mathrm{P}$ & M\&P & $\mathrm{M} \& \mathrm{P}$ \\
\hline & \multirow{4}{*}{$\sum$} & No Rut & $\mathrm{M} \& \mathrm{P}$ & $\mathrm{M} \& \mathrm{P}$ & $\mathrm{M} \& \mathrm{P}$ & M\&P & $\mathrm{M} \& \mathrm{P}$ & $\mathrm{M} \& \mathrm{P}$ & $\mathrm{M} \& \mathrm{P}$ & $\mathrm{M} \& \mathrm{P}$ & M\&P & $\mathrm{M} \& \mathrm{P}$ & M\&P & $\mathrm{M} \& \mathrm{P}$ \\
\hline & & LS Rut & M\&P & $\mathrm{M} \& \mathrm{P}$ & $\mathrm{M} \& \mathrm{P}$ & M\&P & $\mathrm{M} \& \mathrm{P}$ & $\mathrm{M} \& \mathrm{P}$ & M\&P & $\mathrm{M} \& \mathrm{P}$ & M\&P & M\&P & M\&P & M\&P \\
\hline & & MS Rut & $\mathrm{M} \& \mathrm{P}$ & $\mathrm{M} \& \mathrm{P}$ & $\mathrm{M} \& \mathrm{P}$ & $\mathrm{M} \& \mathrm{P}$ & RH & $\mathrm{RH}$ & $\mathrm{M} \& \mathrm{P}$ & $\mathrm{M} \& \mathrm{P}$ & $\mathrm{M} \& \mathrm{P}$ & $\mathrm{M} \& \mathrm{P}$ & RH & $\mathrm{RH}$ \\
\hline & & HS Rut & $\mathrm{M} \& \mathrm{P}$ & $\mathrm{M} \& \mathrm{P}$ & $\mathrm{RH}$ & RH & RH & RH & $\mathrm{M} \& \mathrm{P}$ & $\mathrm{M} \& \mathrm{P}$ & RH & $\mathrm{RH}$ & RH & $\mathrm{RH}$ \\
\hline & \multirow{4}{*}{ I } & No Rut & $\mathrm{M} \& \mathrm{P}$ & $\mathrm{M} \& \mathrm{P}$ & $\mathrm{M} \& \mathrm{P}$ & M\&P & RH & RH & $\mathrm{M} \& \mathrm{P}$ & $\mathrm{M} \& \mathrm{P}$ & $\mathrm{M} \& \mathrm{P}$ & $\mathrm{M} \& \mathrm{P}$ & RH & RH \\
\hline & & LS Rut & M\&P & $\mathrm{M} \& \mathrm{P}$ & $\mathrm{RH}$ & RH & $\mathrm{RH}$ & RH & M\&P & $\mathrm{M} \& \mathrm{P}$ & $\mathrm{RH}$ & $\mathrm{RH}$ & RH & RH \\
\hline & & MS Rut & $\mathrm{RH}$ & RH & $\mathrm{RH}$ & RH & $\overline{\mathrm{RH}}$ & $\mathrm{RH}$ & $\mathrm{RH}$ & RH & $\mathrm{RH}$ & $\mathrm{RH}$ & RH & $\mathrm{RH}$ \\
\hline & & HS Rut & $\mathrm{RH}$ & RH & $\mathrm{RC}$ & $\mathrm{RC}$ & $\mathrm{RC}$ & $\mathrm{RC}$ & $\mathrm{RH}$ & RH & $\mathrm{RC}$ & $\mathrm{RC}$ & $\mathrm{RC}$ & $\mathrm{RC}$ \\
\hline
\end{tabular}

Note:

IRI = International Roughness Index, $\mathrm{SN}_{40}=$ Skid Number

LS = Low Severity, MS = Medium Severity, HS = High Severity

$\mathrm{M} \& \mathrm{P}=$ Maintenance and Preservation, $\mathrm{RH}=$ Rehabilitation, $\mathrm{RC}=$ Reconstruction

Refer to Table 2 for treatments in each category 
Table 4.5: Pavement M, R and R Decision Matrices (cont'd)

(b) Concrete Pavement (Jointed or Jointed Reinforced)

\begin{tabular}{|c|c|c|c|c|c|c|c|c|c|c|c|c|c|c|}
\hline \multirow{2}{*}{\multicolumn{3}{|c|}{ Conditions }} & \multicolumn{6}{|c|}{ Interstates } & \multicolumn{6}{|c|}{ Non Interstates } \\
\hline & & & \multicolumn{2}{|c|}{ Excellent IRI } & \multicolumn{2}{|c|}{ Fair IRI } & \multicolumn{2}{|c|}{ Poor IRI } & \multicolumn{2}{|c|}{ Excellent IRI } & \multicolumn{2}{|c|}{ Fair IRI } & \multicolumn{2}{|c|}{ Poor IRI } \\
\hline & & & $\begin{array}{c}\text { Good } \\
\text { FN }\end{array}$ & $\begin{array}{c}\text { Poor } \\
\text { FN }\end{array}$ & $\begin{array}{c}\text { Good } \\
\text { FN }\end{array}$ & $\begin{array}{c}\text { Poor } \\
\text { FN }\end{array}$ & $\begin{array}{c}\text { Good } \\
\text { FN }\end{array}$ & $\begin{array}{c}\text { Poor } \\
\text { FN }\end{array}$ & $\begin{array}{c}\text { Good } \\
\text { FN }\end{array}$ & $\begin{array}{c}\text { Poor } \\
\text { FN }\end{array}$ & $\begin{array}{c}\text { Good } \\
\text { FN }\end{array}$ & $\begin{array}{c}\text { Poor } \\
\text { FN }\end{array}$ & $\begin{array}{c}\text { Good } \\
\text { FN }\end{array}$ & $\begin{array}{c}\text { Poor } \\
\text { FN }\end{array}$ \\
\hline \multirow{16}{*}{ 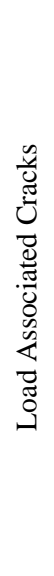 } & \multirow{4}{*}{ 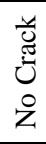 } & No Fault & DN & $\mathrm{M} \& \mathrm{P}$ & N.A. & N.A. & N.A. & N.A. & $\mathrm{DN}$ & $\mathrm{M} \& \mathrm{P}$ & N.A. & N.A. & N.A. & N.A. \\
\hline & & LS Fault & $\mathrm{DN}$ & $\mathrm{M} \& \mathrm{P}$ & $\mathrm{DN}$ & M\&P & N.A. & N.A. & $\mathrm{DN}$ & $\mathrm{M} \& \mathrm{P}$ & $\mathrm{DN}$ & M\&P & N.A. & N.A. \\
\hline & & MS Fault & $\mathrm{M} \& \mathrm{P}$ & $\mathrm{M} \& \mathrm{P}$ & $\mathrm{M} \& \mathrm{P}$ & $\mathrm{M} \& \mathrm{P}$ & $\mathrm{M} \& \mathrm{P}$ & $\mathrm{M} \& \mathrm{P}$ & $\mathrm{DN}$ & $\mathrm{M} \& \mathrm{P}$ & $\mathrm{M} \& \mathrm{P}$ & $\mathrm{M} \& \mathrm{P}$ & $\mathrm{M} \& \mathrm{P}$ & $\mathrm{M} \& \mathrm{P}$ \\
\hline & & SS Fault & N.A. & N.A. & $\mathrm{M} \& \mathrm{P}$ & M\&P & M\&P & M\&P & N.A. & N.A. & M\&P & M\&P & $\mathrm{M} \& \mathrm{P}$ & M\&P \\
\hline & \multirow{4}{*}{$\sqrt{3}$} & No Fault & $\mathrm{DN}$ & $\mathrm{M} \& \mathrm{P}$ & N.A. & N.A. & N.A. & N.A. & $\mathrm{DN}$ & M\&P & N.A. & N.A. & N.A. & N.A. \\
\hline & & LS Fault & $\mathrm{M} \& \mathrm{P}$ & M\&P & M\&P & M\&P & N.A. & N.A. & M\&P & M\&P & M\&P & M\&P & N.A. & N.A. \\
\hline & & MS Fault & $\mathrm{M} \& \mathrm{P}$ & $\mathrm{M} \& \mathrm{P}$ & $\mathrm{M} \& \mathrm{P}$ & $\mathrm{M} \& \mathrm{P}$ & $\mathrm{M} \& \mathrm{P}$ & M\&P & $\mathrm{M} \& \mathrm{P}$ & M\&P & $\mathrm{M} \& \mathrm{P}$ & M\&P & $\mathrm{M} \& \mathrm{P}$ & M\&P \\
\hline & & SS Fault & N.A. & N.A. & $\mathrm{M} \& \mathrm{P}$ & $\mathrm{M} \& \mathrm{P}$ & RH & RH & N.A. & N.A. & $\mathrm{M} \& \mathrm{P}$ & $\mathrm{M} \& \mathrm{P}$ & $\mathrm{RH}$ & $\mathrm{RH}$ \\
\hline & \multirow{4}{*}{$\sum_{\Sigma}^{\infty}$} & No Fault & $\mathrm{M} \& \mathrm{P}$ & M\&P & N.A. & N.A. & N.A. & N.A. & $\mathrm{M} \& \mathrm{P}$ & $\mathrm{M} \& \mathrm{P}$ & N.A. & N.A. & N.A. & N.A. \\
\hline & & LS Fault & M\&P & $\mathrm{M} \& \mathrm{P}$ & M\&P & M\&P & N.A. & N.A. & $\mathrm{M} \& \mathrm{P}$ & $\mathrm{M} \& \mathrm{P}$ & $\mathrm{M} \& \mathrm{P}$ & M\&P & N.A. & N.A. \\
\hline & & MS Fault & $\mathrm{M} \& \mathrm{P}$ & $\mathrm{M} \& \mathrm{P}$ & $\mathrm{M} \& \mathrm{P}$ & $\mathrm{M} \& \mathrm{P}$ & RH & $\mathrm{RH}$ & $\mathrm{M} \& \mathrm{P}$ & $\mathrm{M} \& \mathrm{P}$ & $\mathrm{M} \& \mathrm{P}$ & $\mathrm{M} \& \mathrm{P}$ & $\mathrm{RH}$ & $\mathrm{RH}$ \\
\hline & & SS Fault & N.A. & N.A. & $\mathrm{RH}$ & RH & $\mathrm{RC}$ & $\mathrm{RC}$ & N.A. & N.A. & $\mathrm{RH}$ & RH & $\mathrm{RC}$ & $\mathrm{RC}$ \\
\hline & \multirow{4}{*}{$\approx$} & No Fault & M\&P & M\&P & N.A. & N.A. & N.A. & N.A. & $\mathrm{M} \& \mathrm{P}$ & M\&P & N.A. & N.A. & N.A. & N.A. \\
\hline & & LS Fault & M\&P & $\mathrm{M} \& \mathrm{P}$ & RH & RH & RH & $\mathrm{RH}$ & $\mathrm{M} \& \mathrm{P}$ & $\mathrm{M} \& \mathrm{P}$ & $\mathrm{RH}$ & $\mathrm{RH}$ & RH & $\mathrm{RH}$ \\
\hline & & MS Fault & N.A. & N.A. & $\mathrm{RH}$ & RH & $\mathrm{RC}$ & $\mathrm{RC}$ & N.A. & N.A. & $\mathrm{RH}$ & RH & $\mathrm{RC}$ & $\mathrm{RC}$ \\
\hline & & SS Fault & N.A. & N.A. & N.A. & N.A. & $\mathrm{RC}$ & $\mathrm{RC}$ & N.A. & N.A. & N.A. & N.A. & $\mathrm{RC}$ & $\mathrm{RC}$ \\
\hline
\end{tabular}

Note:

IRI = International Roughness Index, $\mathrm{SN}_{40}=$ Skid Number

LS = Low Severity, MS = Medium Severity, HS = High Severity

N.A. refers to infeasible combination of pavement conditions

$\mathrm{M} \& \mathrm{P}=$ Maintenance and Preservation, $\mathrm{RH}=$ Rehabilitation, $\mathrm{RC}=$ Reconstruction

Refer to Table 2 for treatments in each category

Tables 4.6 and 4.7 illustrate the treatment decision matrices for both asphalt and PCC pavements respectively. These matrices could be applied in the network level PMS to decide the type of treatment that can be applied to a highway segment, given a particular combination of pavement conditions. The below observations can be made:

(a) For asphalt pavements (Table 4.6):

- Crack seals are preferred on pavements with: at least a fair IRI, low rut severity and at most a medium crack severity.

- Microsurfacing may be used for the texturing, sealing and filling of ruts. It is preferred when the pavement has at least a fair IRI, cracks and ruts are of at most moderate severity.

- Chip seals are only used on non-interstate pavements with limited traffic to improve friction. It is only applied when IRI is at least fair, rut is at most of moderate severity, and friction is poor.

- In general, thin overlays are used on pavements with: at most cracks of moderate severity, ruts of at most moderate severity and on pavement with at most fair IRI. For pavements with poor IRI, the treatment is applied only if the crack and rut severities are low. Besides, thin overlays are used as a preferred treatment for pavements with poor friction, unless the pavement has significant structural deterioration. 
Table 4.6: Treatment Selection Matrices for Asphalt Pavements

\begin{tabular}{|c|c|c|c|c|c|c|c|c|c|c|c|c|c|c|}
\hline \multirow{2}{*}{\multicolumn{3}{|c|}{ Conditions }} & \multicolumn{6}{|c|}{ Interstates } & \multicolumn{6}{|c|}{ Non Interstates } \\
\hline & & & \multicolumn{2}{|c|}{ Excellent IRI } & \multicolumn{2}{|c|}{ Fair IRI } & \multicolumn{2}{|c|}{ Poor IRI } & \multicolumn{2}{|c|}{ Excellent IRI } & \multicolumn{2}{|c|}{ Fair IRI } & \multicolumn{2}{|c|}{ Poor IRI } \\
\hline & & & $\begin{array}{c}\text { Good } \\
\text { FN }\end{array}$ & $\begin{array}{c}\text { Poor } \\
\text { FN }\end{array}$ & $\begin{array}{c}\text { Good } \\
\text { FN }\end{array}$ & $\begin{array}{l}\text { Poor } \\
\text { FN }\end{array}$ & $\begin{array}{c}\text { Good } \\
\text { FN }\end{array}$ & $\begin{array}{l}\text { Poor } \\
\text { FN }\end{array}$ & $\begin{array}{c}\text { Good } \\
\text { FN }\end{array}$ & $\begin{array}{l}\text { Poor } \\
\text { FN }\end{array}$ & $\begin{array}{c}\text { Good } \\
\text { FN }\end{array}$ & $\begin{array}{c}\text { Poor } \\
\text { FN }\end{array}$ & $\begin{array}{c}\text { Good } \\
\text { FN }\end{array}$ & $\begin{array}{c}\text { Poor } \\
\text { FN }\end{array}$ \\
\hline \multirow{16}{*}{ 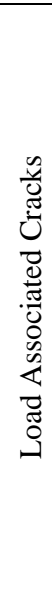 } & \multirow{4}{*}{ 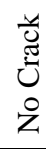 } & No Rut & $\mathrm{DN}$ & TOL & $\mathrm{DN}$ & TOL & TOL & TOL & $\mathrm{DN}$ & $\mathrm{CHP}$ & $\mathrm{DN}$ & $\mathrm{CHP}$ & $\mathrm{DN}$ & TOL \\
\hline & & LS Rut & $\mathrm{DN}$ & TOL & $\mathrm{DN}$ & TOL & TOL & TOL & $\mathrm{DN}$ & CHP & $\mathrm{DN}$ & CHP & CRX & TOL \\
\hline & & MS Rut & CRX & TOL & CRX & TOL & TOL & TOL & $\mathrm{DN}$ & CRX & CRX & CRX & CRX & TOL \\
\hline & & SS Rut & CRX & TOL & CRX & TOL & TOL & TOL & CRX & CRX & CRX & TOL & TOL & TOL \\
\hline & \multirow{4}{*}{ 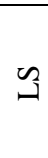 } & No Rut & $\mathrm{DN}$ & TOL & CRX & TOL & TOL & TOL & $\mathrm{DN}$ & $\mathrm{CHP}$ & CRX & $\mathrm{CHP}$ & CRX & TOL \\
\hline & & LS Rut & CRX & TOL & CRX & TOL & TOL & TOL & $\mathrm{DN}$ & CHP & CRX & CHP & CRX & TOL \\
\hline & & MS Rut & CRX & TOL & $\mathrm{CRX}$ & TOL & TOL & TOL & CRX & CRX & CRX & CRX & TOL & TOL \\
\hline & & SS Rut & CRX & TOL & TOL & TOL & TOL & TOL & CRX & TOL & CRX & TOL & TOL & TOL \\
\hline & \multirow{4}{*}{ 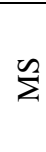 } & No Rut & CRX & TOL & CRX & TOL & TOL & TOL & CRX & CHP & CRX & CHP & TOL & TOL \\
\hline & & LS Rut & CRX & TOL & CRX & TOL & TOL & TOL & CRX & CHP & CRX & CHP & TOL & TOL \\
\hline & & MS Rut & CRX & TOL & TOL & TOL & SOL & SOL & CRX & CRX & TOL & TOL & TOL & TOL \\
\hline & & SS Rut & TOL & TOL & FOL & FOL & SOL & SOL & TOL & TOL & FOL & FOL & SOL & SOL \\
\hline & \multirow{4}{*}{$\approx$} & No Rut & CRX & TOL & TOL & TOL & FOL & FOL & CRX & TOL & TOL & TOL & FOL & FOL \\
\hline & & LS Rut & TOL & TOL & FOL & FOL & SOL & SOL & TOL & TOL & FOL & FOL & FOL & FOL \\
\hline & & MS Rut & FOL & FOL & SOL & SOL & ARP & ARP & FOL & FOL & SOL & SOL & SOL & SOL \\
\hline & & SS Rut & SOL & SOL & ARP & ARP & ARP & ARP & SOL & SOL & ARP & ARP & ARP & ARP \\
\hline
\end{tabular}

(b) For jointed (or jointed-reinforced) concrete pavements (Table 4.7):

- Crack seals are preferred on pavements with: at least a fair IRI, low fault severity and at most a medium crack severity.

- Joint-bump repair and load transfer retrofitting, and diamond grinding is preferred when faulting is at most of moderate severity and the IRI is at least fair. In addition, diamond grinding is also a preferred treatment when friction is poor.

- Partial and full depth-repairs are applied on jointed (or jointed-reinforced) concrete pavements with at most moderate fault and crack severities.

Table 4.8 compares the intervention levels obtained from the two procedures. It can be seen from the table that both procedures yield similar results for crack seals and thin overlays on asphalt pavements; and crack seals, joint repair, shallow depth and full depth patching on jointed (or jointed-reinforced) concrete pavements. This indicates the level of consistency between current agency perceptions and practice. The same observations can also be made when compared to the state of practice (Hicks et al., 1997, 2000; Zimmerman and Peskin, 2004; Smith et al., 2008), indicating that our findings are consistent with commonly-used values in the literature. 
Table 4.7: Treatment Selection Matrices for Jointed or Jointed-Reinforced Concrete Pavements

\begin{tabular}{|c|c|c|c|c|c|c|c|c|c|c|c|c|c|c|}
\hline \multicolumn{3}{|c|}{ Conditions } & \multicolumn{6}{|c|}{ Interstates } & \multicolumn{6}{|c|}{ Non Interstates } \\
\hline & & & \multicolumn{2}{|c|}{ Excellent IRI } & \multicolumn{2}{|c|}{ Fair IRI } & \multicolumn{2}{|c|}{ Poor IRI } & \multicolumn{2}{|c|}{ Excellent IRI } & \multicolumn{2}{|c|}{ Fair IRI } & \multicolumn{2}{|c|}{ Poor IRI } \\
\hline & & & $\begin{array}{c}\text { Good } \\
\text { FN }\end{array}$ & $\begin{array}{c}\text { Poor } \\
\text { FN }\end{array}$ & $\begin{array}{c}\text { Good } \\
\text { FN }\end{array}$ & $\begin{array}{c}\text { Poor } \\
\text { FN }\end{array}$ & $\begin{array}{c}\text { Good } \\
\text { FN }\end{array}$ & $\begin{array}{c}\text { Poor } \\
\text { FN }\end{array}$ & $\begin{array}{c}\text { Good } \\
\text { FN }\end{array}$ & $\begin{array}{c}\text { Poor } \\
\text { FN }\end{array}$ & $\begin{array}{c}\text { Good } \\
\text { FN }\end{array}$ & $\begin{array}{c}\text { Poor } \\
\text { FN }\end{array}$ & $\begin{array}{c}\text { Good } \\
\text { FN }\end{array}$ & $\begin{array}{c}\text { Poor } \\
\text { FN }\end{array}$ \\
\hline \multirow{16}{*}{ 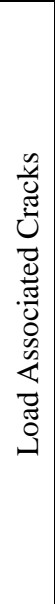 } & \multirow{4}{*}{ 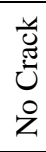 } & No Fault & DN & GRD & N.A. & N.A. & N.A. & N.A. & DN & GRD & N.A. & N.A. & N.A. & N.A. \\
\hline & & LS Fault & $\mathrm{DN}$ & GRD & GRD & GRD & N.A. & N.A. & $\mathrm{DN}$ & GRD & GRD & GRD & N.A. & N.A. \\
\hline & & MS Fault & GRD & GRD & GRD & GRD & PFD & PFD & $\mathrm{DN}$ & GRD & GRD & GRD & GRD & GRD \\
\hline & & SS Fault & N.A. & N.A. & GRD & GRD & PFD & PFD & N.A. & N.A. & GRD & GRD & PFD & PFD \\
\hline & \multirow{4}{*}{ 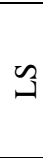 } & No Fault & $\mathrm{DN}$ & GRD & N.A. & N.A. & N.A. & N.A. & $\overline{\mathrm{DN}}$ & GRD & N.A. & N.A. & N.A. & N.A. \\
\hline & & LS Fault & CRX & GRD & CRX & GRD & N.A. & N.A. & CRX & GRD & CRX & GRD & N.A. & N.A. \\
\hline & & MS Fault & GRD & GRD & GRD & GRD & PFD & PFD & GRD & GRD & GRD & GRD & PFD & PFD \\
\hline & & SS Fault & N.A. & N.A. & GRD & GRD & SLR & SLR & N.A. & N.A. & GRD & GRD & SLR & SLR \\
\hline & \multirow{4}{*}{$\sum^{2}$} & No Fault & CRX & GRD & N.A. & N.A. & N.A. & N.A. & CRX & GRD & N.A. & N.A. & N.A. & N.A. \\
\hline & & LS Fault & CRX & GRD & PFD & PFD & N.A. & N.A. & CRX & GRD & PFD & PFD & N.A. & N.A. \\
\hline & & MS Fault & GRD & GRD & PFD & PFD & C\&S & $\mathrm{C} \& \mathrm{~S}$ & GRD & GRD & PFD & PFD & SLR & SLR \\
\hline & & SS Fault & N.A. & N.A. & SLR & SLR & CRP & CRP & N.A. & N.A. & $\mathrm{C} \& \mathrm{~S}$ & $\mathrm{C} \& \mathrm{~S}$ & CRP & CRP \\
\hline & \multirow{4}{*}{$\approx$} & No Fault & CRX & GRD & N.A. & N.A. & N.A. & N.A. & CRX & GRD & N.A. & N.A. & N.A. & N.A. \\
\hline & & LS Fault & CRX & GRD & SOL & SOL & $\mathrm{C} \& \mathrm{~S}$ & $\mathrm{C} \& \mathrm{~S}$ & CRX & GRD & SOL & SOL & SLR & SLR \\
\hline & & MS Fault & N.A. & N.A. & SLR & SLR & CRP & CRP & N.A. & N.A. & SLR & SLR & CRP & CRP \\
\hline & & SS Fault & N.A. & N.A. & N.A. & N.A. & CRP & CRP & N.A. & N.A. & N.A. & N.A. & CRP & CRP \\
\hline
\end{tabular}

Note:

IRI = International Roughness Index, $\mathrm{SN}_{40}=$ Skid Number at $40 \mathrm{mph}$

LS = Low Severity, MS = Medium Severity, HS = High Severity

N.A. refers to infeasible combination of pavement conditions

DN = Do Nothing, CRX = Crack Seal, GRD $=$ Diamond Grinding and Grooving, LTR $=$ Joint Bump Repair and Load Transfer Retrofitting, PFD $=$ Partial or Full Depth Repair, SOL $=$ Structural Overlay, SLR $=$ Slab Reduction Techniques, CRP $=$ Concrete Pavement Replacement

Only the best treatment is shown in this table. A combination of treatments can be used in addition to the one shown in the table.

Table 4.8: Comparing Intervention Levels from Historical Decision and Expert Opinions

(a) Asphalt Pavements

\begin{tabular}{|l|l|c|c|c|c|c|c|}
\hline Highway & Pavement & \multicolumn{6}{|c|}{ Intervention Level } \\
\cline { 3 - 8 } & $\begin{array}{l}\text { Preservation } \\
\text { Treatment }\end{array}$ & \multicolumn{3}{|c|}{ Historical Practices } & \multicolumn{3}{c|}{ Expert Opinion } \\
\cline { 3 - 8 } & & $\begin{array}{c}\text { IRI } \\
\text { (inch/mile) }\end{array}$ & $\begin{array}{c}\text { Crack } \\
\text { Severity }\end{array}$ & $\begin{array}{c}\text { Rut Depth } \\
\text { (inch) }\end{array}$ & $\begin{array}{c}\text { IRI } \\
\text { (inch/mile) }\end{array}$ & $\begin{array}{c}\text { Crack } \\
\text { Severity }\end{array}$ & $\begin{array}{c}\text { Rut Depth } \\
\text { (inch) }\end{array}$ \\
\hline \multirow{2}{*}{ Interstates } & Crack Seal & $<80$ & $\leq 2$ & $<0.25$ & $<150$ & $\leq 2$ & $<0.10$ \\
\cline { 3 - 8 } & Thin Overlay & $<150$ & $\leq 2$ & $<0.25$ & $<150$ & $\leq 2$ & $<0.25$ \\
\hline $\begin{array}{l}\text { Non- } \\
\text { Interstates }\end{array}$ & Crack Seal & $<80$ & $\leq 2$ & $<0.25$ & $<150$ & $\leq 2$ & $<0.10$ \\
\cline { 2 - 8 } & Thin Overlay & $<150$ & $\leq 2$ & $<0.25$ & $<150$ & $\leq 2$ & $<0.25$ \\
\hline
\end{tabular}

(b) Concrete Pavement (Jointed or Jointed Reinforced)

\begin{tabular}{|c|c|c|c|c|c|c|c|}
\hline \multirow{3}{*}{$\begin{array}{l}\text { Highway } \\
\text { Type }\end{array}$} & \multirow{3}{*}{$\begin{array}{l}\text { Pavement } \\
\text { Preservation } \\
\text { Treatment }\end{array}$} & \multicolumn{6}{|c|}{ Intervention Level } \\
\hline & & \multicolumn{3}{|c|}{ Historical Practices } & \multicolumn{3}{|c|}{ Expert Opinion } \\
\hline & & $\begin{array}{c}\text { IRI } \\
\text { (inch } / \text { mile) }\end{array}$ & $\begin{array}{c}\text { Crack } \\
\text { Severity }\end{array}$ & $\begin{array}{l}\text { Fault Depth } \\
\text { (inch) }\end{array}$ & $\begin{array}{c}\text { IRI } \\
\text { (inch/mile) }\end{array}$ & $\begin{array}{c}\text { Crack } \\
\text { Severity }\end{array}$ & $\begin{array}{l}\text { Fault Depth } \\
\text { (inch) }\end{array}$ \\
\hline \multirow{2}{*}{ Interstates } & Crack Seal & $<115$ & $<2$ & $<0.25$ & $<150$ & $\leq 1$ & $<0.10$ \\
\hline & $\begin{array}{l}\text { Partial and Full } \\
\text { Depth Repair }\end{array}$ & $<150$ & $<2$ & $<0.25$ & $<150$ & $\leq 2$ & $<0.25$ \\
\hline \multirow{2}{*}{$\begin{array}{l}\text { Non- } \\
\text { Interstates }\end{array}$} & Crack Seal & $<115$ & $<2$ & $<0.25$ & $<150$ & $\leq 1$ & $<0.10$ \\
\hline & $\begin{array}{l}\text { Partial and Full } \\
\text { Depth Repair }\end{array}$ & $<150$ & $<2$ & $<0.25$ & $<150$ & $\leq 2$ & $<0.25$ \\
\hline
\end{tabular}




\subsection{Applicability of Procedures to Incorporate Pavement Preservation Considerations in PMS}

The findings made in the paper allow the selection of pavement preservation treatments at project and network level. At the project level, treatment recommendations shown in Table 4.8 can be made on individual projects or highway segments for routine or corrective maintenance actions. At the network level, the recommendations found in the paper (Tables 4.3 to 4.7) can also be used to trigger decisions for consideration prior to optimization. However, some of the advantages and drawbacks associated with both methods must be recognized if agencies desire to develop their own intervention levels for their pavement management systems.

Table 4.9: Guidelines for Pavement Preservation Treatment Selection

\begin{tabular}{|c|c|c|c|c|c|c|c|c|c|}
\hline \multirow{3}{*}{$\begin{array}{l}\text { Pavement } \\
\text { Conditions }\end{array}$} & \multirow[t]{3}{*}{ Parameters } & \multicolumn{8}{|c|}{ Pavement Preservation Treatment } \\
\hline & & \multicolumn{4}{|c|}{ Asphalt } & \multicolumn{4}{|c|}{ Concrete (Jointed or Jointed Reinforced) } \\
\hline & & $\begin{array}{c}\text { Crack } \\
\text { Seal }\end{array}$ & $\begin{array}{c}\text { Micro- } \\
\text { surfacing }\end{array}$ & $\begin{array}{l}\text { Chip } \\
\text { Seal }\end{array}$ & $\begin{array}{c}\text { Thin } \\
\text { Overlay }\end{array}$ & $\begin{array}{c}\text { Crack } \\
\text { Seal }\end{array}$ & $\begin{array}{c}\text { Joint-Bump Repair } \\
\text { \& Load Transfer } \\
\text { Retrofitting }\end{array}$ & $\begin{array}{c}\text { Diamond } \\
\text { Grooving \& } \\
\text { Grinding }\end{array}$ & $\begin{array}{c}\text { Partial or } \\
\text { Full } \\
\text { Depth } \\
\text { Repair }\end{array}$ \\
\hline \multirow{2}{*}{$\begin{array}{l}\text { Functional } \\
\text { Class }\end{array}$} & Interstate & $\bullet$ & $\bullet$ & $x$ & $\bullet$ & $\bullet$ & $\bullet$ & $\bullet$ & $\bullet$ \\
\hline & $\begin{array}{l}\text { Non- } \\
\text { Interstate }\end{array}$ & $\bullet$ & $\bullet$ & $\bullet$ & $\bullet$ & $\bullet$ & $\bullet$ & $\bullet$ & $\bullet$ \\
\hline \multirow{3}{*}{$\begin{array}{l}\text { Roughness } \\
\text { (IRI) }\end{array}$} & Excellent & $\bullet$ & $\bullet$ & $\bullet$ & $\bullet$ & $\bullet$ & $\bullet$ & $\bullet$ & $\bullet$ \\
\hline & Fair & • & $\bullet$ & • & $\bullet$ & $\bullet$ & • & • & $\bullet$ \\
\hline & Poor & $x$ & $x$ & $x$ & $x$ & $x$ & $x$ & $x$ & $x$ \\
\hline \multirow{3}{*}{$\begin{array}{l}\text { Crack } \\
\text { Severity }\end{array}$} & Low & $\bullet$ & $\bullet$ & $\bullet$ & $\bullet$ & $\bullet$ & $\bullet$ & $\bullet$ & $\bullet$ \\
\hline & Medium & $\bullet$ & $\bullet$ & $\bullet$ & • & $\bullet$ & $\bullet$ & • & $\bullet$ \\
\hline & High & $?$ & $x$ & $x$ & $?$ & ? & $x$ & $x$ & $?$ \\
\hline \multirow{3}{*}{$\begin{array}{l}\text { Rutting } \\
\text { (Asphalt) }\end{array}$} & Low & $\bullet$ & $\bullet$ & $\bullet$ & $\bullet$ & N.A. & N.A. & N.A. & N.A. \\
\hline & Medium & $?$ & • & $?$ & $\bullet$ & N.A. & N.A. & N.A. & N.A. \\
\hline & High & $x$ & $?$ & $x$ & $x$ & N.A. & N.A. & N.A. & N.A. \\
\hline \multirow{3}{*}{$\begin{array}{l}\text { Faulting } \\
\text { (PCC) }\end{array}$} & Low & N.A. & N.A. & N.A. & N.A. & - & - & - & - \\
\hline & Medium & N.A. & N.A. & N.A. & N.A. & $?$ & - & - & - \\
\hline & High & N.A. & N.A. & N.A. & N.A. & $x$ & $?$ & $x$ & $x$ \\
\hline \multirow[t]{2}{*}{ Friction } & Good & $\bullet$ & $\bullet$ & $\bullet$ & • & • & - & - & $\bullet$ \\
\hline & Poor & $x$ & $\bullet$ & • & • & $x$ & $x$ & • & • \\
\hline
\end{tabular}

Notes:

- Recommended

? May be recommended

$\mathbf{x}$ Not recommended

N.A. refers to treatment is not applicable.

Table 4.9 summarizes the advantages and drawbacks of both procedures. An advantage of using historical information lies in their economy: there is no need to carry out separate desk or field monitoring of each indicator of pavement distress. However, the reliance on historical information assumes implicitly 
that past decisions are rational and consistent, which may or may not be true for every state highway agency. It also ignores factors such as availability of funding and other policy constraints. This poses a challenge to agencies if the intervention levels were to be successfully implemented to incorporate preservation treatments in pavement management.

Decision matrices typically reflect the decision processes used by the agency. In the paper, it is found to be generally consistent with documented guidelines in the literature (Shuler, 1984; Hicks et al., 1997, 2000; INDOT, 2002; Zimmerman and Peskin, 2004; Smith et al., 2008; Wu et al., 2009) and the experiences of pavement managers at districts and sub-districts. The advantages of decision trees include the flexibility to modify the decision criteria (treatment types and timings), the capability to generate consistent recommendations, and the relative ease with which the selection process can be explained and programmed. Hicks et al. (1997) stated that decision trees can be used effectively in the selection/identification of suitable preventive maintenance treatments as well as routine preservation and rehabilitation options.

In light of the advantages and drawbacks associated with both procedures, it is believed that decision matrices using expert opinions are considered superior to the historical information-based intervention level for pavement management purposes. As new and innovative pavement preservation techniques become available, there is always a need to continuously refine and update the treatment intervention levels within the pavement management system. The expert opinion procedure is much better-suited than historical practice-based procedure for this purpose since there are insufficient data available to perform any historical data-based analysis. Coupled with regular field monitoring of pavement conditions and appropriate distress performance modeling, the decision matrices can allow the selection of appropriate treatments within the pavement management system at both project and network levels.

\subsection{Chapter Summary}

This chapter has demonstrated two different procedures to develop intervention levels for pavement preservation treatments. The first procedure involves using historical decisions made by an agency to determine treatment intervention levels, while the second procedure seeks expert opinions to develop relevant treatment decision matrices. Using Indiana's data, both procedures appear to be reasonable. The results of the two procedures are consistent with commonly-used values in the literature. However, the procedure using distress-based decision matrices is more desirable because it can be easily adopted for new and innovative pavement materials and treatments. 


\title{
CHAPTER 5: SHORT AND LONG TERM EFFECTIVENESS OF PAVEMENT PRESERVATION TREATMENTS
}

\author{
$\underline{5.1 \quad \text { Introduction }}$
}

Another important aspect of a pavement preservation program is the development of performance models for pavement preservation treatments. These performance models are required for (i) comparing two or more pavement strategies at the project level and selecting the best strategy; and (ii) selection of projects within a network level pavement preservation framework. In this chapter, performance models are developed for selected preservation treatments on asphalt and concrete pavements. The use of remaining service life in evaluating pavement strategies is then illustrated. This serves as a preamble for the development of a remaining service life based pavement preservation treatment selection framework for the districts.

\subsection{Long Term Pavement Performance for Existing Pavements}

Long term pavement performance models are developed for existing asphalt and concrete pavements. This is required to allow a "base case" analysis of the "do-nothing" strategy in project and network levels strategy selection. In this study, the regression approach is adopted to develop performance models for existing pavements. This approach has been adopted by many researchers and has been the main form of pavement performance models used in the Indiana pavement management system (Labi and Sinha, 2003; Lamptey et al., 2004). In most cases, models were developed for functional performance indicators such as pavement roughness (in terms of international roughness index IRI), rutting on asphalt pavements (in terms of rut depth), faulting on PCC pavements (in terms of fault depth) and surface distress indicator (in terms of pavement condition rating PCR). For example, Lamptey et al. (2004) had developed various pavement performance models for different pavement treatments for Indiana pavements using multiple linear regression. These models were developed for use in a life-cycle cost analysis framework.

In this study, long term pavement performance models are developed in the following functional form: 
$y_{i}=\exp \left(\beta_{0}+\sum_{i=1}^{n} \beta_{i} x_{i}\right)$

where $y_{i}$ is the performance measure of interest, $x_{i}$ is the independent variable and $\beta_{0}$ and $\beta_{i}$ are the regression coefficients. Using pavement performance data from the Indiana pavement management databases, models are developed for interstates/national highway system (NHS) asphalt pavements in Indiana for three different functional performance measures (IRI, PCR and rut depth):

$$
\begin{aligned}
& I R I=\exp 4.023+0.0040 A A D T T \times t+0.0025 A N D X \times t \\
& P C R=\exp 4.572-0.0012 A A D T T \times t-0.0023 A N D X \times t \\
& R u t=\exp -3.760+0.0095 A A D T T \times t+0.0068 A N D X \times t
\end{aligned}
$$

where AADT is the average annual daily truck traffic, $t$ is the time in years and ANDX is the average annual freezing index evaluated for the freezing season. Appendix II describes the computation of freezing index in greater detail. For a pavement in the Indianapolis region (ANDX $=600^{\circ} \mathrm{F}$-day) with a relatively heavy truck traffic of 34,000 trucks per day, the average service life of asphalt pavements is found to be approximately 20 years. For a lower truck traffic of say, 12,000 trucks per day, the average service life of asphalt pavements increases to about 23 years. This finding is consistent with the design values used in the Indiana Pavement Design Guide (INDOT, 2009) where asphalt pavements are assumed to have service lives between 20 and 25 years.

Similar models can be derived for interstates/national highway system (NHS) PCC pavements for IRI, PCR and faulting:

$$
\begin{aligned}
& I R I=\exp 4.259+0.0024 A A D T T \times t+0.0015 A N D X \times t \\
& P C R=\exp 4.582-0.0010 A A D T T \times t-0.0013 A N D X \times t \\
& \text { Fault }=\exp -4.960+0.0105 A A D T T \times t+0.0108 A N D X \times t
\end{aligned}
$$

where AADT is the average annual daily truck traffic, $t$ is the time in years and ANDX is the average annual freezing index evaluated for the freezing season. For a pavement in the Indianapolis region (ANDX $=600^{\circ} \mathrm{F}$-day) with a relatively heavy truck traffic of 34,000 trucks per day, the average service life of PCC pavements is found to be approximately 25 years. For a lower truck traffic of say, 12,000 trucks per day, the average service life of PCC pavements increases to about 28 years. This finding is consistent with the design values used in the Indiana Pavement Design Guide (INDOT, 2009) where PCC pavements are assumed to have service lives between 25 and 30 years.

Pavement performance models are also be developed for both asphalt and PCC non-NHS pavements using the following regression equation: 
$y_{i}=\exp \beta_{0}+\beta_{1} \times A A D T T \times t+\beta_{2} \times A N D X \times t$

where $y_{i}$ is the performance measure (IRI, PCR, rut depth for asphalt pavements and fault depth for PCC pavements), AADT is the average annual daily truck traffic, $t$ is the time in years, ANDX is the average annual freezing index evaluated for the freezing season and $\beta_{0}, \beta_{1}$ and $\beta_{2}$ are the regression coefficients. Table 5.1 shows the performance models for existing asphalt and PCC pavements for both interstates/NHS and non-NHS.

Table 5.1: Regression Coefficients for Performance Models of Existing Pavements

\begin{tabular}{|c|c|c|c|c|c|}
\hline Pavement Type & $\begin{array}{l}\text { Functional } \\
\text { Class }\end{array}$ & $\begin{array}{l}\text { Performance } \\
\text { Measure }\end{array}$ & $\beta_{0}$ & $\beta_{1}$ & $\beta_{2}$ \\
\hline \multirow[t]{6}{*}{ Asphalt } & \multirow[t]{3}{*}{ Interstate/NHS } & IRI (in/mile) & 4.023 & 0.0120 & 0.0025 \\
\hline & & PCR & 4.572 & -0.0044 & -0.0073 \\
\hline & & Rut Depth (in) & -3.760 & 0.0095 & 0.0068 \\
\hline & \multirow[t]{3}{*}{ Non-NHS } & IRI (in/mile) & 4.123 & 0.0139 & 0.0043 \\
\hline & & PCR & 4.572 & -0.0051 & -0.0066 \\
\hline & & Rut Depth (in) & -3.760 & 0.0125 & 0.0108 \\
\hline \multirow[t]{6}{*}{ PCC } & \multirow[t]{3}{*}{ Interstate/NHS } & IRI (in/mile) & 4.259 & 0.0094 & 0.0015 \\
\hline & & PCR & 4.582 & -0.0030 & 0.0053 \\
\hline & & Fault Depth (in) & -4.960 & 0.0105 & 0.0108 \\
\hline & \multirow[t]{3}{*}{ Non-NHS } & IRI (in/mile) & 4.364 & 0.0109 & 0.0035 \\
\hline & & PCR & 4.567 & -0.0056 & -0.0064 \\
\hline & & Fault Depth (in) & -4.680 & 0.0285 & 0.0308 \\
\hline
\end{tabular}

\subsection{Performance Models for Pavement Preservation Treatments}

Short term and long term effectiveness models are developed for asphalt and PCC preservation treatments. In this study, the following preservation treatments are explored: crack seal, patching, microsurfacing and thin preventive maintenance overlay for asphalt pavements; crack seal, partial depth patching and full depth patching on PCC pavements. The developed models could be used for either strategy comparison at the project level or could be input into the network-level pavement management system for network level project selection.

\subsubsection{Short Term Effectiveness of Pavement Preservation Treatments}

The concepts of performance jump and deterioration rate reduction are applied to determine the short term effectiveness of preservation treatments on asphalt and PCC pavements. For a given performance measure $y$ (see Figure 5.1), the performance jump is simply defined as: 
Performance Jump PJ $=\mathrm{y}_{\mathrm{b}}-\mathrm{y}_{\mathrm{a}}$

where $\mathrm{y}_{\mathrm{b}}$ is the condition before treatment and $\mathrm{y}_{\mathrm{a}}$ is the condition after treatment.

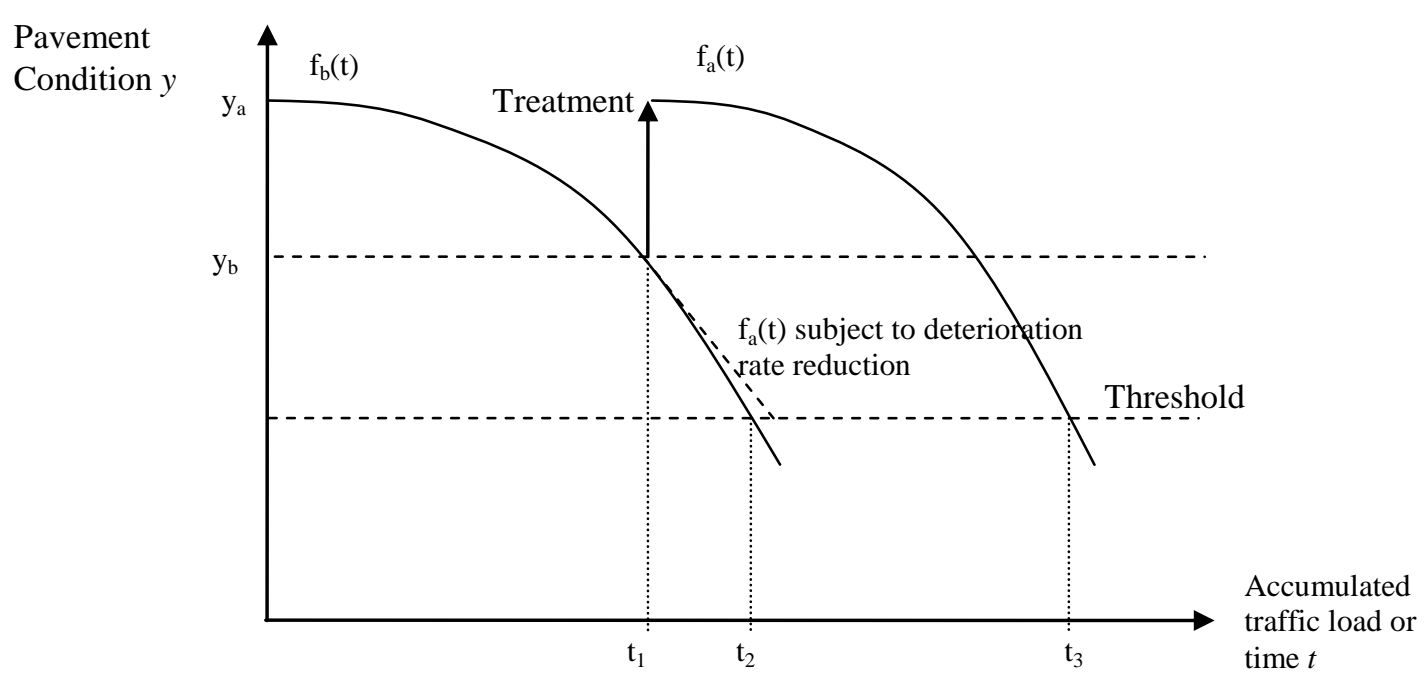

Figure 5.1: Illustration of performance jump and deterioration rate reduction

In some cases, there might not be a discernable performance jump associated with the treatment but a reduction in the deterioration rate is experienced. In this case, it is more appropriate to use the term "deterioration rate reduction" (DRR) as a measure of the effectiveness of the preservation treatment. DRR can be defined as:

DRR = deterioration rate before treatment - deterioration rate after treatment

$$
=\mathrm{f}^{\prime}{ }_{b}(\mathrm{t})-\mathrm{f}^{\prime}{ }_{\mathrm{a}}(\mathrm{t})
$$

where $f_{b}(t)$ is the deterioration rate before the treatment and is the $f^{\prime}{ }_{a}(t)$ is the deterioration rate after the treatment. $\mathrm{f}_{\mathrm{b}}(\mathrm{t})$ can be estimated from the Indiana pavement management system using the following equation:

$\mathrm{f}^{\prime}{ }_{\mathrm{b}}(\mathrm{t})=[$ Condition at year $(\mathrm{t}-2)]-[$ Condition at year $(\mathrm{t}-1)] /$ time interval between data collection

$$
=\mathrm{y}_{\mathrm{t}-2}-\mathrm{y}_{\mathrm{t}-1}
$$

where $\mathrm{y}_{\mathrm{t}-2}$ is the pavement condition at year $(\mathrm{t}-2)$ and $\mathrm{y}_{\mathrm{t}-1}$ is the pavement condition at year $(\mathrm{t}-1)$.

An illustration is provided in Figure 5.2 to highlight the practical significance of the above equation. It can be seen from the figure that $\mathrm{f}^{\prime}(\mathrm{t})$ can be estimated using condition data of the two consecutive years prior to the application of the treatment. This provides managers with a convenient method to evaluate deterioration rate and implement the concept of deterioration rate reduction in a pavement management system. 


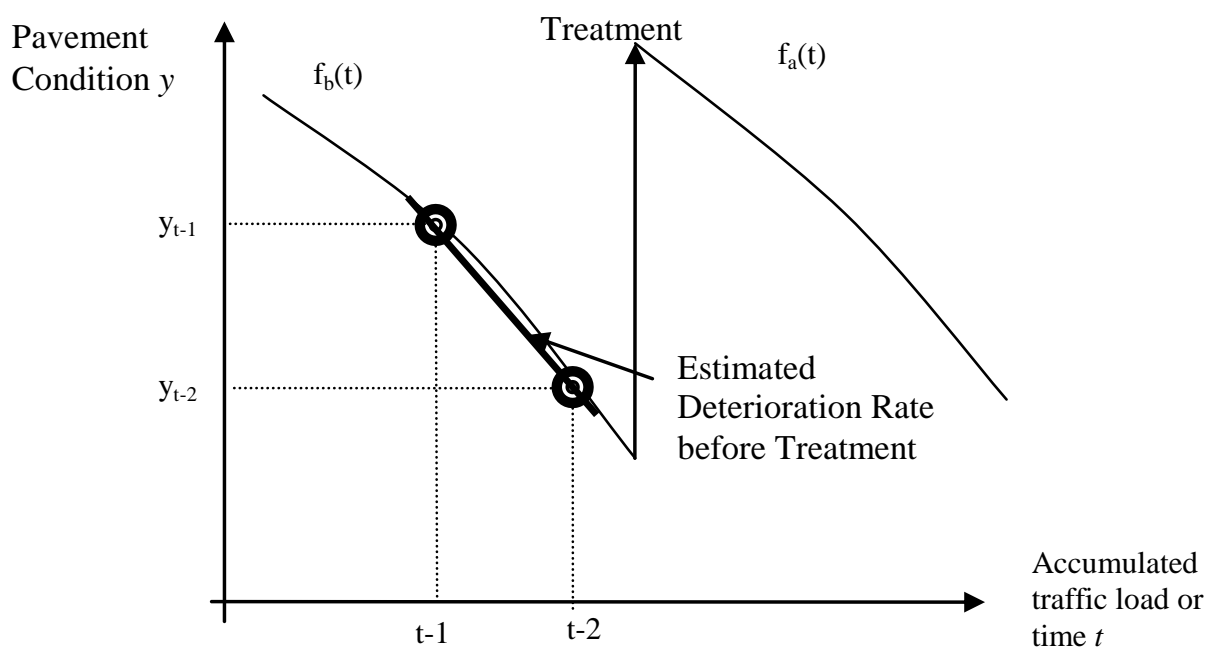

Figure 5.2: Computation of deterioration rate before treatment

Using the pavement condition data, traffic data and contracts/work information from the Indiana pavement management system, performance jump models can be developed for the different asphalt and PCC preservation treatments. Table 5.2 shows the short term effectiveness models for thin PM overlay, microsurfacing, crack seal and patching on asphalt pavements for three different functional performance measures: IRI, PCR and rut depth. It is noted that for crack seal and patching, there is no significant improvement in IRI due to these treatments. However, a deterioration rate reduction is detected, as shown in Table 5.2.

Table 5.2: Short Term Effectiveness Models for Asphalt Preservation Treatments

\begin{tabular}{|c|c|}
\hline Treatment & Short Term Effectiveness Models \\
\hline $\begin{array}{l}\text { Thin Preventive } \\
\text { Maintenance Overlay }\end{array}$ & $\begin{array}{l}\mathrm{PJ}_{\mathrm{IRI}}=\exp \left(-1.5748 \times 10^{-8} \mathrm{IRI}_{\mathrm{b}}{ }^{2}-0.01097 \mathrm{IRI}_{\mathrm{b}}+4.7087\right) \\
\text { Fully restores PCR to } 100 \\
\text { Fully restores rut depth to zero }\end{array}$ \\
\hline Microsurfacing & $\begin{array}{l}\mathrm{PJ}_{\mathrm{IRI}}=11.4995+\exp \left(0.01874 \mathrm{IRI}_{\mathrm{b}}\right) \\
\mathrm{PJ}_{\mathrm{PCR}}=20.07-0.198 \mathrm{PCR}_{\mathrm{b}} \\
\mathrm{PJ}_{\text {Rut }}=0.03002+2.4805 \mathrm{Rut}_{\mathrm{b}}{ }^{2}\end{array}$ \\
\hline Crack Seal & $\begin{array}{l}\mathrm{DRR}_{\mathrm{IRI}}=\left(1-3.7600 \times 10^{-4} \mathrm{IRI}_{\mathrm{b}}\right) * \mathrm{f}^{\prime}{ }_{\mathrm{b}}(\mathrm{t}) \\
\mathrm{PJ}_{\mathrm{PCR}}=19.73-0.213 \mathrm{PCR}_{\mathrm{b}} \\
\text { No effect on rut depth }\end{array}$ \\
\hline Patching & $\begin{array}{l}D_{R R} R_{I R I}=\left(1-3.5712 \times 10^{-4} I R I_{b}\right) * f^{\prime}(t) \\
\text { Fully restores PCR to } 100 \\
\text { No effect on rut depth }\end{array}$ \\
\hline
\end{tabular}

Table 5.3 shows the short term effectiveness models for crack seal, partial depth patching and full depth patching on PCC pavements for IRI, PCR and fault depth. It is observed that crack seal reduces 
deterioration rate of IRI on PCC pavements, produces a performance jump in terms of PCR and has no effect of faulting. Performance jumps are observed in terms of PCR and IRI for partial depth and full depth patching and faulting is fully restored.

Table 5.3: Short Term Effectiveness Models for PCC Preservation Treatments

\begin{tabular}{|l|l|}
\hline Treatment & Short Term Effectiveness Models \\
\hline Crack Seal & DRR $_{\text {IRI }}=\left(1-3.5200 \times 10^{-4} \mathrm{IRI}_{\mathrm{b}}\right) \times \mathrm{f}^{\prime}{ }_{\mathrm{b}}(\mathrm{t})$ \\
& $\mathrm{PJ}_{\mathrm{PCR}}=0.9418 * \exp \left(0.0086 \mathrm{PCR}_{\mathrm{b}}\right)$ \\
& No effect on fault depth \\
\hline Partial Depth Patching & $\mathrm{PJ}_{\mathrm{IRI}}=2.9428 * \exp \left(0.0124 \mathrm{IRI}_{\mathrm{b}}\right)$ \\
& $\mathrm{PJ}_{\mathrm{PCR}}=0.97528 * \exp \left(0.0118 \mathrm{PCR}_{\mathrm{b}}\right)$ \\
& Fully restores fault depth to zero \\
\hline Full Depth Patching & $\mathrm{PJ}_{\mathrm{IRI}}=3.0547 * \exp \left(0.0155 \mathrm{IRI}_{\mathrm{b}}\right)$ \\
& $\mathrm{PJ}_{\mathrm{PCR}}=0.9917 * \exp \left(0.0120 \mathrm{PCR}_{\mathrm{b}}\right)$ \\
& Fully restores fault depth to zero \\
\hline
\end{tabular}

\subsubsection{Long Term Effectiveness of Pavement Preservation Treatments}

Besides the short term effectiveness of pavement preservation treatments as presented in the previous section, certain preservation treatments such as thin PM overlays and microsurfacing are known to produce deterioration curves significantly different from that exhibited by the existing pavements (references). As such, there is a need to develop new deterioration models for thin PM overlays and microsurfacing for pavements in Indiana.

Using the pavement condition data from the pavement management databases, traffic data and work/contract information, long term performance models for thin PM overlays and microsurfacing on Indiana pavements were developed. Table 5.4 shows the performance models for these two preservation treatments in the form of the following equation:

$$
y_{i}=\exp \beta_{0}+\beta_{1} \times A A D T T \times t+\beta_{2} \times A N D X \times t
$$

where $y_{\mathrm{i}}$ is the performance measure (IRI, PCR, rut depth for asphalt pavements and fault depth for PCC pavements), AADT is the average annual daily truck traffic, $t$ is the time in years, ANDX is the average annual freezing index evaluated for the freezing season and $\beta_{0}, \beta_{1}$ and $\beta_{2}$ are the regression coefficients. Using an IRI threshold of $125 \mathrm{inch} / \mathrm{mile}$, the use of thin PM overlays is found to yield an average service life of 9 years for a heavy truck traffic volume of 34,000 trucks per day and 14 years for a relatively low truck traffic volume of 12,000 trucks per day. The expected service lives are similar to that stated in the Indiana Design Manual guidelines (INDOT, 2009). 
Table 5.4: Long Term Performance Models for Preservation Treatments on Asphalt Pavements

\begin{tabular}{|c|c|c|c|c|c|}
\hline Treatment & $\begin{array}{c}\text { Functional } \\
\text { Class }\end{array}$ & $\begin{array}{c}\text { Performance } \\
\text { Measure }\end{array}$ & $\beta_{0}$ & $\beta_{1}$ & $\beta_{2}$ \\
\hline \multirow{3}{*}{$\begin{array}{c}\text { Thin PM } \\
\text { Overlay }\end{array}$} & \multirow{2}{*}{ Interstate/NHS } & IRI (in/mile) & 4.174 & 0.0064 & 0.0038 \\
\cline { 3 - 5 } & & PCR & 4.571 & -0.0075 & -0.0048 \\
\cline { 3 - 5 } & \multirow{3}{*}{ Non-NHS } & Rut Depth (in) & -3.760 & 0.0506 & 0.1730 \\
\cline { 3 - 6 } & & IRI (in/mile) & 4.223 & 0.0094 & 0.0072 \\
\cline { 3 - 5 } & & PCR & 4.571 & -0.0091 & -0.0069 \\
\cline { 3 - 5 } & \multirow{2}{*}{ All } & Rut Depth (in) & -3.760 & 0.0604 & 0.1950 \\
\hline \multirow{3}{*}{ Microsurfacing } & IRI (in/mile) & 4.140 & 0.0045 & 0.0018 \\
\cline { 3 - 5 } & & PCR & 4.578 & -0.0030 & -0.0058 \\
\cline { 3 - 5 } & & Rut Depth (in) & -3.760 & 0.0169 & 0.0457 \\
\hline
\end{tabular}

\subsection{Remaining Service Life Approach for Pavement Preservation}

With the pavement performance models and the triggers determined, it is now possible to evaluate pavement preservation strategies using the remaining service life approach. This approach has been purported by Galehouse (2009) and other researchers as a viable alternative to quantify pavement preservation treatment performance. In this section, a strategy evaluation approach using pavement remaining service life is proposed.

\subsubsection{Computation of Remaining Service Life}

Remaining service life is defined as the time for the pavement to reach its service threshold or trigger. Figure 5.3 illustrates how the remaining service life can be computed. Point A in Figure 5.3 represents the current condition of the pavement $y_{1}$ at time $t_{1}$. Point $B$ represents the point where the pavement reaches its service threshold $\mathrm{y}_{\text {threshold }}$ at time $\mathrm{t}_{2}$. For a preservation treatment performed at point $\mathrm{A}$, there could be a performance jump, resulting in the service life to increase. The new end-of-service-life of the pavement is represented by Point $\mathrm{C}$ at time $\mathrm{t}_{3}$. From the figure, the following definitions can be obtained:

Remaining service life before treatment $=t_{2}-t_{1}$

Remaining service life after treatment $=\mathrm{t}_{4}-\mathrm{t}_{1}$

Remaining service life extension $=\mathrm{t}_{4}-\mathrm{t}_{2}$

Treatment life $=\mathrm{t}_{3}-\mathrm{t}_{1}$

It can be observed from the figure that the remaining service life is closely related to the pavement performance models. In general, if the functional form of the performance model is given by Equation (5.8), the remaining service life is in the form: 
$t=\frac{\ln y_{\text {threshold }}-\ln y_{i}}{\beta_{1} \times A A D T T+\beta_{2} \times A N D X}$

where $\mathrm{y}_{\mathrm{i}}$ is the performance measure (IRI, PCR, rut depth for asphalt pavements and fault depth for PCC pavements), $\mathrm{y}_{\text {threhsold }}$ is the threshold value for the performance measure, AADT is the average annual daily truck traffic, $\mathrm{t}$ is the time in years, ANDX is the average annual freezing index evaluated for the freezing season, and $\beta_{1}$ and $\beta_{2}$ are the regression coefficients. Remaining service lives for existing pavements and for various asphalt or PCC treatments can be determined using the coefficient values stated in Tables 5.1 and 5.4 respectively.

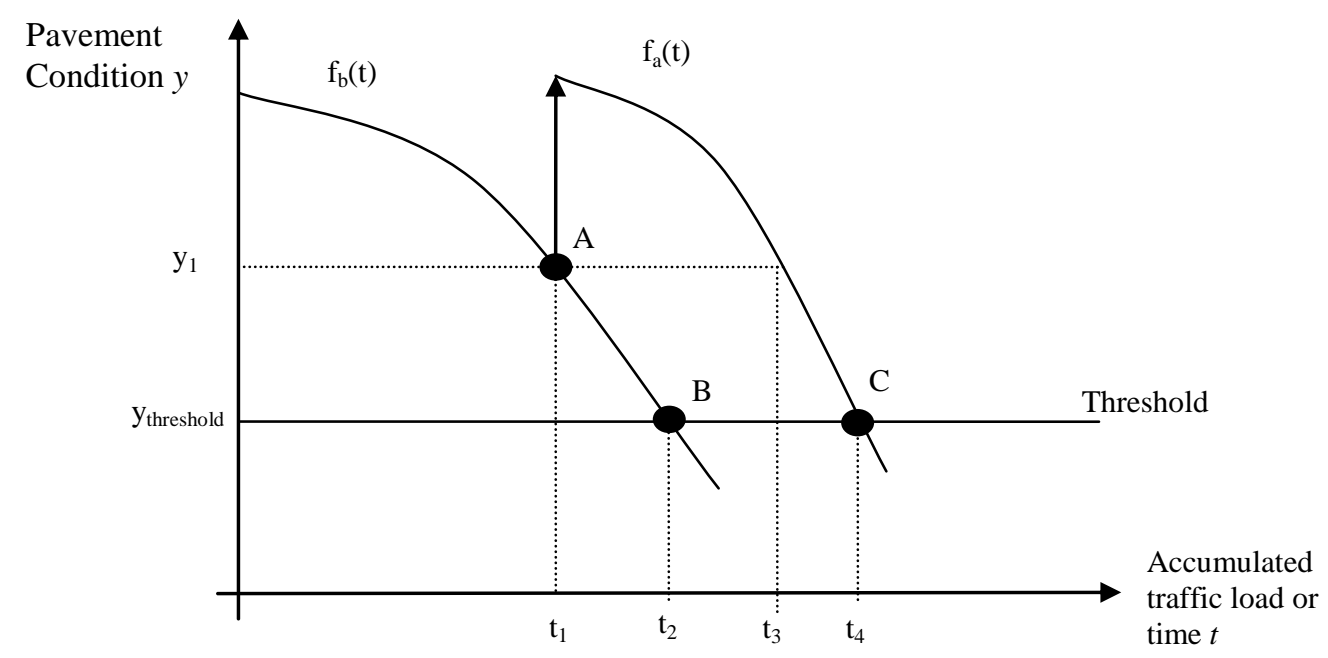

Figure 5.3: Computation of remaining service life

\subsubsection{Use of Remaining Service Life in Pavement Strategy Comparison}

In this section, the remaining service life approach is applied to compare different strategies. The approach for evaluating competing strategies is described in Figure 5.4. Each step in the analysis procedure can be described as follow:

\section{Step 0: Establish the Base Case}

The base scenario is simply the "do-nothing" case. In this case, it is assumed that no treatment is performed and the pavement will deteriorate as described by Equation (5.4) and Table 5.1.

Step 1: Identify Alternatives

Alternative strategies (or treatments) are determined using the decision matrices developed in Chapter 4. The performance models (short and long term effectiveness models) are determined as described in the previous sections. 
Step 2: Determine Future Pavement Performance and Remaining Service Life

Future performance of the pavement for the base case and the alternatives can be predicted using the performance models developed earlier in the chapter. Remaining service life and remaining service life extension for each scenario can be determined using Equation (5.12) for given performance thresholds.

\section{Step 3: Determine the Cost of Preservation Treatment (Optional)}

The cost of each preservation treatment can be estimated using historical cost values (shown in Table 5.5). If actual cost information is available for a specific project, it should be used instead. This step is optional depending on the choice of project selection criteria (see Step 4).

Step 4: Comparison of Alternatives and Selection of Best Strategy

Each strategy can be compared based on (i) remaining service life, (ii) remaining service life extension, (iii) cost effectiveness (in terms of cost divided by remaining service life, or cost divided by remaining service life extension). For cost effectiveness, the cost of each alternative has to be determined (see Step 3 ). The alternative that gives the longest life or life extension or lowest cost per life span bought is considered to be the best alternative.

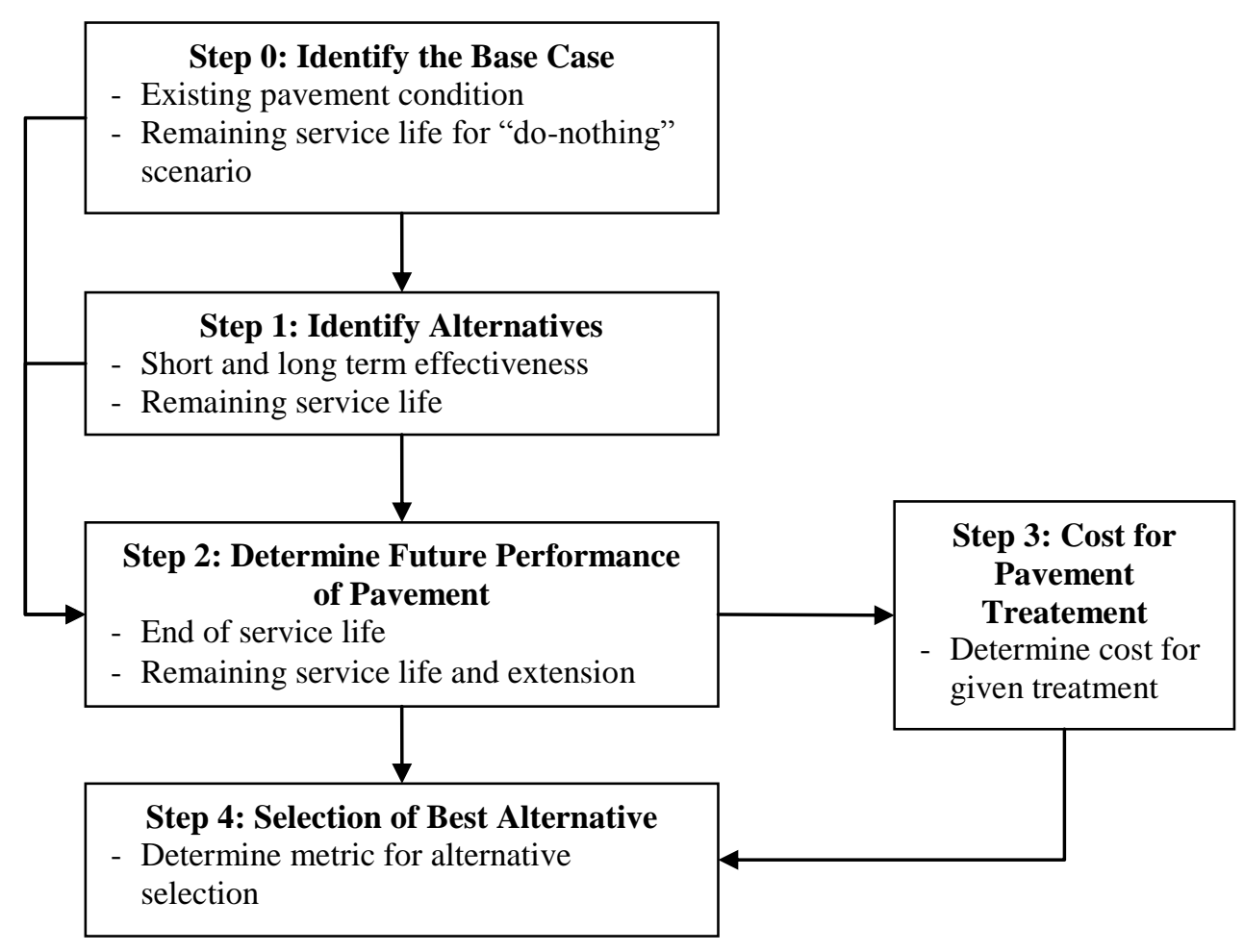

Figure 5.4: Remaining service life approach for strategy selection 
Table 5.5: Cost for Pavement Repair and Rehabilitation Treatments (Lamptey et al., 2004)

\begin{tabular}{|c|c|c|c|c|c|c|c|}
\hline \multirow{2}{*}{$\begin{array}{c}\text { Work } \\
\text { Category }\end{array}$} & \multirow{2}{*}{$\begin{array}{l}\text { Work } \\
\text { Type }\end{array}$} & \multirow[t]{2}{*}{ Work Designation } & & \multicolumn{4}{|c|}{ Cost per Lane Mile (\$) } \\
\hline & & & No. & Average & Minimum & Maximum & $\begin{array}{c}\text { Std } \\
\text { Deviation }\end{array}$ \\
\hline \multirow{8}{*}{$\begin{array}{l}\text { J100-199 } \\
\text { (Pavement } \\
\text { Repair or } \\
\text { Rehabilitation) }\end{array}$} & J000 & $\begin{array}{l}\text { Pavement Repair Or } \\
\text { Rehabilitation }\end{array}$ & 36 & 129,518 & 8,717 & $1,941,216$ & 318,480 \\
\hline & $\mathrm{J} 100$ & Patch And Rehab Pavement & 3 & 92,441 & 24,939 & 189,165 & 85,925 \\
\hline & J111 & $\begin{array}{l}\text { Full Depth Patching, } \\
\text { Bituminous }\end{array}$ & 1 & 37,519 & 37,519 & 37,519 & \\
\hline & J112 & $\begin{array}{l}\text { Full And Shallow Depth } \\
\text { Patching, Bit }\end{array}$ & 1 & 30,313 & 30,313 & 30,313 & \\
\hline & J120 & $\begin{array}{l}\text { Patch And Rehab Concrete } \\
\text { Pavement }\end{array}$ & 1 & 104,932 & 25,770 & 184,093 & 111,951 \\
\hline & J121 & $\begin{array}{l}\text { Full Depth Patching, } \\
\text { Concrete }\end{array}$ & 10 & 917,123 & 18,535 & $7,849,122$ & $2,441,822$ \\
\hline & J122 & $\begin{array}{l}\text { Full And Shallow Depth } \\
\text { Patching,Conc }\end{array}$ & 2 & 257,270 & 257,270 & 257,270 & \\
\hline & J124 & $\begin{array}{l}\text { Reseal Joints And Patch } \\
\text { Conc Pvmnt }\end{array}$ & 6 & 63,858 & 14,126 & 162,390 & 56,126 \\
\hline \multirow{13}{*}{$\begin{array}{l}\text { J200-299 } \\
\text { (Pavement } \\
\text { Resurfacing, } \\
\text { Non-3R/4R } \\
\text { Standards) }\end{array}$} & J200 & $\begin{array}{l}\text { Resurface (Non-3r/4r } \\
\text { Standards) }\end{array}$ & 1017 & 136,516 & 1,686 & $3,005,028$ & 248,973 \\
\hline & $\mathrm{J} 210$ & $\begin{array}{l}\text { Resurface Bit. Over Bit. } \\
\text { Pavement }\end{array}$ & 17 & 348,769 & 38,321 & $3,837,295$ & 909,219 \\
\hline & $\mathrm{J} 211$ & Bit Overlay, Thin Lay & 25 & 62,753 & 17,679 & 279,795 & 65,549 \\
\hline & $\mathrm{J} 212$ & $\begin{array}{l}\text { Bit Overlay, Multiple } \\
\text { Structural Lays }\end{array}$ & 90 & 207,088 & 16,632 & $1,035,173$ & 228,292 \\
\hline & $\mathrm{J} 213$ & $\begin{array}{l}\text { Mill Surface And Bit } \\
\text { Overlay }\end{array}$ & 99 & 96,925 & 2,421 & $1,753,357$ & 199,489 \\
\hline & $\mathrm{J} 214$ & $\begin{array}{l}\text { Mill Full Depth And Bit } \\
\text { Overlay }\end{array}$ & 6 & $1,400,508$ & 17,095 & $5,836,342$ & $2,220,115$ \\
\hline & $\mathrm{J} 215$ & $\begin{array}{l}\text { Microsurface } \\
\text { (Microtexture) }\end{array}$ & 6 & 23,320 & 11,018 & 67,939 & 21,971 \\
\hline & $\mathrm{J} 216$ & $\begin{array}{l}\text { Widen Pavement And Bit } \\
\text { Overlay }\end{array}$ & 2 & 213,677 & 95,459 & 328,896 & 162,943 \\
\hline & $\mathrm{J} 220$ & Resurface Concrete Pavement & 2 & 135,944 & 133,553 & 138,335 & 3,381 \\
\hline & $\mathrm{J} 221$ & $\begin{array}{l}\text { Crack And Seat \& Bit } \\
\text { Overlay }\end{array}$ & 4 & 90,380 & 1,963 & 187,458 & 100,420 \\
\hline & $\mathrm{J} 222$ & $\begin{array}{l}\text { Rubblize Existing Pvmt \& } \\
\text { Bit Overlay }\end{array}$ & 3 & 780,654 & 628,778 & 973,115 & 175,719 \\
\hline & $\mathrm{J} 223$ & $\begin{array}{l}\text { Concrete Overlay Existing } \\
\text { Conc Pvmt }\end{array}$ & 1 & 480,718 & 480,718 & 480,718 & \\
\hline & $\mathrm{J} 224$ & $\begin{array}{l}\text { Concrete Overlay Existing } \\
\text { Bit Pvmt }\end{array}$ & 9 & 40,447 & 13,218 & 73,316 & 22,924 \\
\hline
\end{tabular}

An illustration of the analysis procedure is provided in this section. In this case, it is sought to compare the effectiveness of three different asphalt preservation treatments: annual crack sealing, annual patching and thin PM overlay on an Interstate/NHS asphalt pavement. It is assumed that the average annual daily truck traffic on the pavement section is 23,000 trucks per day, average annual freeze index is $600^{\circ} \mathrm{F}$-day (typical of Indianapolis region), current IRI is 125 inches per mile and threshold IRI is 150 inches per mile. In this illustration, IRI is used as the sole treatment selection criteria. 
Figure 5.5 shows the performance of the pavement subject to the base case (i.e. do-nothing) and the three alternatives based on IRI. It can be seen from the figure that thin PM overlay would result in a discernable performance jump, whereas crack seal and patching results in deterioration rate reductions. In terms of remaining service life, the do-nothing approach yields a RSL of 14 years. The application of thin PM overlay results in a treatment life of 15 years (which is similar to that used in Chapter 52), a remaining service life of 20 years and an extension (compared to the base case) of 6 years. Routine crack sealing results in a treatment life of one year (similar to that used in Chapter 52), a remaining service life of 16 years and an extension (compared to the base case) of 2 years. Last, routine patching results in a treatment life of one year, a remaining service life of 17 years and an extension (compared to the base case) of 3 years. Cost effectiveness can be compared along with the other selection metrics, as shown in Table 5.6. It can be seen from the table that in terms of life span, thin PM overlay gives the best performance in terms of RSL and RSLE, whereas routine crack seal provides the best value for money in terms of cost per unit year of life extension. However, a critical component of the latter treatment is that there needs to be a formal policy for routine crack seal on the pavements annually. A comparison can be made against structural HMA overlays (see Table 5.6). It can be clearly seen that preservation treatments is much more cost effective in treating pavements without structural failure as compared to the traditional rehabilitation treatment. This highlights the importance of pavement preservation in maintaining the conditions of our highway assets.

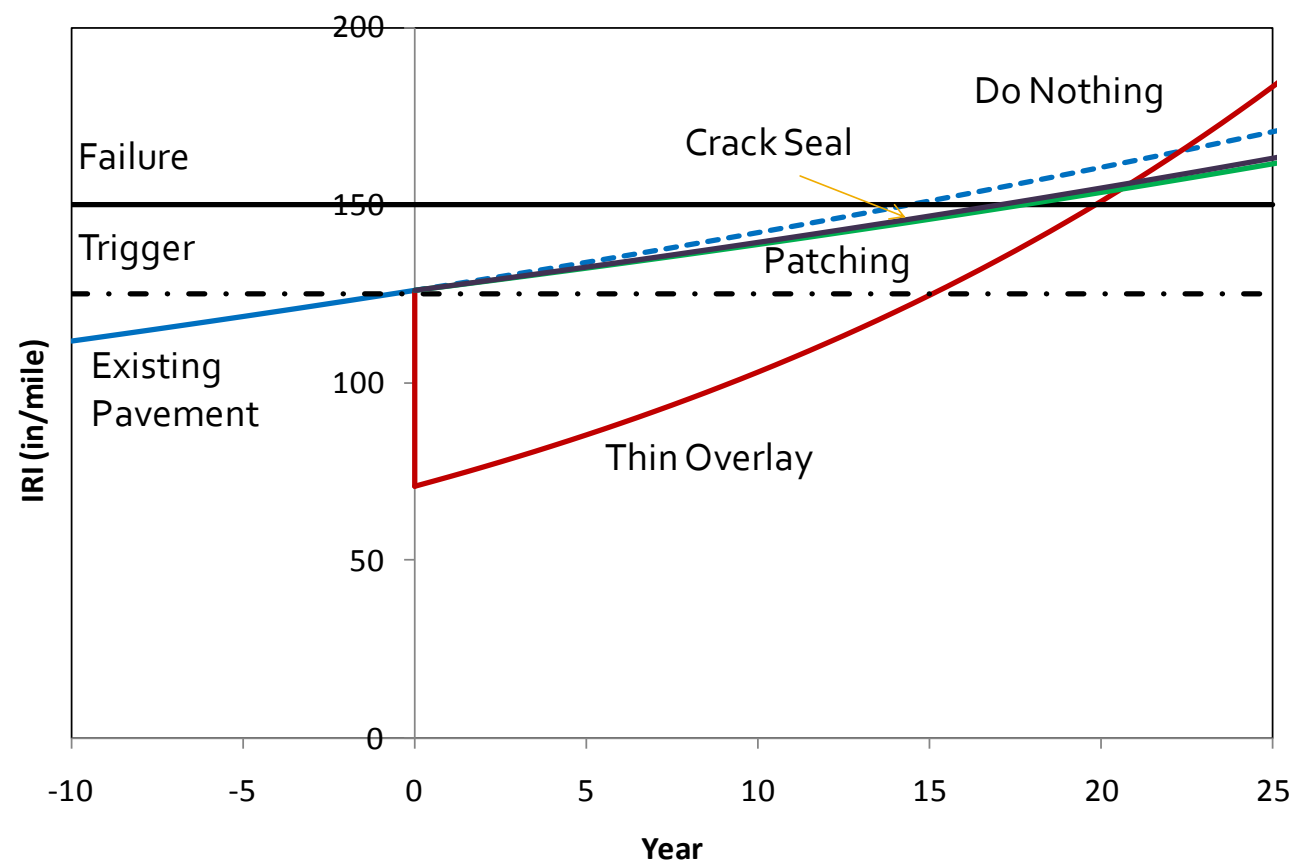

Figure 5.5: Comparison of preservation strategies on pavement performance 
Table 5.6: Comparison of Selection Metric for Different Pavement Treatments

\begin{tabular}{|l|c|c|c|c|}
\hline Case & $\begin{array}{l}\text { Remaining } \\
\text { Service Life RSL }\end{array}$ & $\begin{array}{l}\text { Remaining Service } \\
\text { Life Extension RSLE }\end{array}$ & $\begin{array}{l}\text { Cost } \\
\text { Effectiveness } \\
\text { per RSL }\end{array}$ & $\begin{array}{l}\text { Cost } \\
\text { Effectiveness per } \\
\text { RSLE }\end{array}$ \\
\hline Do Nothing & 14 years & - & - & - \\
\hline Routine Crack Seal & 15 years & 1 year & $\$ 866$ & $\$ 13,000$ \\
\hline Routine Patching & 16 years & 2 years & $\$ 2,345$ & $\$ 37,519$ \\
\hline Thin PM Overlay & 20 years & 6 years & $\$ 3,125$ & $\$ 10,419$ \\
\hline HMA Overlay & 23 years & 9 years & $\$ 9,003$ & $\$ 23,009$ \\
\hline
\end{tabular}

\subsection{Chapter Summary}

This chapter has developed long and short term performance models for pavement preservation treatments. These models can be implemented in the Indiana pavement management system for inclusion of pavement preservation concepts in network level PMS. Furthermore, a remaining service life concept to evaluate competing pavement strategies at the project level is developed. An illustration is presented in the chapter and it is found that in general, pavement preservation can be a cost-effective solution to preserve our pavement assets on a project level. 


\title{
CHAPTER 6: PAVEMENT PRESERVATION FRAMEWORK FOR A STATE HIGHWAY AGENCY
}

\author{
$\underline{6.1 \quad \text { Introduction }}$
}

The previous sections have described the development of triggers and performance models for use in a network level pavement management system. However, there still exists a gap before districts can implement pavement preservation concept in their operations. In this chapter, a pavement preservation framework for implementation at the district level is developed. Special focus is paid on the interaction between the central office and the individual districts and the best business practices conducive for the implementation of pavement preservation. First, the framework for pavement preservation implementation at the district level is described. Second, an optimization approach using remaining service life is proposed to allow selection of pavement preservation projects within the network. Last, a demonstration of pavement preservation in preserving highway assets in the network is provided.

\subsection{A Framework for Pavement Preservation Implementation}

In order for pavement preservation to be effective, it is insufficient to implement the concept solely at the project level (for example, preservation treatment selection for individual road sections) or at the network level (for example, network level planning of treatments). Furthermore, there needs to be an interaction between project and network levels, and between the central office and the districts. This section therefore presents a comprehensive framework for pavement preservation for the state highway agency and lists the best business practices for any state highway agency to adopt when implementing the pavement preservation concept.

Figure 6.1 describes the proposed framework for the state highway agency. Some of the important elements include: network analysis at the central office and evaluation of remaining service life (RSL) of the state highway network, selection of candidate projects at the central office and dissemination to the districts, district-level analysis and selection of potential candidates for preservation treatments, feedback to central office for approval and implementation at the districts. 
CENTRAL OFFICE

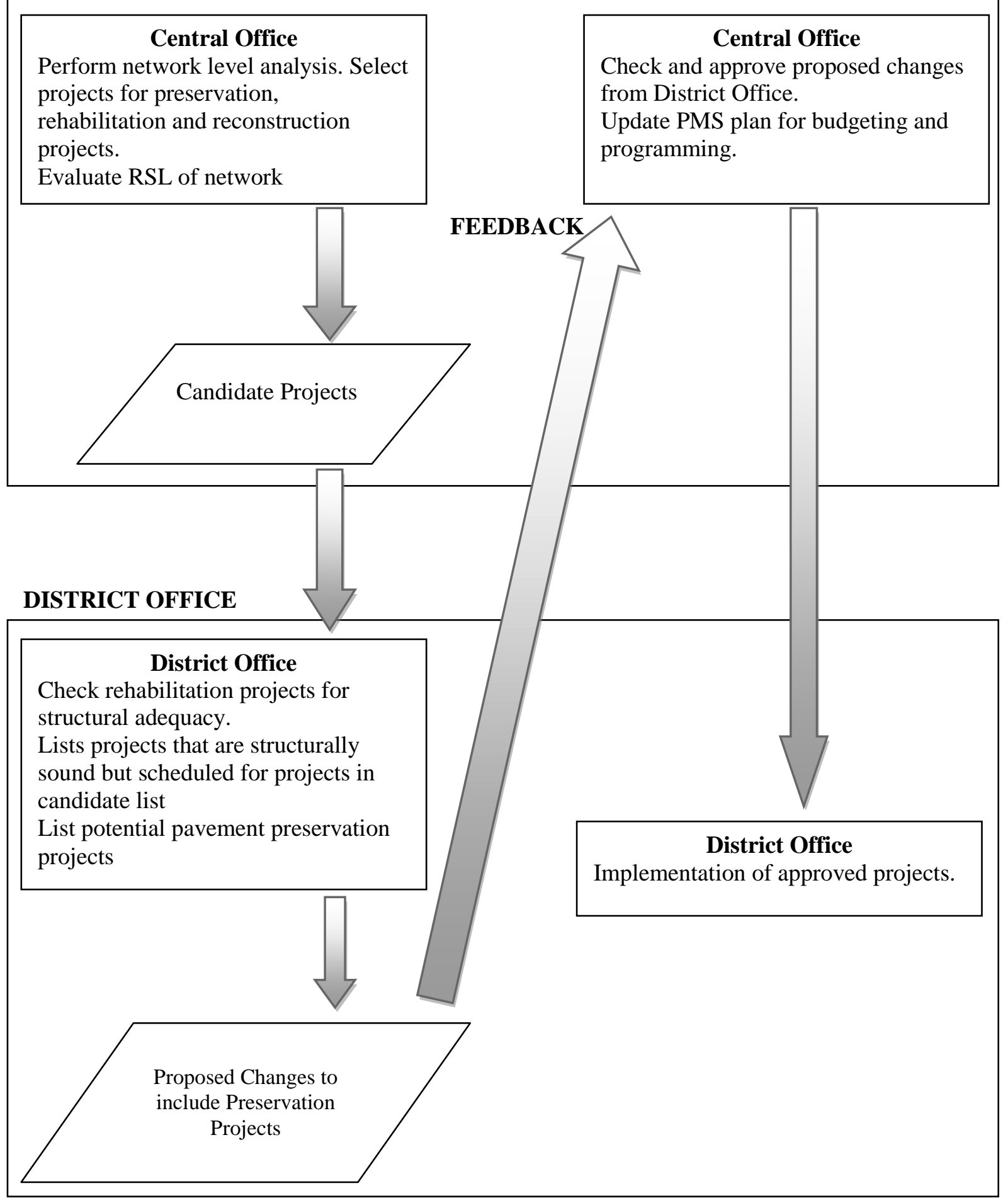

Figure 6.1: Pavement preservation planning within the pavement management system framework 
There are four main steps in the proposed framework as illustrated in Figure 6.1. A discussion on each step is provided in the following discussion:

Step 1: Network Level Analysis at the Central Office

For a given year, network level analysis can be performed within the central office to determine which pavement sections are to undergo preservation, rehabilitation and reconstruction. Particularly for preservation treatments, the performance models and triggers developed in the earlier chapters should be implemented within the pavement management system framework to select potential preservation, rehabilitation and reconstruction projects. Once the candidate projects are selected, they are sent to the district office for dissemination and verification. At this point a preliminary RSL distribution can be determined for the entire network.

Step 2: Network Level Analysis at the District Office

One problem with network level analysis at the central office is that structural conditions might not be explicitly included in the formulation. For example, IRI might be used as the main trigger for pavement rehabilitation actions and there is always a possibility that a pavement without structural failure ends up being scheduled for rehabilitation (where in fact preservation may be a much better alternative). Hence there is a need for the districts to check the candidate list given by the central office to make sure that the projects indeed suffer from structural failure (see Figure 6.2). Structural tests can be performed using core sampling or falling weight deflectometer testing. For projects which consist of structurally deficient pavements, the scheduled rehabilitation work will go on as planned. For projects which consist of functionally deficient pavements, it is being inputted to another candidate list for potential use of pavement preservation treatments.

The districts should also have a set of potential sections or projects suitable for pavement preservation. The type of treatment to be performed could be identified using the guidelines described in Chapter 4. This would also provide potential candidates for pavement preservation project selection, as shown in Figure 6.2.

The combined candidate list will provide a platform for district to select projects that have to be implemented. Once the preservation projects are selected, they are sent to the district office for feedback. At this point an RSL distribution can be determined for the candidate project list.

\section{Step 3: Feedback to Central Office and Implementation at Districts}

At this point, if the proposed changes are acceptable, the PMS plan can be updated and implemented at the districts. 


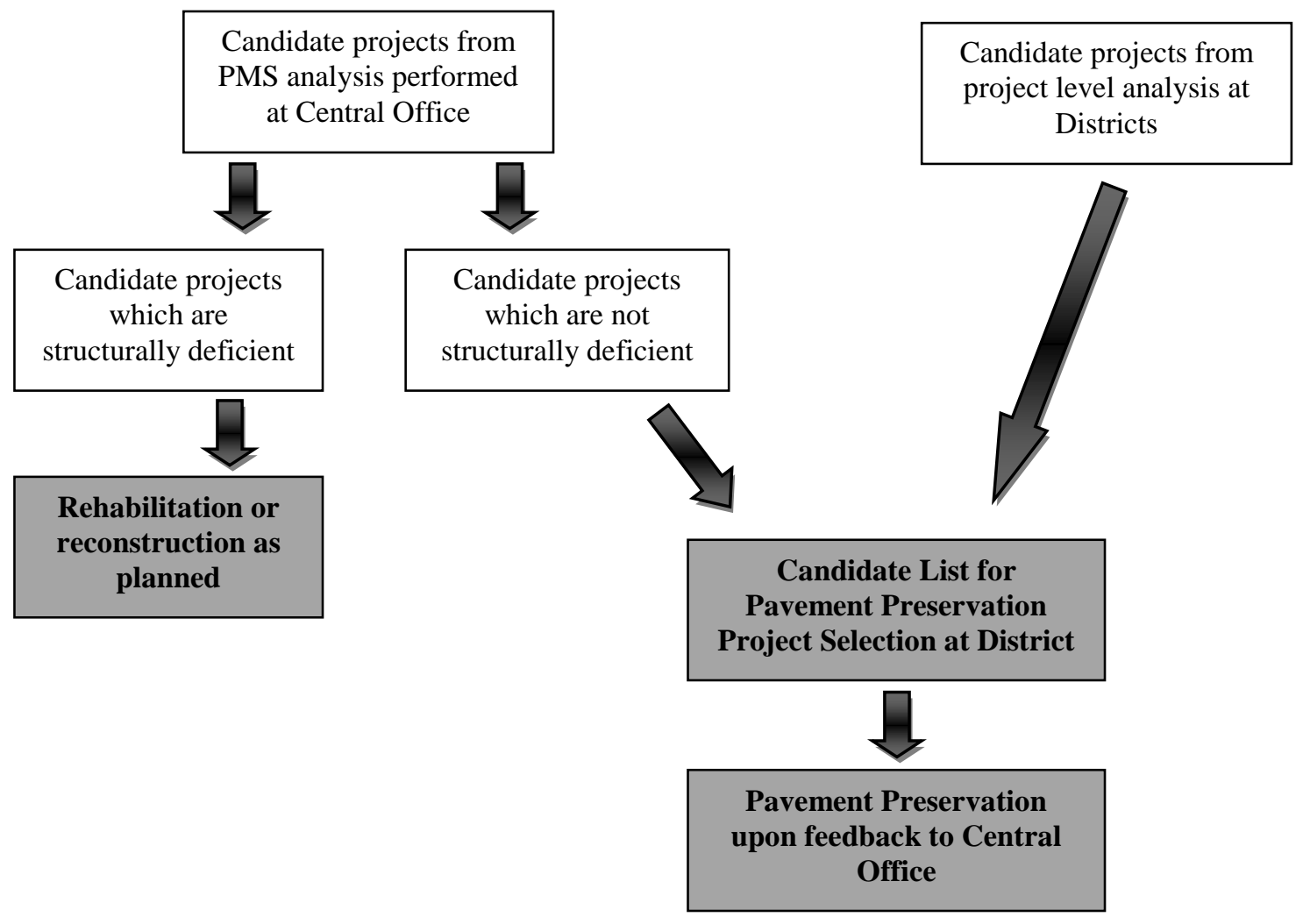

Figure 6.2: Candidate project selection

\subsection{Preservation Project Selection at the District Level}

It is noted that there is a need to perform some form of optimization when selecting the best set of projects for pavement preservation. At the central office, there is typically a software system enabling network optimization of pavement projects to meet certain agency objectives (such as maximizing benefits, cost-effectiveness and remaining service life). At the district offices, there is currently a lack of tools for them to select projects using an optimization approach. This section therefore presents a model for districts to select pavement projects subject to a set of candidate lists (as shown in Figure 2 and Step 2 in the previous section) targeted to improve the remaining service life of their network.

Figure 6.3 illustrates the framework of the study approach. For the given pavement deterioration models, the short and long term characteristics of pavement treatments and assumed threshold levels for different performance measures (IRI, PCR and rut depth), the remaining service life and its extension due to a treatment can be determined:

$R S L_{b}=t_{1}-t_{0}$ 
$R S L_{a}=t_{2}-t_{0}$

$R S L E=R S L_{a}-R S L_{b}=t_{2}-t_{1}$

Note that in this case, $R S L_{b}$ is the remaining service life of the pavement if no treatment is performed.

RSLE is essentially the benefit brought to the pavement section by performing a particular treatment.

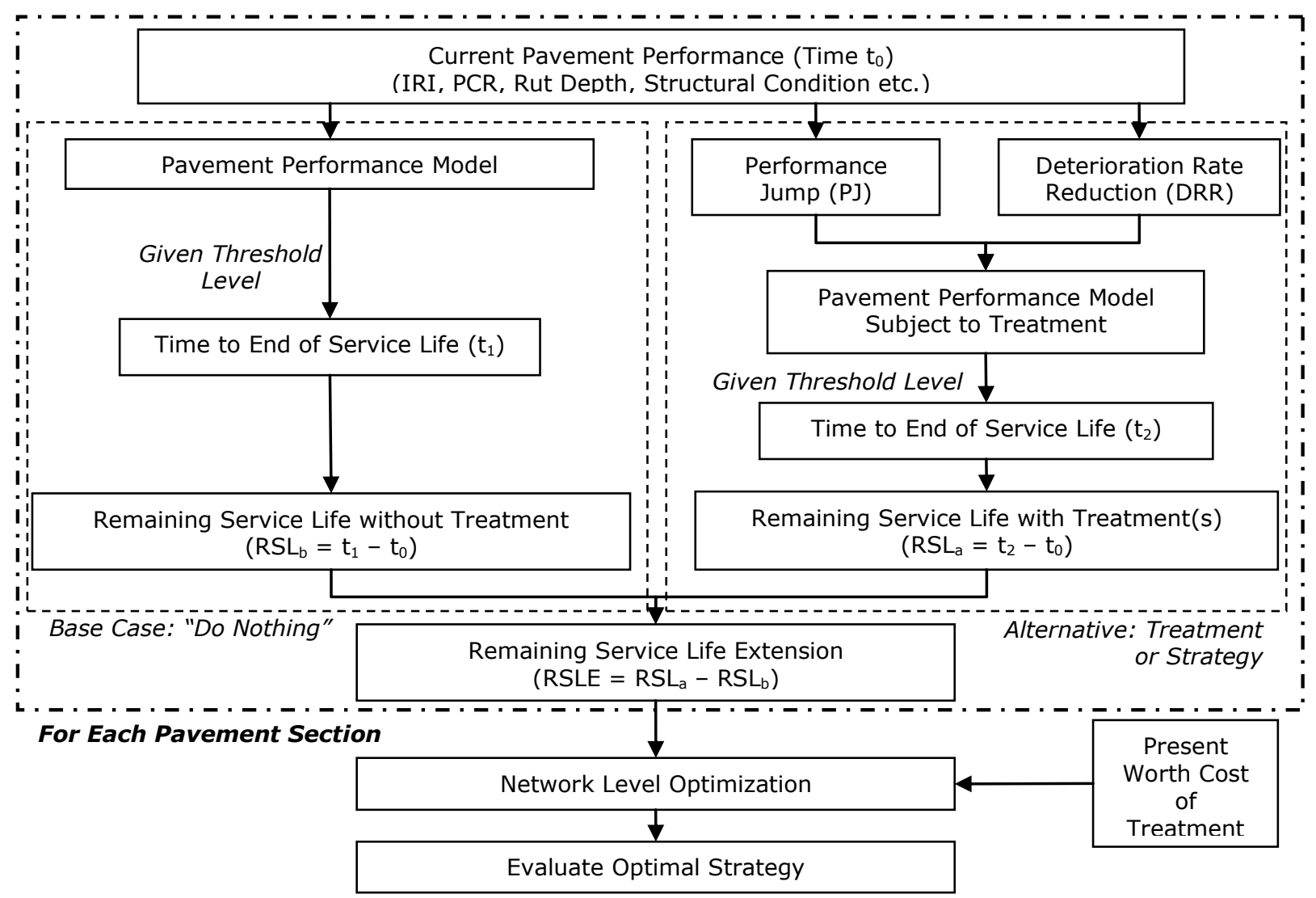

Figure 6.3: Selecting optimal pavement preservation strategy

For a known present worth value of treatment cost, network-level optimization can be performed to optimize the remaining service life extension (RSLE) of the entire pavement network in the candidate list. The mathematical formulation of the problem can be summarized below:

$\operatorname{Max} \quad R S L E=\Sigma\left(y_{i j} \times R S L E_{i j}\right)$

such that $\quad \Sigma_{\mathrm{j}}\left(y_{i j} \mathrm{x} c_{i}\right) \leq$ Budget

$$
\begin{aligned}
& \mathrm{IRI}_{\mathrm{aj}} \geq \mathrm{IRI}_{\mathrm{t}} ; \mathrm{PCR}_{\mathrm{aj}} \leq \mathrm{PCR}_{\mathrm{t}} ; \mathrm{Rut}_{\mathrm{aj}} \geq \mathrm{Rut}_{\mathrm{t}} \text { for all } j \\
& \Sigma_{\mathrm{i}} y_{i j}=1 \text { for all } \mathrm{j} \\
& y_{i j}=0 \text { or } 1
\end{aligned}
$$


where $R S L E_{i j}$ is the remaining service life extension for treatment $i$ and project $j$ (as defined in Equation (5)); $y_{i j}$ is a binary variable indicating if project $\mathrm{j}$ is selected; $c_{i}$ is the cost associated with the project; $\operatorname{IRI}_{\mathrm{aj}}$, $\mathrm{PCR}_{\mathrm{aj}}$ and $\mathrm{Rut}_{\mathrm{aj}}$ are IRI, PCR and rut depths for project $\mathrm{j}$ with treatment; and $\mathrm{IRI}_{\mathrm{t}}, \mathrm{PCR}_{\mathrm{t}}$ and $\mathrm{Rut}_{\mathrm{aj}}$ are threshold IRI, PCR and rut depths. The above formulation is a integer programming problem and can be solved using standard optimization techniques or PMS software.

An Excel-solver is developed to solve the above stated optimization problem. Appendix III provides a tutorial on how to apply the optimization tool at the district level to choose pavement preservation projects using Microsoft Excel. Figure 6.4 shows a screenshot of the spreadsheet detailing the candidate projects and their information on traffic, weather, RSL and proposed treatment. As mentioned in the previous section, the candidate projects are based on the Central Office's input and the district needs.

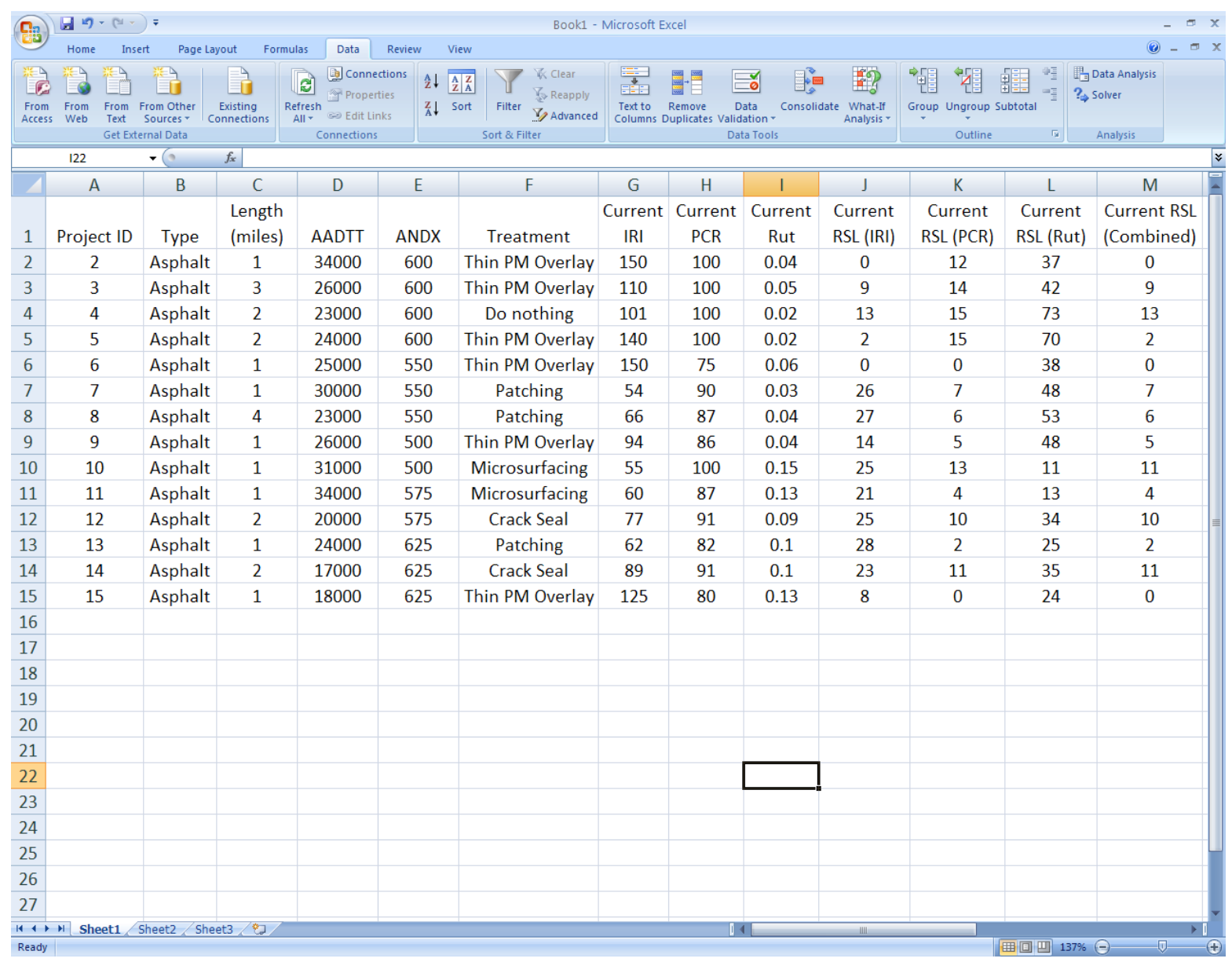

Figure 6.4: Candidate sections and their current conditions in the Excel spreadsheet 
Figure 6.5 illustrates the screenshot of the spreadsheet detailing the optimal solution after running the Excel solver. The optimal solution is then fed back to the central office ( 1 represents project is selected, 0 otherwise). It can be seen clearly that that the proposed Excel spreadsheet tool provides a convenient means for district engineers to select the pavement preservation projects on their desktops.

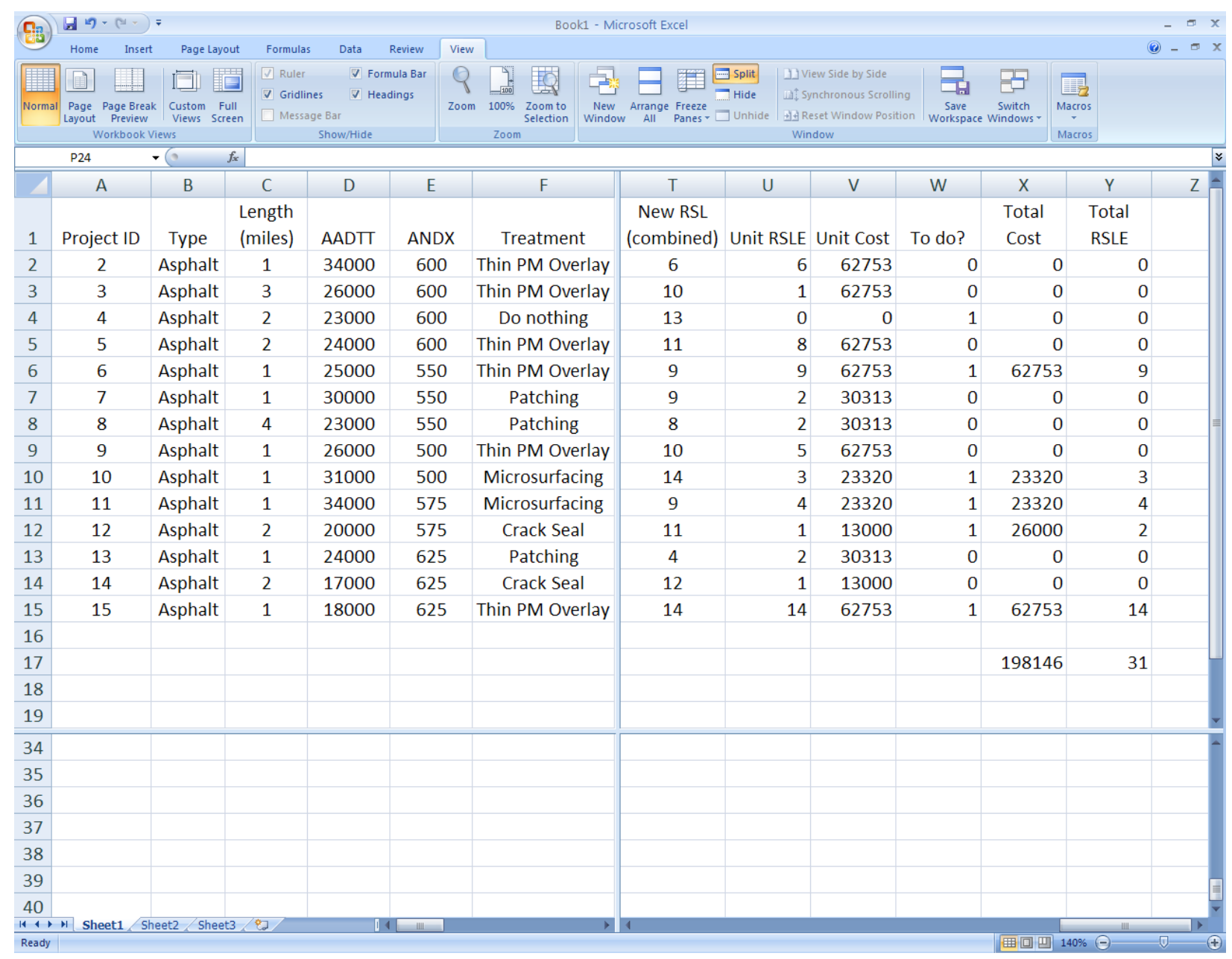

Figure 6.5: Optimal solution for feedback to central office

\subsection{Demonstration of Applied Framework}

The proposed framework described in Figure 6.1 is applied to a sample highway network consisting 50 miles within a district in Indiana. Information on pavement condition, traffic level, environmental conditions, and construction cost are extracted from the Indiana Department of Transportation (INDOT) pavement management database. Distributions of the pavement conditions (in terms of IRI, PCR and rut depth respectively) are shown in Figure 2. It is noted that $10 \%$ of the network is classified as "poor" 
(exceeding threshold levels: $\mathrm{IRI}_{\mathrm{t}}=150$ inches per mile, $\mathrm{PCR}_{\mathrm{t}}=80$ or Rut $_{\mathrm{t}}=0.25$ inch), this is where a major rehabilitation is triggered. Pavements in fair conditions are normally triggered for preservation treatments whereas those in excellent conditions typically require no treatment, should the "worst pavement first approach" be used.

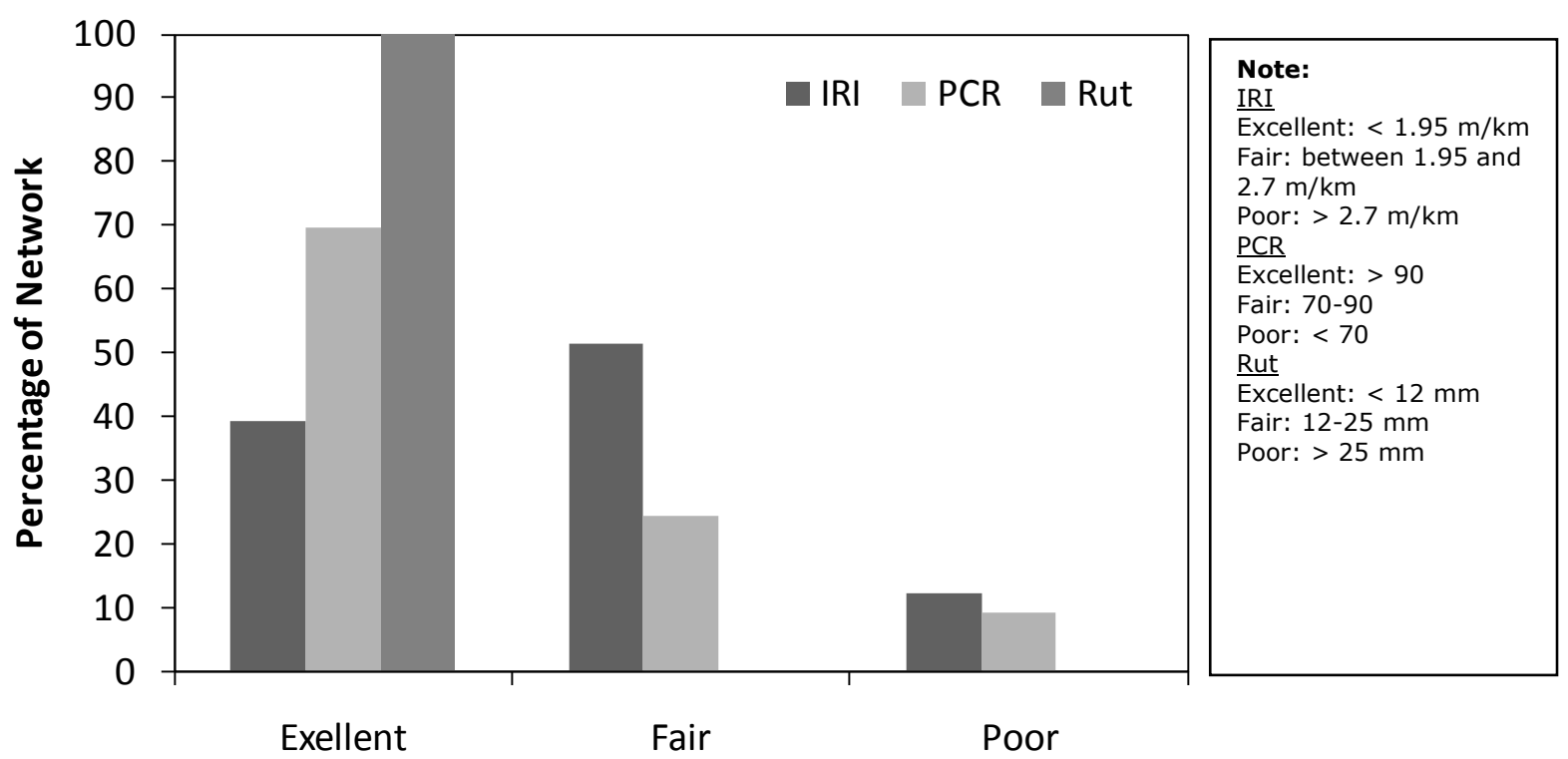

Figure 6.4: Distribution of pavement conditions in sample network

Four different alternatives are considered in the paper: do nothing, crack seal, thin asphalt overlay, and asphalt structural overlay. It is noted that crack seal and thin asphalt overlay are considered as preservation treatments while asphalt structural overlay is a major rehabilitation treatment. The short term and long term performance models for each treatment and their associated costs presented in Chapter 5 are used in the analysis.

Figure 6.5(a) presents the optimal distribution of treatments at different budget levels $(\$ 200,000$ $\$ 600,000)$ obtained from the proposed optimization framework. It can be observed that preservation treatments (crack seal and thin overlay) accounts for more than $50 \%$ of the treatments at all budget levels. The "worst pavement first" approach (Figure 6.5(b)), on the other hand, results in a higher proportion structural overlays for pavements in poor condition when compared to the proposed framework, leaving a consideration portion of the network without any form of treatment. The finding suggests that the use of remaining service life concept in the proposed framework tends to favor preservation treatments over rehabilitation treatments when maximizing the overall network benefit (in terms of remaining service life extension). 


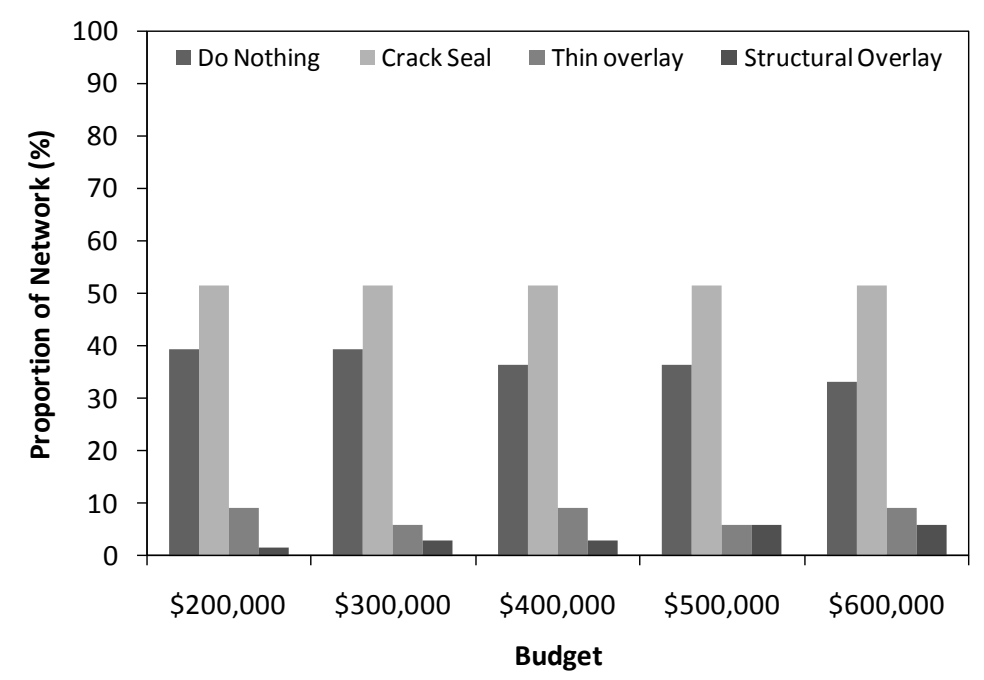

(a) Proposed framework

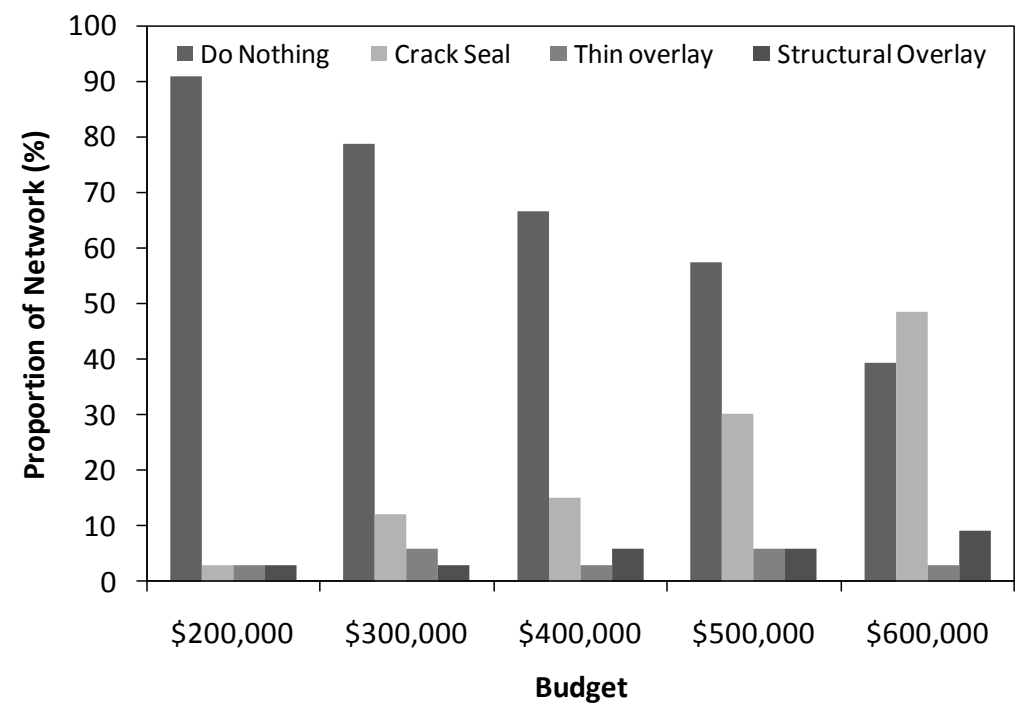

(b) "Worst pavement first" approach

Figure 6.5: Optimal pavement strategy using proposed framework and "worst pavement first" approach

Figure 6.6 further compares the remaining service life extension (RSLE) for the entire network obtained from the proposed framework against that obtained from the "worst pavement first" approach. It is observed that for all budget levels, the proposed framework is capable of allocating budget to maximize the remaining service life extension of the network. This represents the essence of pavement preservation - using frequent preservation treatments in lieu of costlier rehabilitation treatments to extend the remaining service life of pavement assets. 


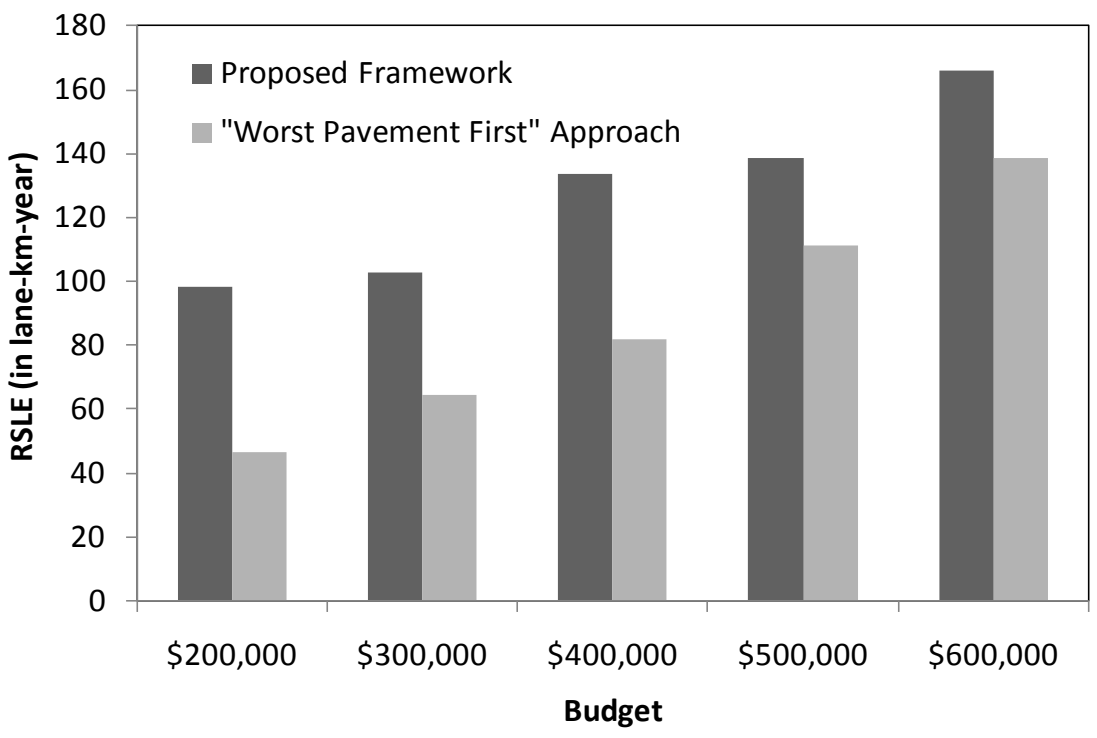

Figure 6.6: RSLEs for proposed framework and "worst pavement first" approach

\subsection{Chapter Summary}

This chapter has presented a pavement preservation framework that integrates project level evaluation at the districts and network level evaluation at the central office. The remaining service life approach is adopted in the selection of pavement preservation projects. An Excel-based spreadsheet is developed to allow district engineers the ease of selecting pavement preservation projects at their desktop. Using a sample highway network from the state of Indiana, it is found that the proposed framework is capable of improving the remaining service life of the pavement network as compared to the traditional "worse pavement first" concept. It is demonstrated in the case study that by advocating the pavement preservation concept, agencies can look forward to enjoy a much better remaining service life extension to highway pavement assets when compared to the traditional "worst pavement first" approach. 


\title{
CHAPTER 7: CONCLUSIONS AND RECOMMENDATIONS
}

\author{
7.1 Summary of Main Findings
}

State highway agencies are facing immense pressure to maintain roads at acceptable levels amidst the challenging financial and economic situations. In recent years, pavement preservation has been sought as a potential alternative for managing the pavement assets, believing that it would provide a cost-effective solution in maintaining infrastructural conditions and meeting user expectations. This study explores the potential of pavement preservation concepts in managing the agency's pavement assets. A literature review was performed to understand the state-of-the-art and state-of-practice in implementing pavement preservation at the project levels and network levels. While the concept itself is found to be pretty established on the project level, there is still a significant gap in implementing elements of pavement preservation at the network level, especially within the pavement management system. Recognizing the need to integrate both project and network level pavement preservation into a coherent pavement management structure, this research study attempts to prescribe a framework for pavement preservation implementation within a state highway agency.

This study attempts to provide means to integrate pavement preservation considerations within the network-level pavement management system. Several elements are studied in the report: (i) determining triggers for pavement preservation treatments for use in a PMS, (ii) development of performance models for preservation treatments, (iii) developing a remaining service life approach for strategy comparison at the project level, and (iv) developing a pavement preservation framework that integrates the districts and the central office of a state highway agency.

The first part of the study effort calls for the development of thresholds or decision matrices that allow the "triggering" of preservation and rehabilitation treatments. This enables the highway agency to consider preservation treatments in their planning and budgeting process, and hence promote a more long term (and sustainable) view of pavement preservation. Two different procedures to develop intervention levels for pavement preservation treatments are studied. The first procedure involves using historical decisions made by an agency to determine treatment intervention levels, while the second procedure seeks expert opinions to develop relevant treatment decision matrices. Based on the findings of the report, the 
procedure using distress-based decision matrices are found to be more desirable, primarily because it can be easily adopted for new and innovative pavement materials and treatments.

The second part of the study effort aims to develop pavement performance models (both long term pavement performance and short term performance jumps) that can be directly inputted into the existing pavement management systems used by highway agencies. Using pavement condition data, weather data, traffic data, work and contract management information, long and short term effectiveness models are developed for common asphalt and PCC pavement preservation treatments in Indiana. Costs for preservation treatments are also identified.

A remaining service life approach for pavement preservation strategy selection is developed to evaluate competing pavement strategies at the project level. An illustration is presented in study and it is found that in general, pavement preservation can be a cost-effective solution to preserve our pavement assets on a project level.

The last part of this report presented a pavement preservation framework that integrates project level evaluation at the districts and network level evaluation at the central office. The remaining service life approach is adopted in the selection of pavement preservation projects. An Excel-based spreadsheet is developed to allow district engineers the ease of selecting pavement preservation projects at their desktop. Using a sample highway network from the state of Indiana, it is found that the proposed framework is capable of improving the remaining service life of the pavement network as compared to the traditional "worse pavement first" concept. This demonstrates the effectiveness of the pavement preservation concept where agencies can look forward to enjoy a much better remaining service life extension to highway pavement assets when compared to the traditional "worst pavement first" approach.

In sum, pavement preservation can be a viable alternative for agencies to manage their pavement assets. However, challenges still remain in implementation as noted from the proposed pavement preservation framework. There needs to be close communication and interaction between the pavement management engineers and the maintenance crews, close links between the central office engineers and the district pavement engineers, and more importantly a close exchange in information (pavement, traffic, structural condition and others) between all elements of the state highway agency. This is absolutely critical for the successful implementation of a comprehensive preservation-oriented pavement management system. 


\subsection{Recommendations for Future Research}

Several recommendations can be made for future research. This includes:

- Inclusion of rehabilitation and reconstruction treatments in the analysis framework. This study only covers the preservation treatments and ignores the consideration of rehabilitation and reconstruction activities at the network level.

- Inclusion of economy of scale of performing preservation treatments. A larger project tends to have a better economy of scale and this should be reflected in the preservation framework.

- Inclusion of more detailed pavement structural information for analyses. This includes more frequent falling weight deflections or other structural indices on both the temporal and spatial domain.

- Development of an integrated pavement preservation software which connects network level PMS to project level PMS. 


\section{LIST OF REFERENCES}

Abaza, K.A. and Ashur, S.A. (1999). Optimum Decision Policy for Management of Pavement Maintenance and Rehabilitation. Transportation Research Record 1655, 8-15.

ACPA. (1998). The Concrete Pavement Restoration Guide-Procedures for Preserving Concrete Pavements, American Concrete Pavement Association.

ASCE. (2009). Report Card for America's Infrastructure 2009. American Society of Civil Engineers.

Bekheet, W., K. Helali, T. Kazmierowski and N. Li. (2005). Integration of Preventive Maintenance in the Pavement Preservation Program: Ontario Experience. In Transportation Research E-Circular No. E-C078, Washington D.C., pp. 87-98

Berg, Ken; Burns, Kelly; Sharp, Barry. (2009). Type III Micro Surfacing to Extend the Life of Concrete Pavement on I-70 in Region Four. Final Report. UT-09.03. Utah DOT.

Caltrans. (2003). Maintenance Technical Advisory Guide (MTAG) - Asphalt Pavements, Sacramento. http://www.dot.ca.gov/hq/maint.

Caltrans. (2007). Maintenance Technical Advisory Guide (MTAG) - Asphalt Pavements, Sacramento. http://www.dot.ca.gov/hq/maint.

Chou, E.Y.J, Pulugurta, H. and Datta, D. (2008). Pavement Forecasting Models. FHWA/OH-2008/3. Final Report. Prepared for the Ohio Department of Transportation. University of Toledo.

Cullocis-Rio, B, K. C. Sinha and E. J. Yoder. (1984). Development of a Method for Establishing Resurfacing Priorities for the Pavement Management in Indiana: Volume 2, Study Procedures and Results. FHWA/IN/JHRP-84-10-2. Purdue University, West Lafayette, IN.

Feighan, K., K. C. Sinha and T. White. (1986). Assessment of Routine Maintenance Needs and Optimal Use of Maintenance Funds: An Estimation of Service Life and Cost of Routine Maintenance Activities. FHWA/IN/JHRP-86-09. Purdue University, West Lafayette, IN.

FHWA. (1990). Advanced Course in Pavement Management Systems, Course Notebook, Federal Highway Administration Newsletter, Washington, DC.

FHWA (1999). Asset Management Primer. Washington D.C. 
FHWA (2005). Pocket Guide to Asphalt Pavement Preservation. Washington D.C.

Fwa, T. F. and K. C. Sinha. (1985). A Routine Maintenance and Pavement Performance Relationship Model for Highways, Informational Report. FHWA/IN/JHRP-85-11. Purdue University, West Lafayette, IN.

Fwa, T. F., and Sinha, K. C. (1987). An aggregate damage approach for highway pavement performance Analysis. Tech. Rep. No. FHWA/JHRP-87-15, Joint Highway Research Project, Purdue Univ., West Lafayette, Ind.

Fwa, T. F., Riverson, J. D. N. and Sinha, K. C. (1988). Priority Assessment for Routine Maintenance Needs and Optimal Programming. FHWA/IN/JHRP-88-1. Purdue University, West Lafayette, IN.

Galehouse, L., J. S. Moulthrop and R. G. Hicks. (2003). Principles of Pavement Preservation. In TR News, September/October 2003 Issue.

Geoffroy, D.N. (1996). Synthesis of Highway Practice 223: Cost-effective Preventive Pavement Maintenance. Transportation Research Board, National Research Council, Washington, D.C.

Haas, R., Hudson, W.R. and Zaniewski, J.P. (1994). Modern Pavement Management. Krieger Publishing Company, Malabar, Florida.

Hicks, R.G., S.B. Seeds and D.G. Peshkin. (2000). Selecting a Preventive Maintenance Treatment for Flexible Pavements. Technical Report for Foundation for Pavement Preservation and Federal Highway Administration Washington D.C.

INDOT. (1997). Pavement Condition Data Collection Manual.

INDOT (2009). Indiana Department of Transportation Design Manual Chapter 52. Indianapolis, IN.

Irfan, M., Kurshid, M.B., Labi, S. and Flora, W. (2009). Evaluating the Cost Effectiveness of Flexible Rehabilitation Treatments Using Different Performance Criteria. ASCE Journal of Transportation Engineering, Vol. 135 No. 10, pp. 753-763.

Gao, L. and Z. Zhang. (2009). Robust Optimization for Managing Pavement Maintenance and Rehabilitation. Transportation Research Record 2084, 55-61.

Hicks, R.G., F. Dunn, K. and J.S. Moulthrop. (1997). Framework for Selecting Effective Preventive Maintenance. Transportation Research Record 1597, 1-10

Hicks, R.G., S.B. Seeds and D.G. Peshkin. (2000). Selecting a Preventive Maintenance Treatment for Flexible Pavements. Technical Report for Foundation for Pavement Preservation and Federal Highway Administration Washington D.C.

Johnson, K. D., and Cation, K. A. (1992). Performance Prediction Development using Three Indexes for North Dakota Pavement Mnagement System. Transportation Research Record, 1344, 23-26.

Kuennen, T. (2005). Making High-Volume Roads Last Longer. In Better Roads, April 2005 Issue. 
Labi, S. and Sinha, K.C. (2003). Effect of Routine Maintenance on Capital Expenditures, JTRP Report, Purdue University, West Lafayette, IN.

Labi, S. and Sinha, K. C. (2006). Measures of Short-Term Effectiveness of Highway Pavement Maintenance. ASCE Journal of Transportation Engineering, Vol. 129, No. 6, 673-683.

Labi, S., G. Lamptey and S. H. Kong. (2007). Effectiveness of Microsurfacing Treatments. ASCE Journal of Transportation Engineering, Vol. 133, No. 5, 298-307.

Lamptey, G, M. Ahmad, S. Labi and K. C. Sinha. (2004). Life Cycle Cost Analysis for INDOT Pavement Design Procedures. FHWA/IN/JTRP-2004-28. Purdue University, West Lafayette, IN.

Lytton, R. L. (1987). Concepts of pavement performance prediction and modeling. Proc., 2nd North American Conf. on Managing Pavements, Vol. 2, Public Roads, Toronto.

Mamlouk, M. S., and Zaniewski, J. P. (1998). Pavement preventive maintenance: description, effectiveness and treatments. Flexible Pavement Rehabilitation and maintenance, ASTM STP 1348, P. S. Kandhal and M. Stroup-Gardner, eds., American Society for Testing and Materials, West Conshohocken, Pa., 121-135.

Markow, M. J. (1991). Life cycle costs evaluations of effects of pavement maintenance. Transp. Res. Rec., 1276, Transportation Research Board, Washington, D.C., 37-47.

Miller, J.S. and W.Y. Bellinger. (2003). Distress Identification Manual for the Long-Term Pavement Performance Program, 4th Edition. FHWA-RD-03-031, Washington D.C.

Mouaket, I., A. Al-Mansour and K. C. Sinha. (1990). Evaluation of the Cost Effectiveness of Pavement Surface Maintenance Activities. FHWA/IN/JHRP-90-12. Purdue University, West Lafayette, IN.

Mouaket, I.M., Sinha, K.C., and White, T.D. (1992). Guidelines for Management of Chip and Sand Seals Coating Activities in Indiana, Transportation Research Record 1344, pp. 85-86.

O’ Doherty, J.D. (2007). At the Crossroads. National Center for Pavement Preservation.

Peterson, D. (1985). Life-Cycle Cost Analysis of Pavements, Synthesis 122. National Cooperative Highway Research Program, Transportation Research Board, National Research Council, Washington, DC.

Rajagopal, A. S., and George, K. P. (1991). Pavement Maintenance Effectiveness. Transportation. Research Record, 1276, 62-66.

Shahin, M.Y. and Walther, J.A. Pavement Maintenance Management for Roads and Streets using the PAVER System, CERL Technical Report M-90/05, Champaign, IL., 1990.

Shiyab, A., Fahim, H.A.A. and Nikraz, H. (2006). New Approaches for Estimation of Flexible Pavement Remaining Life for the Use of PMS. Research into Practice: 22nd ARRB Conference. Australia Road Research Board. 
Shuler, T.S. Asphalt Surface Treatments and Thin Overlays. (1984). NCHRP Synthesis Topic 24-10, Transportation Research Board, National Research Council, Washington, D.C.

Sinha, K. C., T. Al-Suleiman, K. Ksaibati, K. Feighan, F. Montenegro and R. Tandon. (1988). Assessment of Routine Maintenance Needs and Optimal Use of Routine Maintenance Funds. FHWA/IN/JHRP-88-18. Purdue University, West Lafayette, IN.

Sinha, K. C., S. Labi, M. Rodriquez, G. Tine and R. Dutta. (2005). Procedures for the Estimation of Pavement and Bridge Preservation Costs for Fiscal Planning and Programming. FHWA/IN/JTRP-2005-17. Purdue University, West Lafayette, IN.

Smith, K.D., T.E. Hoerner and D.G. Peshkin. (2008). Concrete Pavement Preservation Workshop Reference Manual. Prepared for the Federal Highway Administration.

Uddin, W. Pavement Management Systems. In Handbook of Highway Engineering, edited by T. F. Fwa. CRC Press, Florida, 2006.

Wu, Z.., G.W. Flintsch and T. Chowhudry. (2008). Hybrid Multiobjective Optimization Model for Regional Pavement-Preservation Resource Allocation. Transportation Research Record 2084, 2837.

Wu, Z., R. Shekharan, T. Chowdhury, B.K. Diefenderfer. (2009). Development and Implementation of Network-Level Selection of Pavement Maintenance and Rehabilitation Strategy: Virginia Practice. In Transportation Research Board 88th Annual Meeting Compendium of Papers. DVD. Transportation Research Board of the National Academies, Washington D.C.

Yang, J. (2009). Development of Effective Remaining-Life Prediction Models for Pavement Management at the Network Level. Transportation Research Board 88th Annual Meeting.

Zimmerman, K. and D. G. Peshkin. (2004). Preferential Treatment. In Roads \& Bridges, June 2004 issue. 
$\underline{\text { APPENDIX I }}$

QUESTIONAIRRE FOR EXPERT OPINION SURVEY 


\section{THRESHOLD VALUES FOR PAVEMENT TREATMENTS}

JTRP SPR-3092 Indiana Pavement Preservation Program, INDOT/Purdue University Prepared by: G. P. Ong and K. C. Sinha (Purdue) and T. Nantung (INDOT)

\section{RESPONDENT'S INFORMATION}

NAME OF RESPONDENT:

POSITION/DIVISION:

E-MAIL:

CONTACT NO.:

\section{OBJECTIVES OF SURVEY}

This questionnaire is part of an ongoing study that is developing a pavement preservation program methodology for the state of Indiana. The purpose is to solicit expert opinions from pavement managers, engineers and technicians such as you on the minimum level of pavement condition at which a particular treatment or a set of treatments will be applied.

Information gathered from this survey will be synthesized for the establishment of thresholds as part of the pavement preservation program. We will share the results with you after the entire survey is completed.

\section{BACKGROUND INFORMATION}

\section{PAVEMENT SURFACE TYPES CONSIDERED}

1. Asphalt/Composite

2. PCC

\section{INDICATORS OF PAVEMENT DISTRESS}

1. Pavement Ride Quality and International Roughness Index (IRI)

2. Rut Depth (for asphalt/composite pavements)

3. Fault (for PCC pavements)

4. Crack Severity

Appendix $\mathrm{C}$ describes the distresses considered in this survey.

\section{SELECTION OF TREATMENTS}

A variety of pavement preservation, maintenance, rehabilitation and reconstruction treatments used by INDOT are considered in this survey. You shall be given a set of pavement conditions to decide on the appropriate treatments that you would recommend. Appendices $A$ and $B$ show the treatments that are used by INDOT for asphalt and PCC pavements respectively. Appendices D and E show the description of these treatments for asphalt and PCC pavements respectively. 


\section{PAVEMENT TYPE: Asphalt}

FUNCTIONAL CLASS: Interstates

PAVEMENT PERFORMANCE: Excellent/Good IRI and Ride Quality

For the above stated pavement type, functional class and ride quality. Please indicate the appropriate treatments that you would recommend for the given combination of pavement distresses.

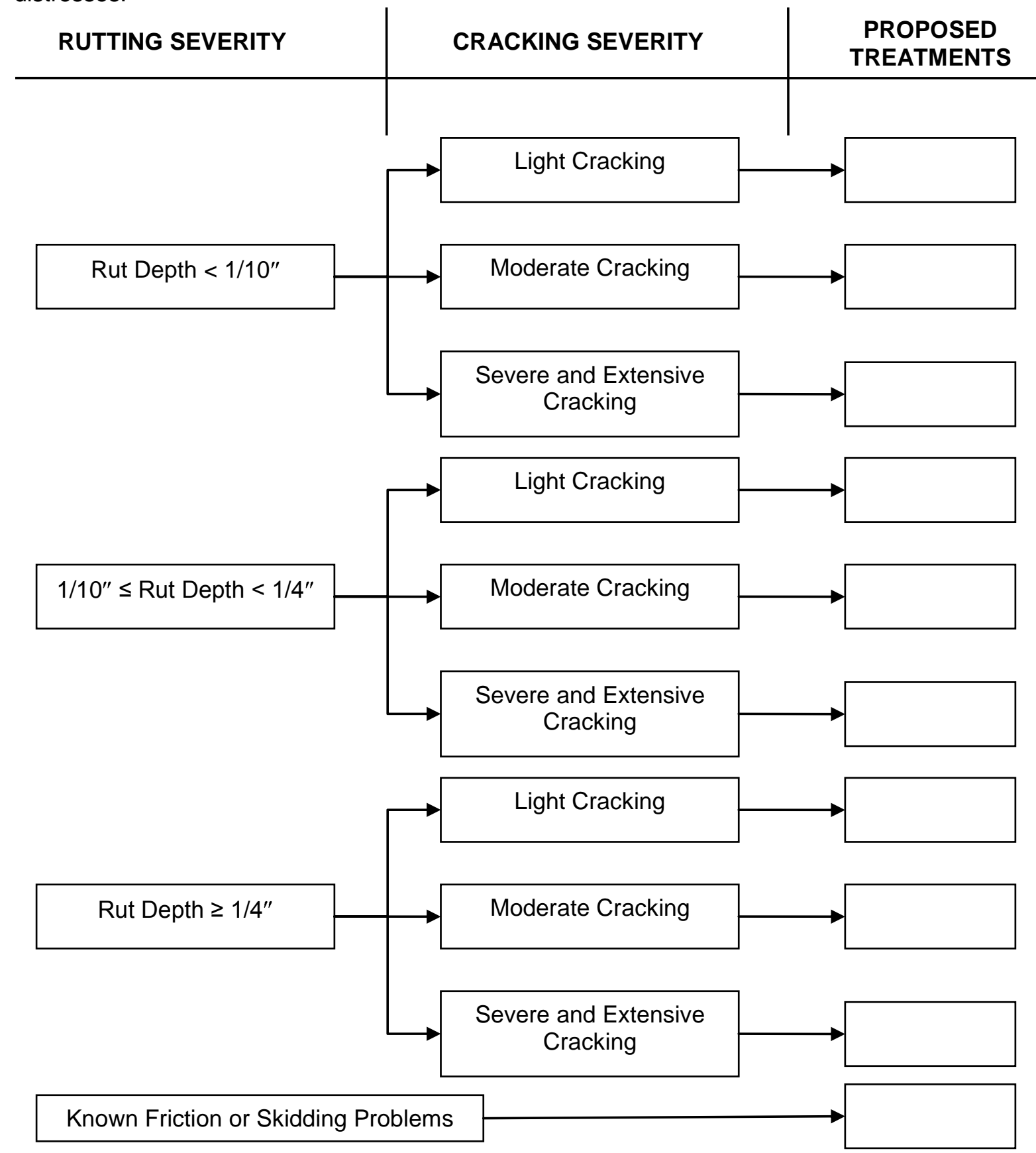

Comments (Use additional sheet if you need more space): 


\section{PAVEMENT TYPE: Portland Cement Concrete}

FUNCTIONAL CLASS: Interstates

PAVEMENT PERFORMANCE: Poor IRI and Ride Quality

For the above stated pavement type, functional class and ride quality. Please indicate the appropriate treatments that you would recommend for the given combination of pavement distresses.

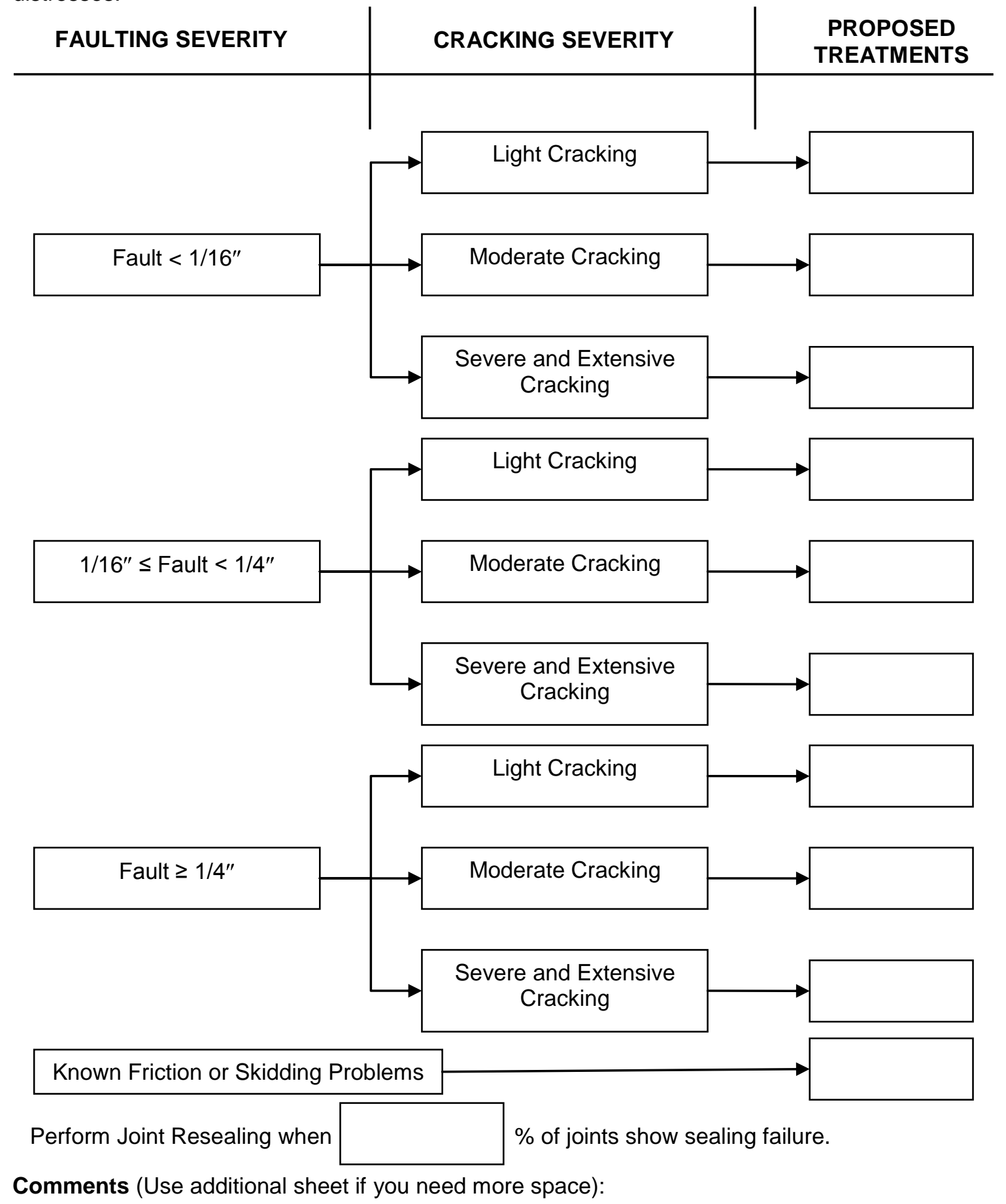




\section{APPENDIX A}

\section{LIST OF PAVEMENT TREATMENTS FOR ASPHALT PAVEMENTS}

This sheet contains the various pavement treatments for asphalt pavements used by INDOT. Use the code on the leftmost column when filling the possible treatments in the questionnaire for ASPHALT PAVEMENTS.

TABLE A1: Pavement Treatments for Asphalt Pavements

\begin{tabular}{|c|l|c|}
\hline CODE & TREATMENT & TYPE OF TREATMENT \\
\hline 01 & Do nothing & None \\
\hline 02 & Crack Sealing & PM \\
\hline 03 & Microsurfacing & PM \\
\hline 04 & Chip Sealing (Single Layer) & PM \\
\hline 05 & Chip Sealing (Double Layers) & PM \\
\hline 06 & Wedge and Level & PM \\
\hline 07 & Mill and Fill (Surface Layer) & PM/ Rehab \\
\hline 08 & Mill and Fill (Functional) & Reconstruction \\
\hline 09 & HMA Structural Overlay & \\
\hline 10 & Asphalt Pavement Replacement & \\
\hline 11 & & \\
\hline 12 & & \\
\hline 13 & & \\
\hline
\end{tabular}




\section{APPENDIX B}

\section{LIST OF PAVEMENT TREATMENTS FOR PCC PAVEMENTS}

This sheet contains the various pavement treatments for PCC pavements used by INDOT. Use the code on the leftmost column when filling the possible treatments in the questionnaire for PCC PAVEMENTS.

TABLE B1: Pavement Treatments for PCC Pavements

\begin{tabular}{|c|l|c|}
\hline CODE & TREATMENT & TYPE OF TREATMENT \\
\hline 01 & Do nothing & None \\
\hline 02 & Crack/Joint Sealing & PM \\
\hline 03 & Diamond Grinding & PM \\
\hline 04 & Load-Transfer Retrofitting & PM \\
\hline 05 & Diamond Grooving & PM \\
\hline 06 & Partial Depth Patching & PM \\
\hline 07 & Full Depth Patching (Asphalt) & Rehab \\
\hline 08 & Full Depth Patching (Concrete) & Rehab \\
\hline 09 & HMA Structural Overlay & Rehab \\
\hline 10 & $\begin{array}{l}\text { PCC Structural Overlay } \\
\text { (Unbonded) }\end{array}$ \\
\hline 11 & $\begin{array}{l}\text { Crack and Seat PCC Slab, and } \\
\text { HMA Overlay }\end{array}$ \\
\hline 12 & Reconstruct PCC Pavement & Reconstruction \\
\hline 13 & & \\
\hline 14 & & \\
\hline 15 & & \\
\hline
\end{tabular}




\section{APPENDIX C}

\section{DEFINITIONS OF PAVEMENT DISTRESS}

This sheet contains the definitions of the terms used in the questionnaire.

\section{PAVEMENT RIDE QUALITY (INTERNATIONAL ROUGHNESS INDEX IRI)}

Pavement ride quality refers to the "bumpiness" of the ride when driving on the pavement section. Technically, the International Roughness Index (IRI) is used to quantify the bumpiness of the ride caused by the longitudinal profile (or commonly known as pavement roughness) of the pavement section. An "excellent or good" ride can be described as a smooth and comfortable ride or drive. Technically, this refers to an IRI of less than $90 \mathrm{inch} / \mathrm{mile}$ for asphalt/composite pavements and 115 inch/mile for PCC pavements. A "poor" ride can be described as an extremely bumpy and uncomfortable ride or drive. Technically, this refers to an IRI of more than 150 inch/mile for all pavements.

\section{RUT DEPTH}

Rutting is the longitudinal depression that occurs in the wheel path. Rut depth is an indicator of the rutting severity.

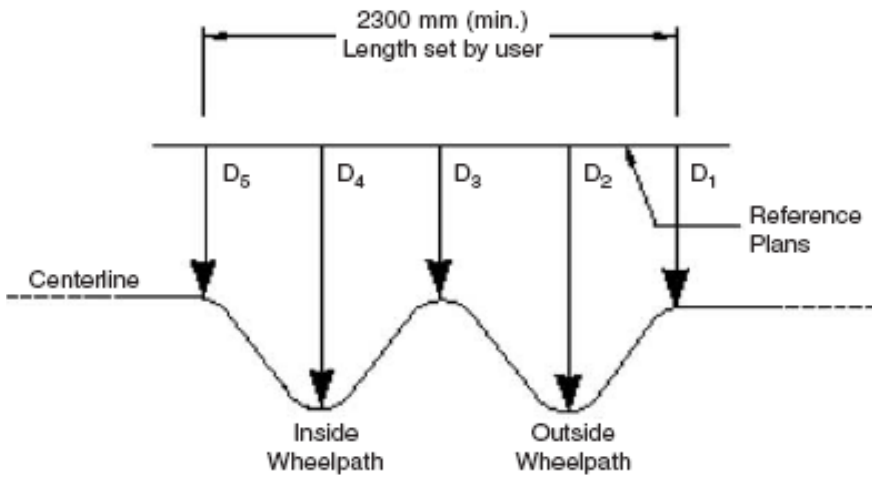

Figure C1 Rut depth measurements

\section{FAULTING}

Faulting is a differential in elevation of two adjacent slabs. Faulting can occur at joints or at random transverse cracks in PCCP.

$P_{1}$ and $P_{2}$ Points to Measure Relative Elevation

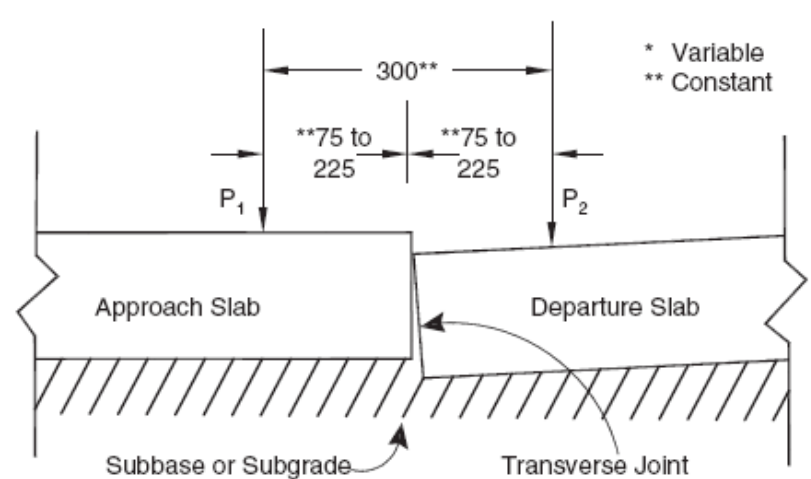

Figure C2 Joint Faulting (measurements in $\mathrm{mm}$ ) 
CRACKING

Cracks are fractured pavement condition resulting from various causes and are found in different forms (transverse, longitudinal, alligator, block cracks etc). This is rated by severity which is determined by visual inspection (using manual inspection methods or semi-automated data collection technique). Cracking is defined as light cracking, moderate cracking and severe cracking in the current INDOT PMS (Pavement Management System) and as shown in Tables $\mathrm{C} 1$ and C2. Refer to the INDOT PMS Manual for more descriptions.

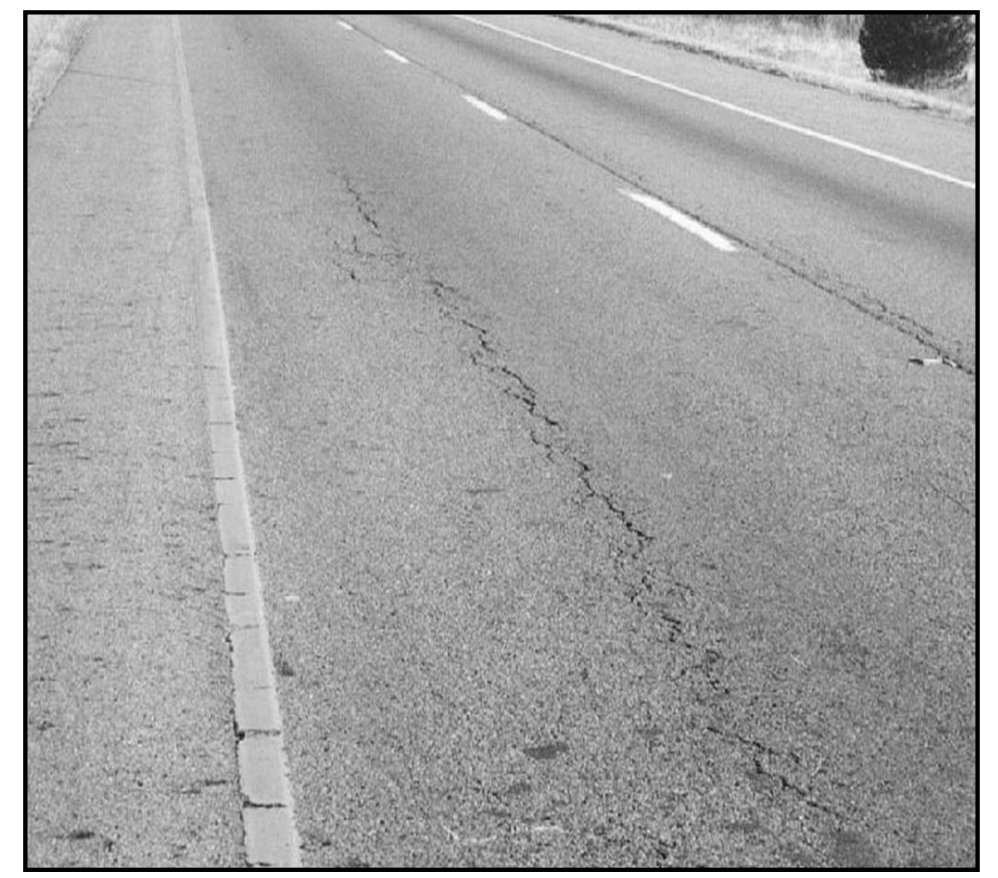

Figure C3 Illustration for Light Cracking on Asphalt Pavements

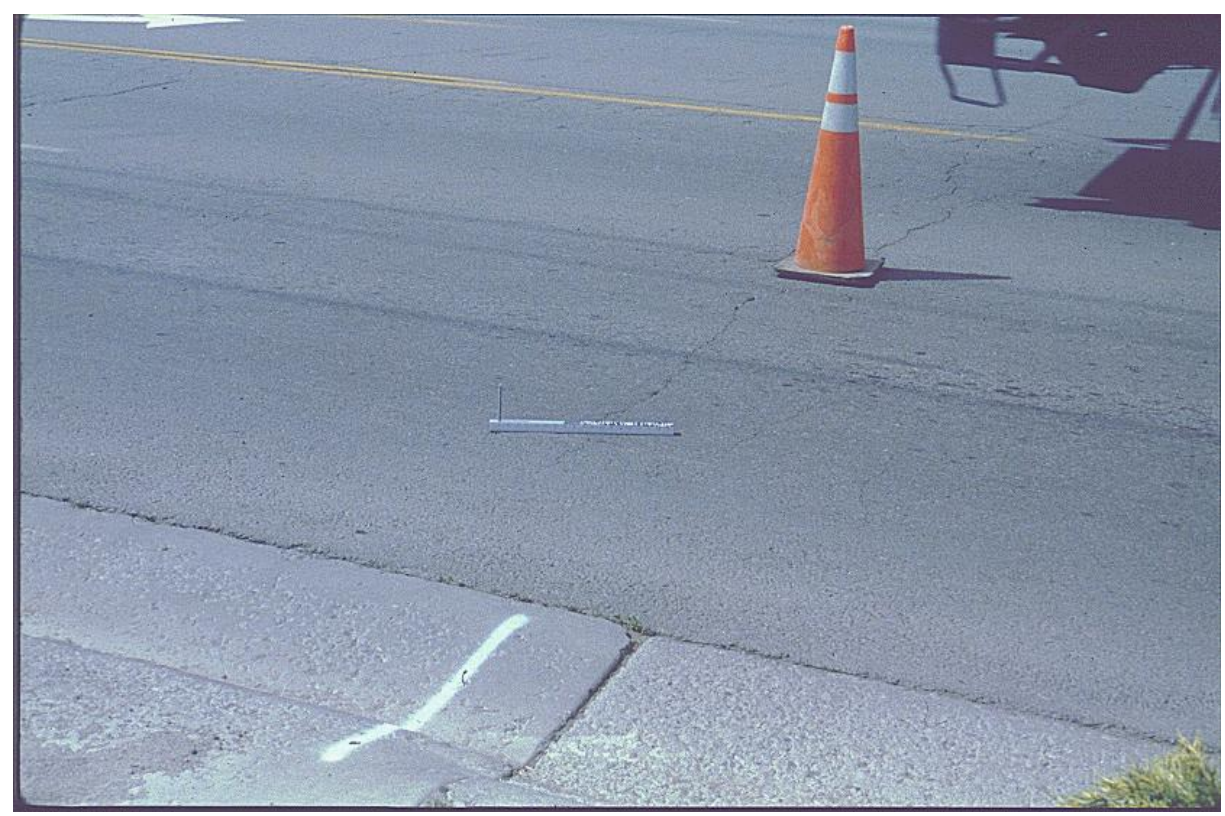

Figure C4 Illustration for Moderate Cracking on Asphalt Pavements 


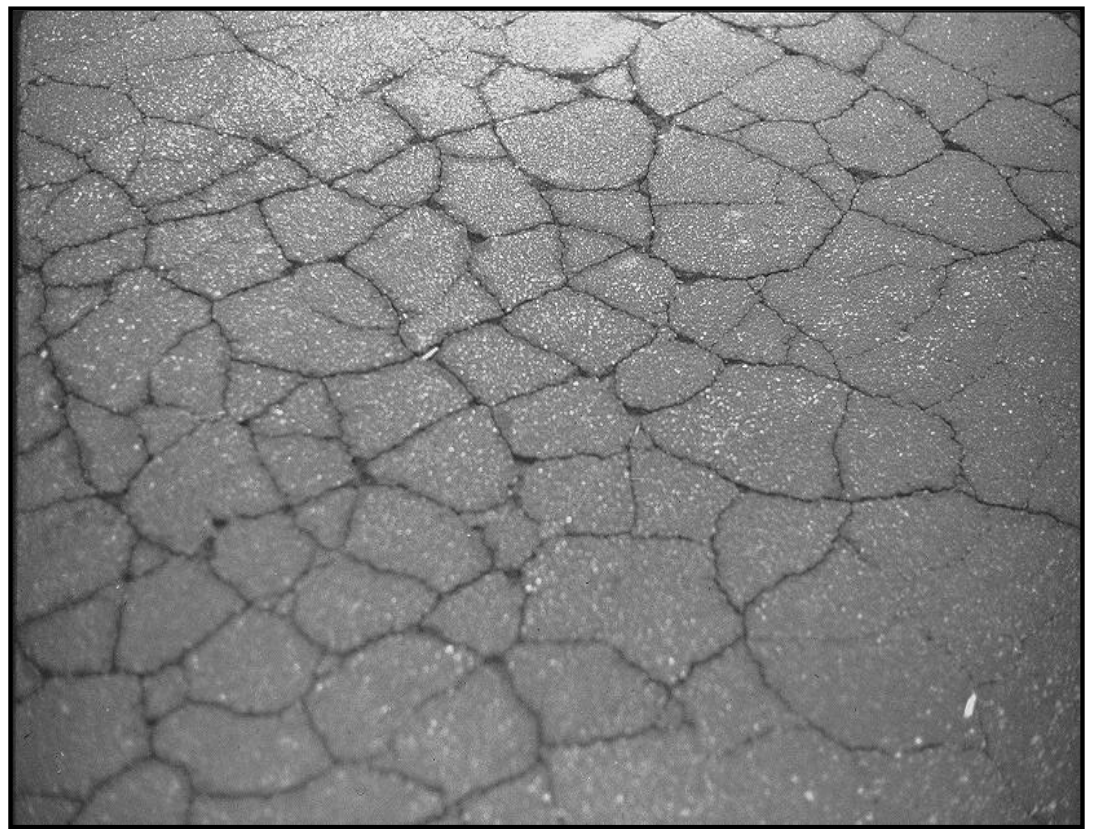

Figure C5 Illustration for Severe and Extensive Cracking on Asphalt Pavements

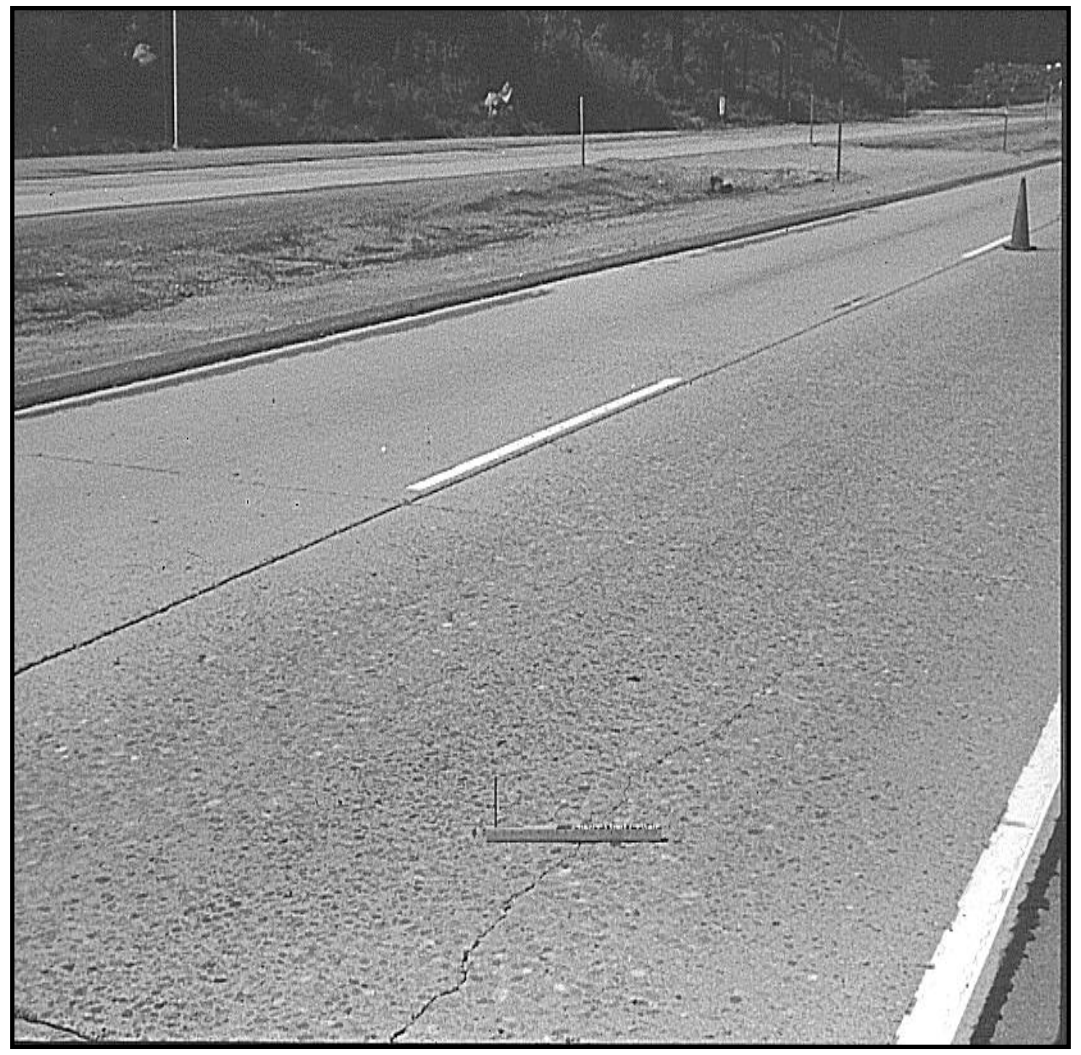

Figure C6 Illustration for Light Cracking on PCC Pavements 


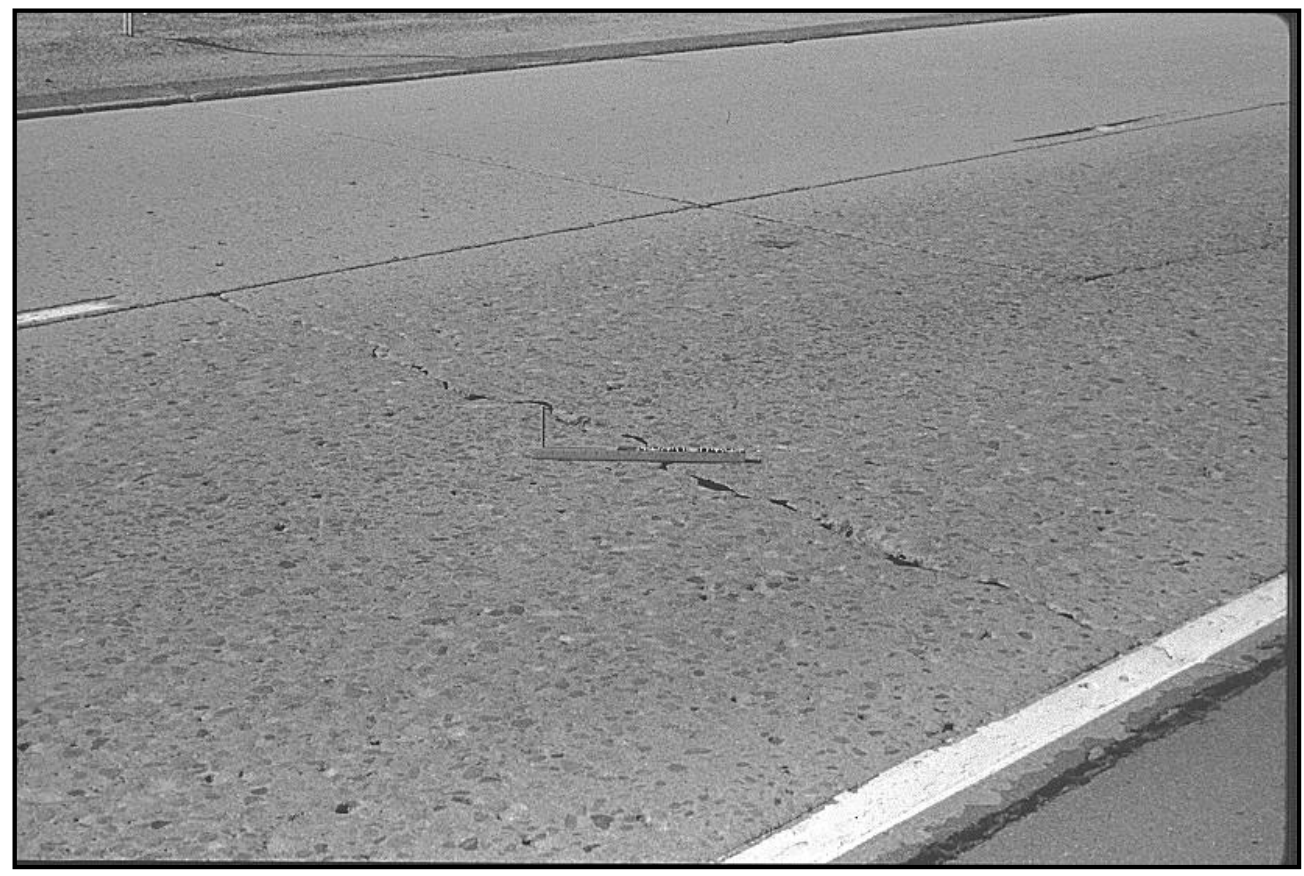

Figure C7 Illustration for Moderate Cracking on PCC Pavements

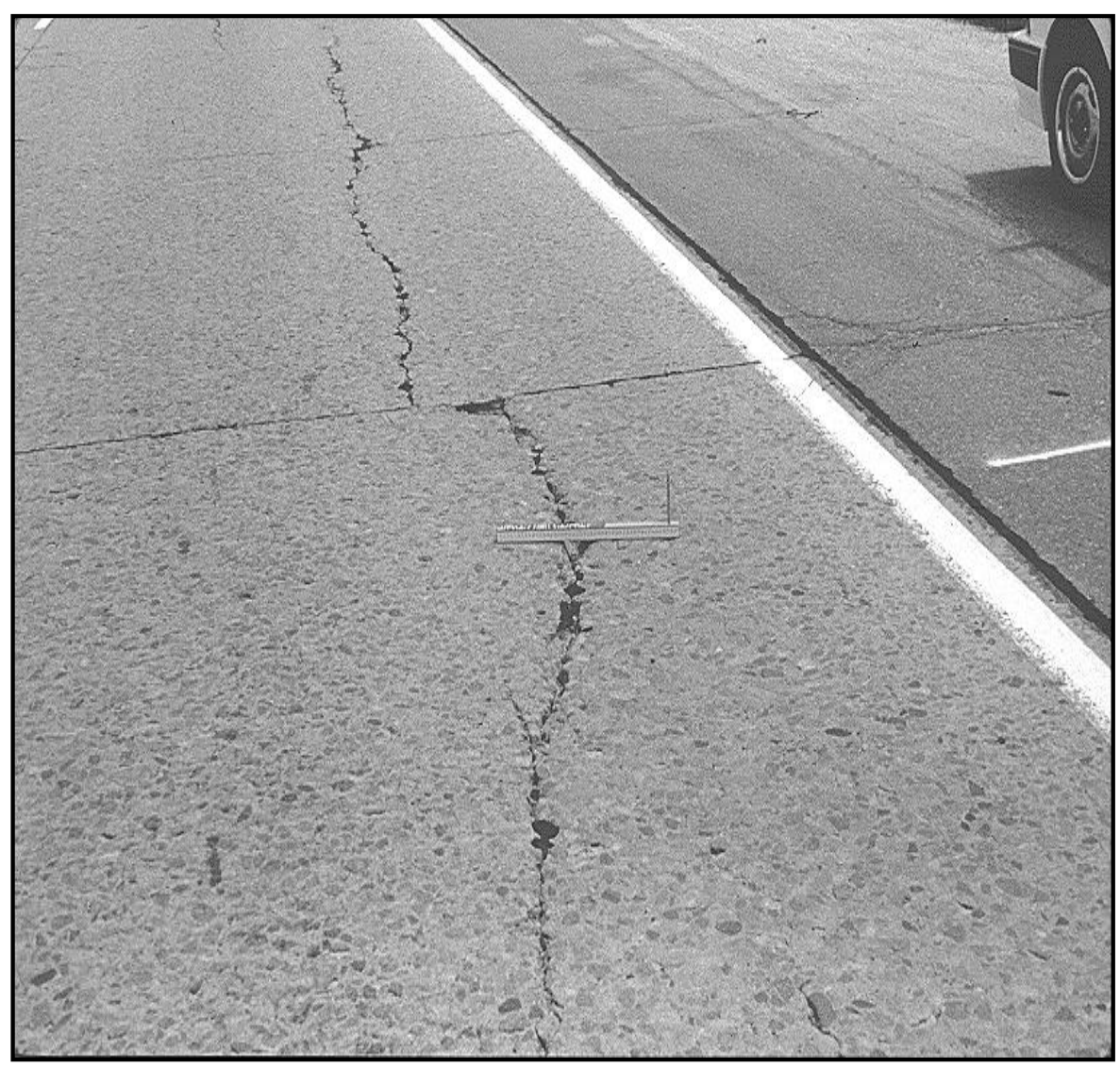

Figure C8 Illustration for Severe Cracking on PCC Pavements 
Table C1: Definitions of Cracking Severity in Asphalt Pavements

\begin{tabular}{|l|l|l|}
\hline Severity of Cracking & Single Crack & Fatigue Cracks \\
\hline Light Cracking & $\begin{array}{l}\text { Crack width less than 0.25 } \\
\text { in. or sealed cracks with } \\
\text { sealant material in good } \\
\text { condition and the width } \\
\text { cannot be determined. }\end{array}$ & $\begin{array}{l}\text { An area of cracks with no } \\
\text { or only a few connecting } \\
\text { cracks; cracks are not } \\
\text { spalled or sealed; } \\
\text { pumping is not evident }\end{array}$ \\
\hline Moderate Cracking & $\begin{array}{l}\text { Crack width between 0.25 } \\
\text { and 0.75 in. }\end{array}$ & $\begin{array}{l}\text { An area of } \\
\text { interconnected cracks } \\
\text { forming a complete } \\
\text { pattern; cracks may be } \\
\text { slightly spalled; cracks } \\
\text { may be sealed; pumping } \\
\text { is not evident }\end{array}$ \\
\hline Severe Cracking & $\begin{array}{l}\text { An area of moderately or } \\
\text { severely spalled } \\
\text { interconnected cracks } \\
\text { forming a complete } \\
\text { pattern; pieces may } \\
\text { move when subjected to } \\
\text { in. }\end{array}$ & $\begin{array}{l}\text { traffic; cracks may be } \\
\text { sealed; or pumping is } \\
\text { evident }\end{array}$ \\
\hline & & \\
& &
\end{tabular}

Table C2: Definitions of Cracking Severity in PCC Pavements

\begin{tabular}{|l|l|}
\hline Severity of Cracking & Single Crack \\
\hline Light Cracking & $\begin{array}{l}\text { Crack widths }<0.125 \text { in or } \\
\text { width too fine to be } \\
\text { determined. }\end{array}$ \\
\hline Moderate Cracking & $\begin{array}{l}\text { Crack widths between } 0.125 \\
\text { in. and } 0.5 \text { in. }\end{array}$ \\
\hline Severe Cracking & $\begin{array}{l}\text { Crack width more than } 0.5 \\
\text { in. }\end{array}$ \\
\hline
\end{tabular}




\section{APPENDIX D}

\section{DESCRIPTIONS OF TREATMENTS FOR ASPHALT PAVEMENTS}

This sheet contains the descriptions of the treatments used in the questionnaire.

TABLE D1: Pavement Treatments for Asphalt Pavements

\begin{tabular}{|c|c|c|}
\hline CODE & TREATMENT & TREATMENT DESCRIPTION \\
\hline 01 & Do nothing & None. \\
\hline 02 & Crack Sealing & $\begin{array}{l}\text { Crack sealing is the placement of specialized } \\
\text { materials either above or into working cracks } \\
\text { using unique configurations to prevent intrusion } \\
\text { of water and incompressibles into the cracks. } \\
\text { Cleaning and sealing of open cracks or joints in } \\
\text { asphalt pavement and shoulders are performed } \\
\text { to prevent the entry of moisture and debris. }\end{array}$ \\
\hline 03 & Microsurfacing & $\begin{array}{l}\text { Micro-surfacing is a mixture of polymer-modified } \\
\text { asphalt emulsion, crushed mineral aggregate, } \\
\text { mineral filler, water and additive to control the } \\
\text { time to harden. It is spread onto the pavement } \\
\text { with a spreader box attached behind a truck. }\end{array}$ \\
\hline 04 & Chip Sealing (single layer) & \multirow{2}{*}{$\begin{array}{l}\text { Chip sealing is the full width treatment of the } \\
\text { surface with hot asphalt material and coarse } \\
\text { aggregate to prevent deterioration of the surface. } \\
\text { Chip seals are constructed by spraying an } \\
\text { asphalt emulsion with a liquid asphalt distributor } \\
\text { on the pavement and then spreading a layer of } \\
\text { small crushed stone with a self-propelled } \\
\text { spreader attached to a truck. }\end{array}$} \\
\hline 05 & Chip Sealing (double layers) & \\
\hline 06 & Wedge and Level & $\begin{array}{l}\text { This involves "leveling" operations to correct } \\
\text { pavement irregularities, unequal settlement and } \\
\text { surface defects can be corrected through }\end{array}$ \\
\hline 07 & Mill and Fill (Surface layer) & \multirow{2}{*}{$\begin{array}{l}\text { Milling and filling consist of milling the existing } \\
\text { surface and replacing it with a new asphalt } \\
\text { surface to the original surface elevation. }\end{array}$} \\
\hline 08 & Mill and Fill (Functional) & \\
\hline 09 & HMA Structural Overlay & $\begin{array}{l}\text { A hot-mix asphalt (HMA) overlay is applied. The } \\
\text { pavement designer will specify the type and } \\
\text { thickness of any overlay. The existing pavement } \\
\text { plus the proposed rehabilitation will be designed } \\
\text { for structural sufficiency by computing the } \\
\text { structural number of the existing pavement and } \\
\text { comparing this number with the required } \\
\text { structural number for the project. }\end{array}$ \\
\hline 10 & Asphalt Pavement Replacement & $\begin{array}{l}\text { A pavement replacement project includes } \\
\text { removal of the existing pavement structure, } \\
\text { including any subbase, and preparation of the } \\
\text { subgrade prior to placing a new pavement } \\
\text { structure. Includes rubblization of existing } \\
\text { pavement. }\end{array}$ \\
\hline
\end{tabular}




\section{APPENDIX E}

\section{DESCRIPTIONS OF TREATMENTS FOR PCC PAVEMENTS}

This sheet contains the descriptions of the treatments used in the questionnaire.

TABLE E1: Pavement Treatments for PCC Pavements

\begin{tabular}{|c|c|c|}
\hline CODE & TREATMENT & TYPE OF TREATMENT \\
\hline 01 & Do nothing & None. \\
\hline 02 & Crack/Joint Sealing & $\begin{array}{l}\text { Crack sealing is the placement of specialized } \\
\text { materials either above or into working cracks using } \\
\text { unique configurations to prevent intrusion of water } \\
\text { and incompressibles into the cracks. Cleaning and } \\
\text { sealing of open cracks or joints in PCC pavement are } \\
\text { performed to prevent the entry of moisture and } \\
\text { debris. }\end{array}$ \\
\hline 03 & Diamond Grinding & $\begin{array}{l}\text { Diamond grinding is a procedure used to restore or } \\
\text { improve pavement rideability by removing surface } \\
\text { defects (such as faults) that develop based on traffic } \\
\text { loading and environmental conditions. }\end{array}$ \\
\hline 04 & Load Transfer Retrofitting & $\begin{array}{l}\text { Retrofit joint load transfer consists of the retrofitting of } \\
\text { dowels in jointed PCCP to re-establish load transfer } \\
\text { across the contraction joints or random cracks. This } \\
\text { work consists of the cutting of slots, placing new } \\
\text { dowels or reinforcing bars therein, then cementing } \\
\text { them into place. }\end{array}$ \\
\hline 05 & Diamond Grooving & $\begin{array}{l}\text { Pavement tines or grooves are added to the PCC } \\
\text { pavement surface. }\end{array}$ \\
\hline 06 & Partial Depth Patching & $\begin{array}{l}\text { Partial depth patching is the shallow patching of small } \\
\text { areas of bituminous roadway or paved shoulder } \\
\text { surface with hot or cold bituminous mixtures and } \\
\text { hand tools to correct potholes, edge failures, and } \\
\text { other potential surface hazards. }\end{array}$ \\
\hline 07 & Full Depth Patching (Asphalt) & \multirow{2}{*}{$\begin{array}{l}\text { Full-depth patching includes the full depth removal of } \\
\text { surface and base material and replacement with } \\
\text { compacted bituminous or concrete mixture. }\end{array}$} \\
\hline 08 & $\begin{array}{l}\text { Full Depth Patching } \\
\text { (Concrete) }\end{array}$ & \\
\hline 09 & HMA Structural Overlay & \multirow{3}{*}{$\begin{array}{l}\text { A hot-mix asphalt (HMA) or PCC overlay is applied. } \\
\text { The pavement designer will specify the type and } \\
\text { thickness of any overlay. The existing pavement plus } \\
\text { the proposed rehabilitation will be designed for } \\
\text { structural sufficiency by computing the structural } \\
\text { number of the existing pavement and comparing this } \\
\text { number with the required structural number for the } \\
\text { project. }\end{array}$} \\
\hline 10 & $\begin{array}{l}\text { PCC Structural Overlay } \\
\text { (Unbonded) }\end{array}$ & \\
\hline 11 & $\begin{array}{l}\text { Crack and Seat PCC Slab, } \\
\text { and HMA Overlay }\end{array}$ & \\
\hline 12 & Reconstruct PCC Pavement & $\begin{array}{l}\text { A pavement replacement project includes removal of } \\
\text { the existing pavement structure, including any } \\
\text { subbase, and preparation of the subgrade prior to } \\
\text { placing a new pavement structure. Includes } \\
\text { rubblization of existing pavement and overlay with } \\
\text { HMA or PCC. }\end{array}$ \\
\hline
\end{tabular}


APPENDIX II

EVALUATING AVERAGE ANNUAL FREEZING INDEX 


\section{Evaluating Freezing Index}

Freezing index is evaluated for the freezing season. Using historical air temperature records measured by the Indiana State Climate Office, we assumed our freezing season to start from 1 December and ends in 28 February for a given year. This is chosen because temperatures during these months are predominantly below freezing temperature (based on historical data).

Freezing index is defined to be the cumulative average daily air temperature below freezing temperature $\left(32^{\circ} \mathrm{F}\right)$ for the entire freezing season. Mathematically it is computed using the equation:

$$
\begin{gathered}
F N D X_{\text {daily }}=\frac{1}{2} T_{\text {max }}+T_{\text {min }}-32 \\
F N D X=\sum F N D X_{\text {daily }} \text { for entire freezing season }
\end{gathered}
$$

where FNDX $_{\text {daily }}$ is the daily freezing index, $\mathrm{T}_{\max }$ is the maximum daily temperature, $\mathrm{T}_{\min }$ is the minimum daily temperature and FNDX is the annual freezing index. This equation is used for research purposes as we are often interested to determine accurately the effects of environment on pavement design and materials.

For pavement management purposes, the above equation is obviously too cumbersome to apply as it require massive amount of historical information for input to the database. In this case, we prefer to use the monthly air temperatures as an estimate. So the equation now becomes:

$$
\begin{gathered}
F N D X_{\text {month }}=\left[\frac{1}{2} T_{\max }^{*}+T_{\min }^{*}-32\right] \times n \\
F N D X=\sum F N D X_{\text {month }} \text { for entire freezing season (i.e. Dec to Feb) }
\end{gathered}
$$

where $\mathrm{FNDX}_{\text {daily }}$ is the monthly freezing index, $\mathrm{T}^{*}{ }_{\max }$ is the maximum monthly temperature, $\mathrm{T}^{*}{ }_{\text {min }}$ is the minimum monthly temperature, $\mathrm{n}$ is the number of days in a month and FNDX is the annual freezing index.

Cumulative freezing index is defined as the accumulated annual freezing index since the last structural treatment. Mathematically it is defined as:

$C F N D X=\sum F N D X$ since last structural treatment

Monthly air temperatures are available in the PMS database (until 2006). These data (1901-2009) can be obtained by request to the Indiana State Climate Office at the following website: 
http://climate.agry.purdue.edu/climate/index.asp. Fill in the request form (under "Data Request - Data Request Form") to get the data you need. Alternatively, you can go through the (extremely) tedious way to extract data under "Data Request - Automated Request".

\section{Worked Examples}

Example 1: Evaluating Freezing Index using Daily Temperatures (For Research Purposes)

The below information in Table B1 details the temperatures record from 1 November 2008 to 28 February 2009 for the weather stations in Indianapolis. We applied the equations to evaluate the freezing index for this season.

By summing up all the FNDX(daily) for the freezing period (18 November 2008 to 25 February 2009), we get a sum of $-599{ }^{\circ} \mathrm{F}$-day. Normally we will drop the minus sign. So the freezing index for this season is $599^{\circ} \mathrm{F}$-day.

Example 2: Evaluating Freezing Index using Monthly Temperatures

The below information in Table B1 details the temperatures record from November 2008 to February 2009 for the weather stations in Indianapolis. We applied the equations to evaluate the freezing index for this season.

Table B2: Worked Example to Evaluate Freezing Index using Monthly Temperature Data

\begin{tabular}{|c|c|c|c|c|c|c|c|}
\hline Month & $\begin{array}{c}\text { Max } \\
\text { Temp }\left({ }^{\circ} \mathrm{F}\right)\end{array}$ & $\begin{array}{c}\text { Min Temp } \\
\left({ }^{\circ} \mathrm{F}\right)\end{array}$ & $\begin{array}{c}\text { Ave. } \\
\text { Temp }\left({ }^{\circ} \mathrm{F}\right)\end{array}$ & $\begin{array}{c}\text { Ave Temp - } \\
32\end{array}$ & $\mathrm{n}$ & $\begin{array}{c}\text { FNDX(month) } \\
\left({ }^{\circ} \mathrm{F} \text {-day) }\right.\end{array}$ & Comment \\
\hline Nov 08 & 49 & 32 & 40.5 & & & & \\
\hline Dec 08 & 37 & 18 & $\mathbf{2 7 . 5}$ & -4.5 & 31 & -139.5 & Freezing \\
\hline Jan 09 & 29 & 12 & $\mathbf{2 0 . 5}$ & -11.5 & 31 & -356.5 & Freezing \\
\hline Feb 09 & 41 & 21 & $\mathbf{3 1}$ & -1 & 28 & -28 & Freezing \\
\hline
\end{tabular}

In this case, we get an estimated FNDX of $524{ }^{\circ} \mathrm{F}$-day. Note that this method tends to underestimate annual FNDX because we usually have some freezing at the end of November (see Example E1). 
Table B1: Worked Example to Evaluate Freezing Index using Daily Temperature Data

\begin{tabular}{|c|c|c|c|c|c|c|c|c|c|c|c|}
\hline Date & $\begin{array}{c}\text { Max Temp } \\
\left({ }^{\circ} \mathrm{F}\right)\end{array}$ & $\begin{array}{l}\text { Min } \\
\text { Temp } \\
\left({ }^{\circ} \mathrm{F}\right)\end{array}$ & $\begin{array}{c}\text { Ave. Temp } \\
\left({ }^{\circ} \mathrm{F}\right)\end{array}$ & $\begin{array}{c}\text { FNDX(daily) } \\
\left({ }^{\circ} \mathrm{F}-\text { day }\right)\end{array}$ & Comments & Date & $\begin{array}{c}\text { Max Temp } \\
\left({ }^{\circ} \mathrm{F}\right)\end{array}$ & $\begin{array}{c}\text { Min Temp } \\
\left({ }^{\circ} \mathrm{F}\right)\end{array}$ & $\begin{array}{c}\text { Ave. Temp } \\
\left({ }^{\circ} \mathrm{F}\right)\end{array}$ & $\begin{array}{c}\text { FNDX(daily) } \\
\left({ }^{\circ} \mathrm{F} \text {-day) }\right.\end{array}$ & Comments \\
\hline $11 / 1 / 2008$ & 70 & 39 & 54.5 & 22.5 & & $1 / 3 / 2009$ & 42 & 21 & 31.5 & -0.5 & Freezing \\
\hline $11 / 2 / 2008$ & 71 & 41 & 56 & 24 & & $1 / 4 / 2009$ & 44 & 26 & 35 & 3 & Freezing \\
\hline $11 / 3 / 2008$ & 71 & 48 & 59.5 & 27.5 & & $1 / 5 / 2009$ & 52 & 20 & 36 & 4 & Freezing \\
\hline $11 / 4 / 2008$ & 71 & 41 & 56 & 24 & & $1 / 6 / 2009$ & 32 & 19 & 25.5 & -6.5 & Freezing \\
\hline $11 / 5 / 2008$ & 71 & 43 & 57 & 25 & & $1 / 7 / 2009$ & 33 & 19 & 26 & -6 & Freezing \\
\hline $11 / 6 / 2008$ & 72 & 46 & 59 & 27 & & $1 / 8 / 2009$ & 31 & 18 & 24.5 & -7.5 & Freezing \\
\hline $11 / 7 / 2008$ & 72 & 48 & 60 & 28 & & $1 / 9 / 2009$ & 22 & 17 & 19.5 & -12.5 & Freezing \\
\hline $11 / 8 / 2008$ & 61 & 40 & $\begin{array}{l}50.5 \\
\end{array}$ & 18.5 & & $1 / 10 / 2009$ & 37 & 23 & 28 & -4 & Freezing \\
\hline $11 / 9 / 2008$ & 41 & 34 & 37.5 & 5.5 & & $1 / 11 / 2009$ & 33 & 23 & 28 & -4 & Freezing \\
\hline $11 / 10 / 2008$ & 36 & 29 & 32.5 & 0.5 & & $1 / 12 / 2009$ & 28 & 23 & 25.5 & -6.5 & Freezing \\
\hline $11 / 11 / 2008$ & 41 & 23 & 32 & 0 & & $1 / 13 / 2009$ & 36 & 23 & 29.5 & -2.5 & Freezing \\
\hline $11 / 12 / 2008$ & 42 & 30 & 36 & 4 & & $1 / 14 / 2009$ & 28 & 6 & 17 & -15 & Freezing \\
\hline $11 / 13 / 2008$ & 50 & 41 & 45.5 & 13.5 & & $1 / 15 / 2009$ & 27 & -4 & 11.5 & -20.5 & Freezing \\
\hline $11 / 14 / 2008$ & \begin{tabular}{l|}
53 \\
\end{tabular} & 48 & 50.5 & 18.5 & & $1 / 16 / 2009$ & 2 & -11 & -4.5 & -36.5 & Freezing \\
\hline $11 / 15 / 2008$ & \begin{tabular}{l|l}
52 \\
\end{tabular} & 38 & 45 & 13 & & $1 / 17 / 2009$ & 12 & -11 & 0.5 & -31.5 & Freezing \\
\hline $11 / 16 / 2008$ & 40 & 32 & 36 & 4 & & $1 / 18 / 2009$ & 34 & 12 & 23 & \begin{tabular}{|c|}
-9 \\
\end{tabular} & Freezing \\
\hline $11 / 17 / 2008$ & 37 & 31 & 34 & 2 & & $1 / 19 / 2009$ & 23 & 8 & 15.5 & -16.5 & Freezing \\
\hline $11 / 18 / 2008$ & 34 & 23 & 28.5 & -3.5 & Freezing & $1 / 20 / 2009$ & 24 & 9 & 16.5 & -15.5 & Freezing \\
\hline $11 / 19 / 2008$ & 34 & 21 & 27.5 & -4.5 & Freezing & $1 / 21 / 2009$ & 20 & 10 & 15 & -17 & Freezing \\
\hline $11 / 20 / 2008$ & \begin{tabular}{l|}
43 \\
\end{tabular} & 27 & 35 & 3 & Freezing & $1 / 22 / 2009$ & 32 & 12 & 22 & -10 & Freezing \\
\hline $11 / 21 / 2008$ & 36 & 20 & 28 & -4 & Freezing & $1 / 23 / 2009$ & 46 & 25 & 35.5 & 3.5 & Freezing \\
\hline $11 / 22 / 2008$ & \begin{tabular}{l|l}
32 \\
\end{tabular} & 13 & 22.5 & -9.5 & Freezing & $1 / 24 / 2009$ & 46 & 14 & 30 & -2 & Freezing \\
\hline $11 / 23 / 2008$ & 31 & 19 & 25 & -7 & Freezing & $1 / 26 / 2009$ & 16 & 9 & 12.5 & -19.5 & Freezing \\
\hline $\mid 11 / 24 / 2008$ & 43 & 20 & 31.5 & -0.5 & Freezing & $1 / 27 / 2009$ & 22 & 14 & 18 & -14 & Freezing \\
\hline $11 / 25 / 2008$ & 43 & 29 & 36 & 4 & Freezing & $1 / 28 / 2009$ & 20 & 16 & 18 & -14 & Freezing \\
\hline $11 / 27 / 2008$ & 43 & 20 & 31.5 & -0.5 & Freezing & $1 / 29 / 2009$ & 21 & 11 & 16 & -16 & Freezing \\
\hline $11 / 28 / 2008$ & 50 & 22 & 36 & 4 & Freezing & $1 / 30 / 2009$ & 26 & 16 & 21 & -11 & Freezing \\
\hline $11 / 29 / 2008$ & 42 & 20 & 31 & -1 & Freezing & $1 / 31 / 2009$ & 21 & -3 & 9 & -23 & Freezing \\
\hline $11 / 30 / 2008$ & 46 & 23 & 34.5 & 2.5 & Freezing & $2 / 1 / 2009$ & 42 & 4 & 23 & -9 & Freezing \\
\hline $12 / 1 / 2008$ & 37 & 31 & 34 & 2 & Freezing & $2 / 2 / 2009$ & 46 & 18 & 32 & 0 & Freezing \\
\hline $12 / 2 / 2008$ & 32 & 21 & 26.5 & -5.5 & Freezing & $2 / 3 / 2009$ & 34 & 13 & 23.5 & -8.5 & Freezing \\
\hline $12 / 4 / 2008$ & 44 & 21 & 32.5 & 0.5 & Freezing & $2 / 4 / 2009$ & 19 & 4 & 11.5 & -20.5 & Freezing \\
\hline $12 / 5 / 2008$ & 25 & 12 & 18.5 & -13.5 & Freezing & $2 / 5 / 2009$ & 16 & -4 & 6 & -26 & Freezing \\
\hline $12 / 6 / 2008$ & 24 & 11 & 17.5 & -14.5 & Freezing & $2 / 6 / 2009$ & 22 & -3 & 9.5 & -22.5 & Freezing \\
\hline $12 / 8 / 2008$ & 26 & 9 & 17.5 & -14.5 & Freezing & $2 / 7 / 2009$ & 47 & 15 & 31 & -1 & Freezing \\
\hline $12 / 10 / 2008$ & 50 & 31 & 40.5 & 8.5 & Freezing & $2 / 8 / 2009$ & 54 & 33 & 43.5 & 11.5 & Freezing \\
\hline $12 / 11 / 2008$ & 31 & 23 & 27 & -5 & Freezing & $2 / 9 / 2009$ & 48 & 29 & 38.5 & 6.5 & Freezing \\
\hline $12 / 12 / 2008$ & 33 & 22 & 27.5 & -4.5 & Freezing & $2 / 10 / 2009$ & 56 & 33 & 44.5 & 12.5 & Freezing \\
\hline $12 / 13 / 2008$ & 24 & 14 & 19 & -13 & Freezing & $2 / 11 / 2009$ & 59 & 51 & 55 & 23 & Freezing \\
\hline $12 / 14 / 2008$ & 38 & 21 & 29.5 & -2.5 & Freezing & $2 / 12 / 2009$ & 57 & 33 & 45 & 13 & Freezing \\
\hline $12 / 15 / 2008$ & 54 & 27 & 40.5 & 8.5 & Freezing & $2 / 13 / 2009$ & 50 & 27 & 38.5 & 6.5 & Freezing \\
\hline $12 / 16 / 2008$ & 27 & 13 & 20 & -12 & Freezing & $2 / 14 / 2009$ & 45 & 26 & 35.5 & 3.5 & Freezing \\
\hline $12 / 17 / 2008$ & 26 & 16 & 21 & -11 & Freezing & $2 / 15 / 2009$ & 34 & 20 & 27 & -5 & Freezing \\
\hline $12 / 18 / 2008$ & 23 & 18 & 20.5 & -11.5 & Freezing & $2 / 16 / 2009$ & 36 & 18 & 27 & -5 & Freezing \\
\hline $12 / 19 / 2008$ & 35 & 22 & 28.5 & -3.5 & Freezing & $2 / 17 / 2009$ & 36 & 18 & 27 & -5 & Freezing \\
\hline $12 / 20 / 2008$ & 54 & 26 & 40 & 8 & Freezing & $2 / 18 / 2009$ & 44 & 23 & 33.5 & 1.5 & Freezing \\
\hline $12 / 21 / 2008$ & 30 & 7 & 18.5 & -13.5 & Freezing & $2 / 19 / 2009$ & 52 & 18 & 35 & 3 & Freezing \\
\hline $12 / 22 / 2008$ & 10 & 0 & 5 & -27 & Freezing & $2 / 20 / 2009$ & 24 & 15 & 19.5 & -12.5 & Freezing \\
\hline $12 / 23 / 2008$ & 19 & 0 & 9.5 & -22.5 & Freezing & $2 / 21 / 2009$ & 32 & 15 & 23.5 & -8.5 & Freezing \\
\hline $12 / 24 / 2008$ & 43 & 19 & 31 & -1 & Freezing & $2 / 22 / 2009$ & 38 & 17 & 27.5 & -4.5 & Freezing \\
\hline $12 / 25 / 2008$ & \begin{tabular}{l|l}
49 \\
\end{tabular} & 13 & 31 & -1 & Freezing & $2 / 23 / 2009$ & 27 & 13 & 20 & -12 & Freezing \\
\hline $12 / 26 / 2008$ & 32 & 13 & 22.5 & -9.5 & Freezing & $2 / 24 / 2009$ & 30 & 12 & 21 & -11 & Freezing \\
\hline $12 / 27 / 2008$ & 59 & 32 & 45.5 & 13.5 & Freezing & $2 / 25 / 2009$ & 39 & 19 & 29 & -3 & Freezing \\
\hline $12 / 28 / 2008$ & 66 & 28 & 47 & 15 & Freezing & $2 / 26 / 2009$ & 58 & 31 & 44.5 & 12.5 & \\
\hline $12 / 29 / 2008$ & 40 & 22 & 31 & -1 & Freezing & $2 / 27 / 2009$ & 57 & 39 & 48 & 16 & \\
\hline $12 / 30 / 2008$ & 51 & 16 & 33.5 & 1.5 & Freezing & $2 / 28 / 2009$ & 39 & 26 & 32.5 & 0.5 & \\
\hline $12 / 31 / 2008$ & 53 & 24 & 38.5 & 6.5 & Freezing & & & & & & \\
\hline $1 / 1 / 2009$ & 25 & -5 & 10 & -22 & Freezing & & & & & & \\
\hline $1 / 2 / 2009$ & $33 \mid$ & 3 & 18 & \begin{tabular}{|c|}
-14 \\
\end{tabular} & Freezing & & & & & & \\
\hline
\end{tabular}

*Bold temperature denotes start and end of freezing season. 
$\underline{\text { APPENDIX III }}$

USING EXCEL TO PERFORM PRESERVATION PROJECT SELECTION AT THE DISTRICT LEVEL 


\section{Preservation Project Selection Using Excel Spreadsheet}

This appendix describes how to perform preservation project selection using Microsoft Excel. Make sure that the Excel Solver is installed in Microsoft Excel.

Step 1: Upon receiving the list of candidate projects from the Central Office, the District can check to confirm if rehabilitation projects are required and if it is possible to use a preservation treatment instead. The best way to test for structural condition of the pavement to aid in the checks is through the use of FWD testing and/or pavement cores.

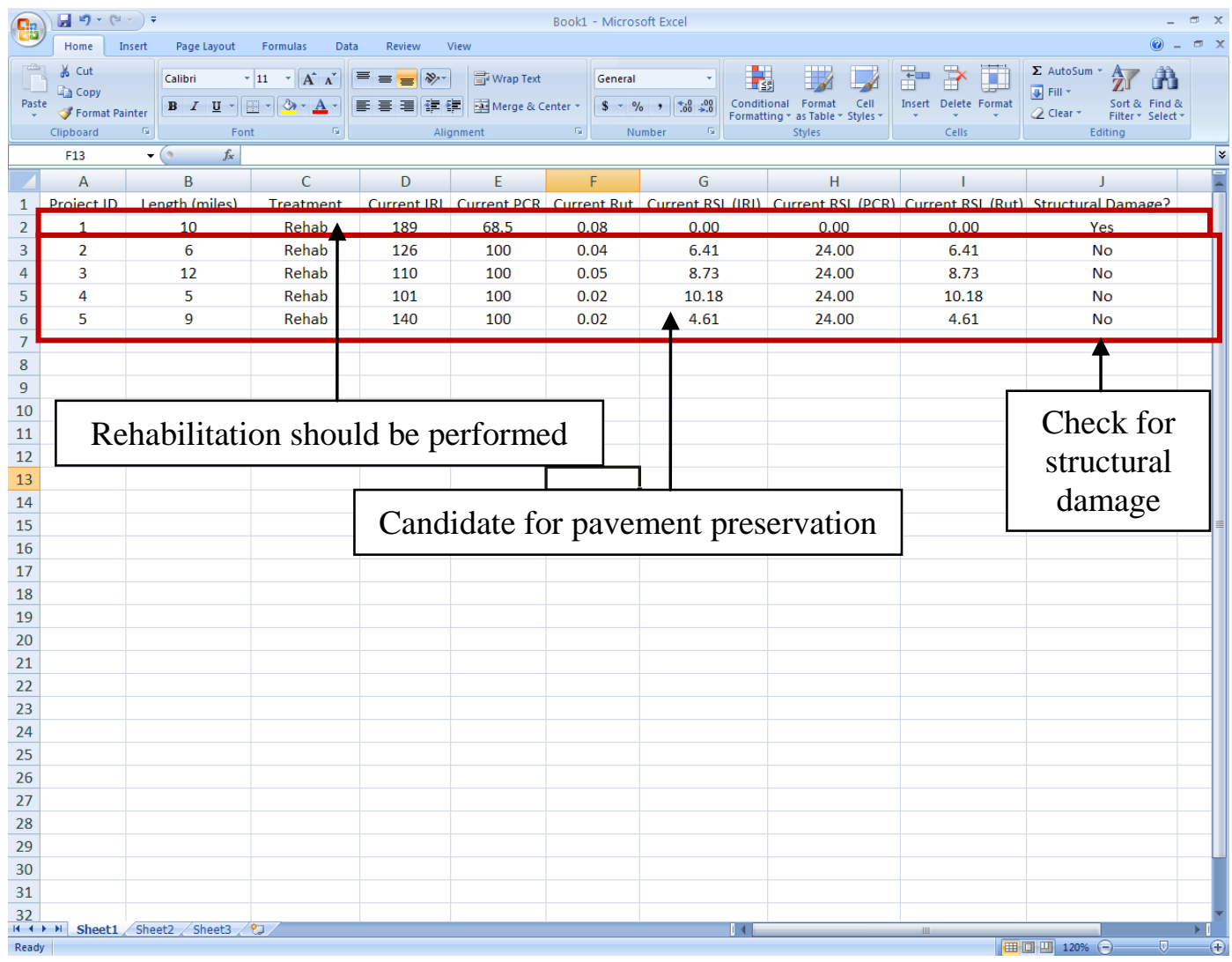

Figure III-1: Checking projects for structural deficiency 
Step 2: For projects that can be downgraded to a preservation project, add them to the candidate list and key them into an Excel Spreadsheet with the following format shown in Figure C2. Determine the preferred treatment using the guidelines in Chapter 4, RSL for each candidate project using the models in Chapter 5 and key them into the spreadsheet. For each candidate, the annual daily truck traffic and the annual freezing index has to be determined.

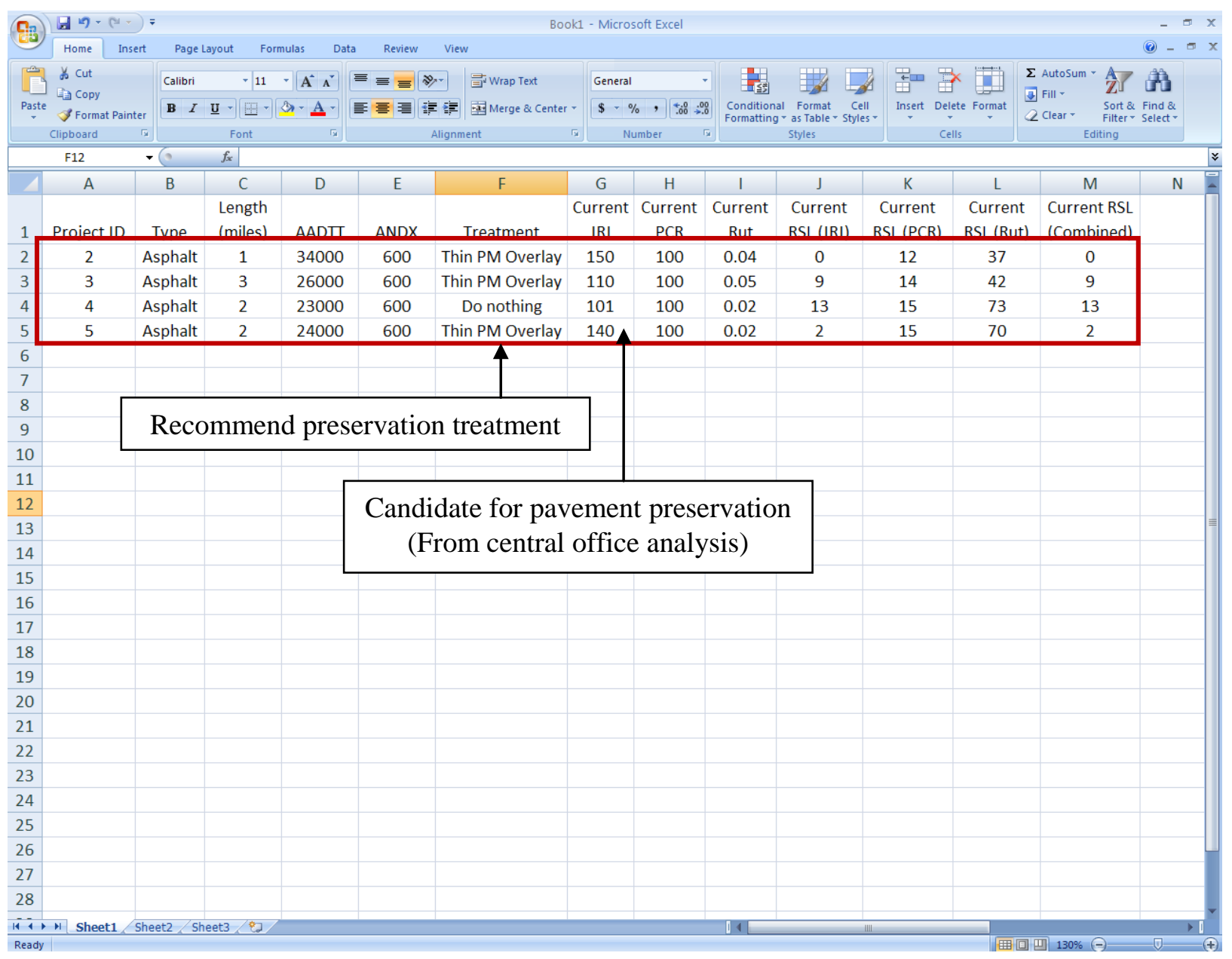

Figure III-2: Candidate list from central office recommendations 
Step 3: Districts can also identify potential projects that could be programmed in the pavement management system (e.g. thin HMA overlay, routine crack seal, routine patching, microsurfacing etc) and add them into the candidate list as shown in Figure C3. District engineers can use the treatment selection table shown in Chapter 4 as a guide.

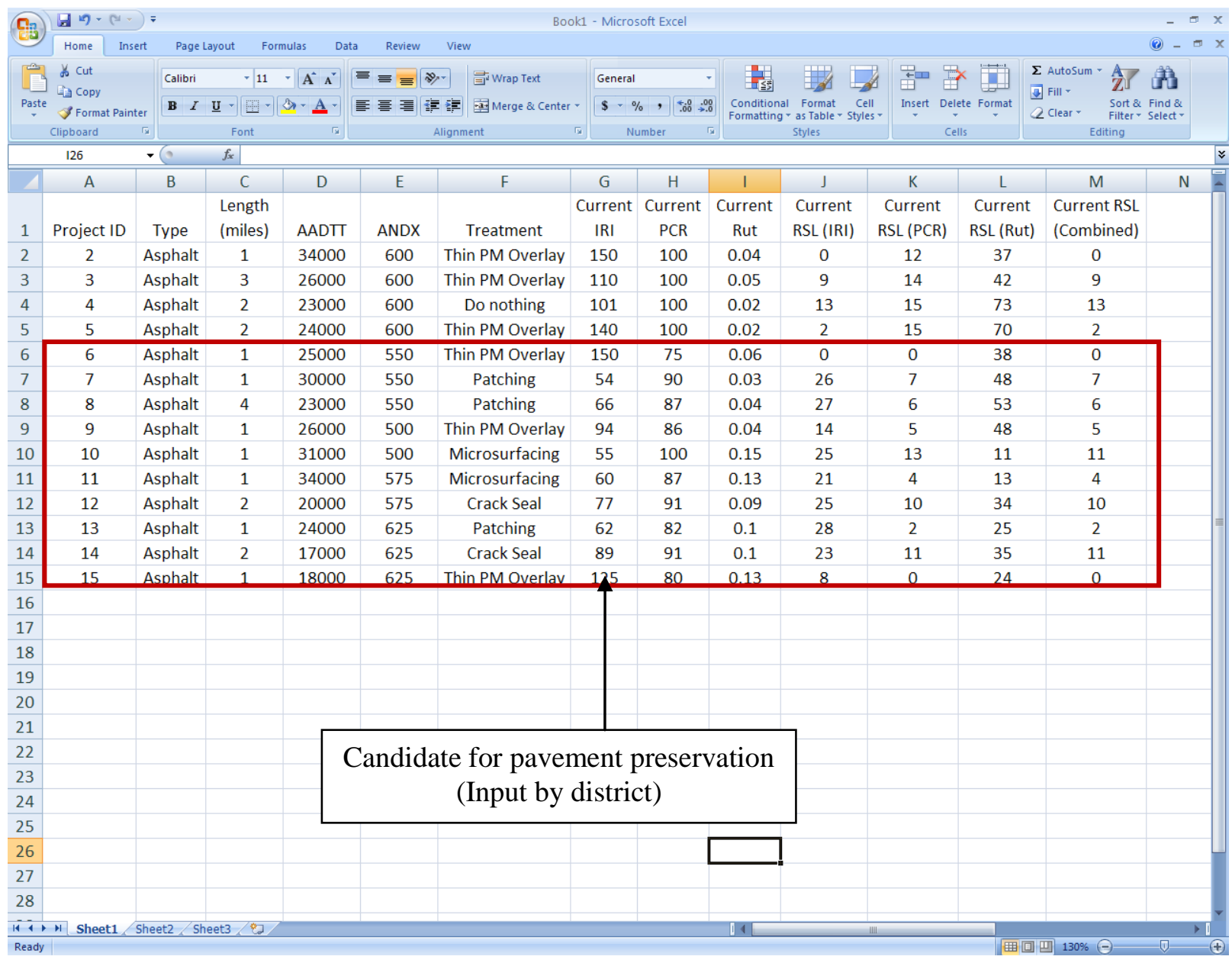

Figure III-3: Addition of projects to candidate list by district engineers 
Step 4: Compute the IRI, PCR, rut or fault after the treatment for the candidate projects and determine the new remaining service life (RSL) with the treatment. Models from Chapter 5 are used to compute the remaining service life (RSL). The remaining service life extension (RSLE) can then be determined. For each project, record the unit cost in the "Unit cost" column.

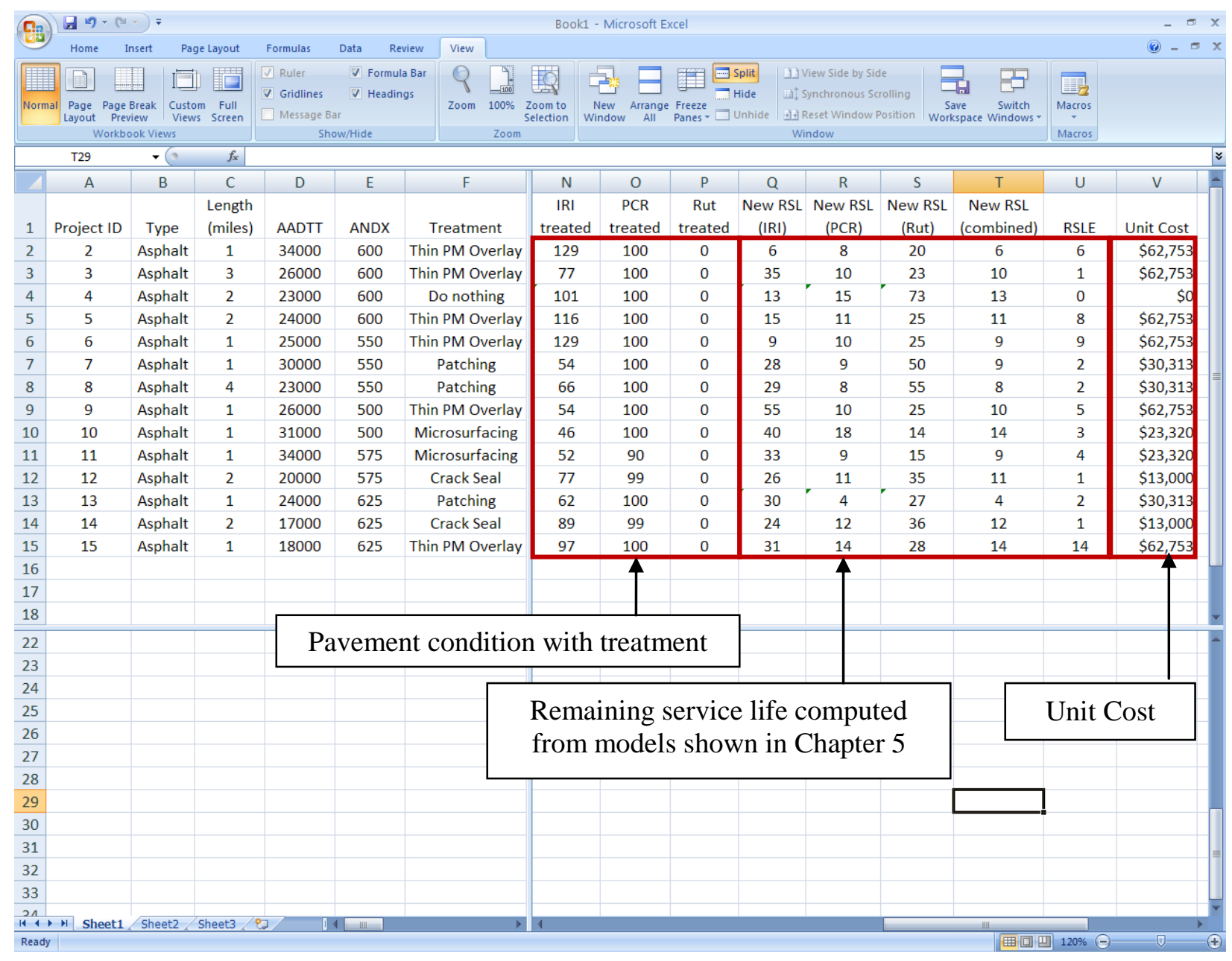

Figure III-4: Computing performance jumps, remaining service life and unit cost 
Step 5: Create the decision variable ("To Do?") column as shown in Figure C6. This represents whether the project is selected (value $=1$ ) or not selected (value $=0$ ). Create two columns entitled "Total cost" and "Total RSLE". Definitions of each column are described in Figure C6. Define the sum of cost and the sum of RSLE as shown in Figure C4.

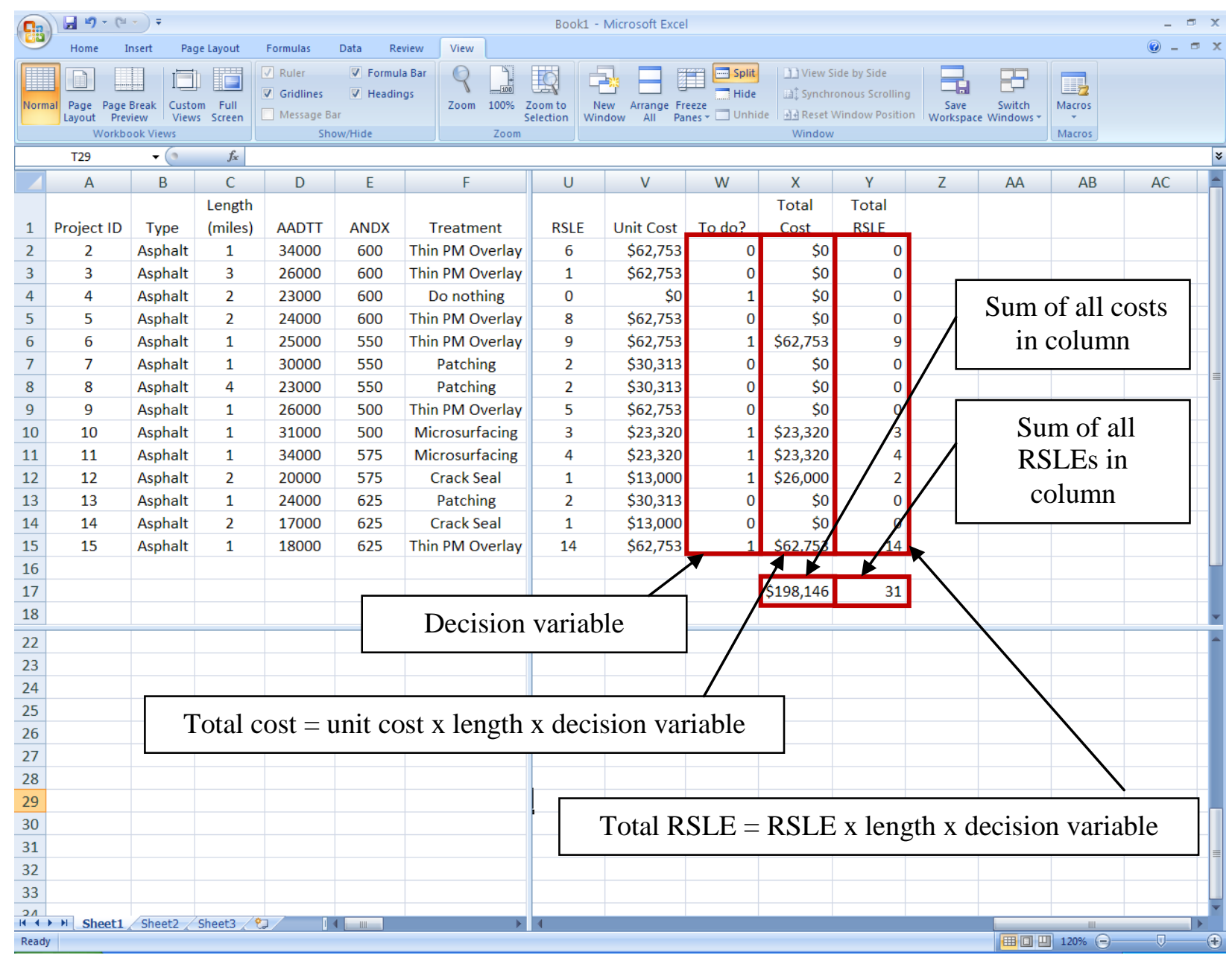

Figure III-5: Computing performance jumps, remaining service life and unit cost 
Step 6: Select Data $\Rightarrow$ Solver, a window should open up. This window is used to input the objective function and constraints for the optimization process.

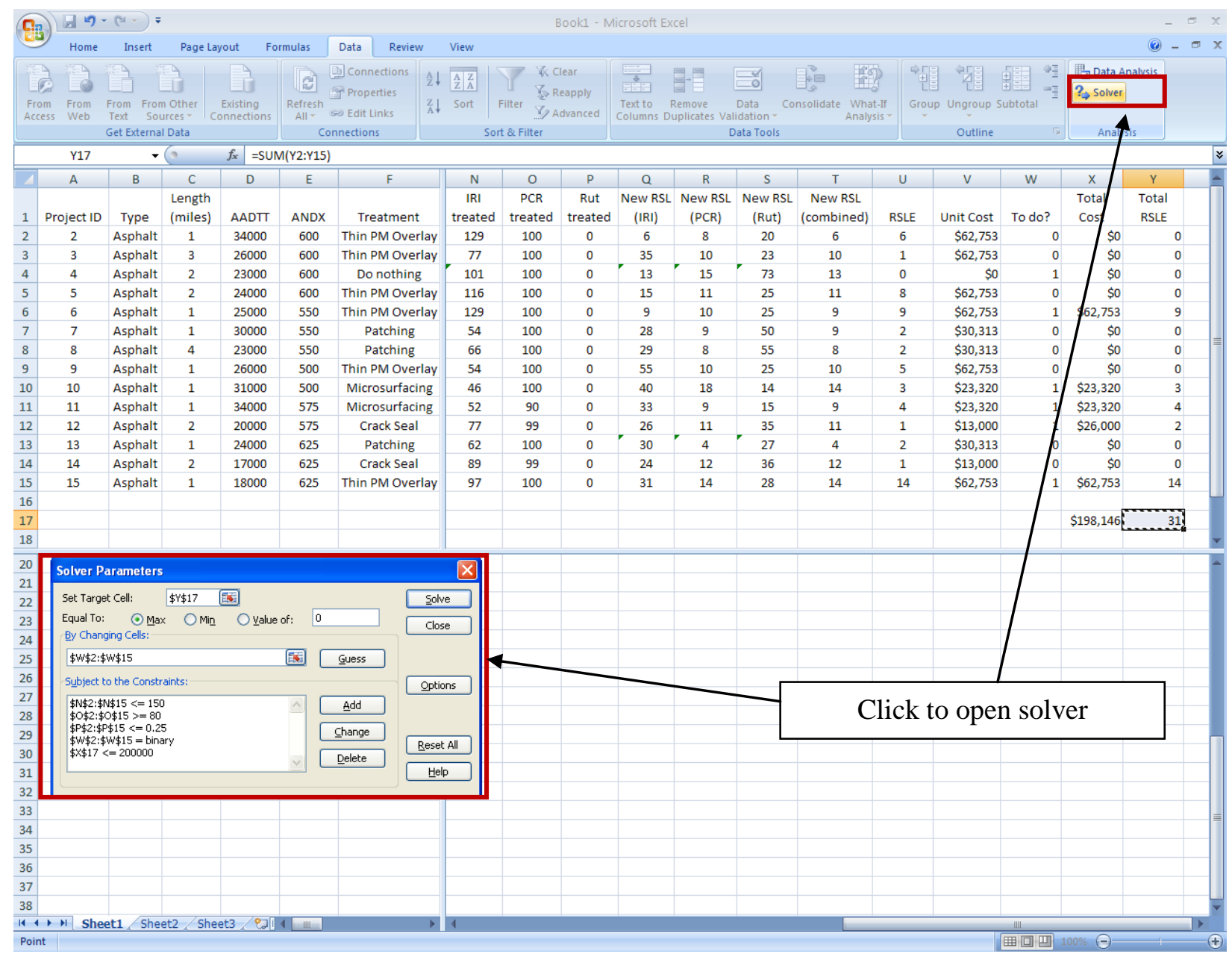

Figure III-6: Opening the Excel Solver 
Step 7: Key in the objective functions and constraints:

Objective function: Set "target cell" = cell indicating the sum of all RSLEs in column,

Maximizing life extension: Set "equals to" $=\max$

By changing cells: Select "to do" column

Subject to constraints:

IRI threshold should not be exceeded: Set "IRI treated" column $<=150$ inch per mile

PCR threshold should not be exceeded: Set "PCR treated" column $>=80$

Rut depth threshold should not be exceeded: Set "Rut treated" column $<=0.25$ inch

Decision variable must be 1 or zero: Set "To Do" column = binary

Click "Solve" to run the program.

Step 8: Interpreting solution. In the "To do" column, a value of one means that project is selected. A value of zero indicates otherwise.

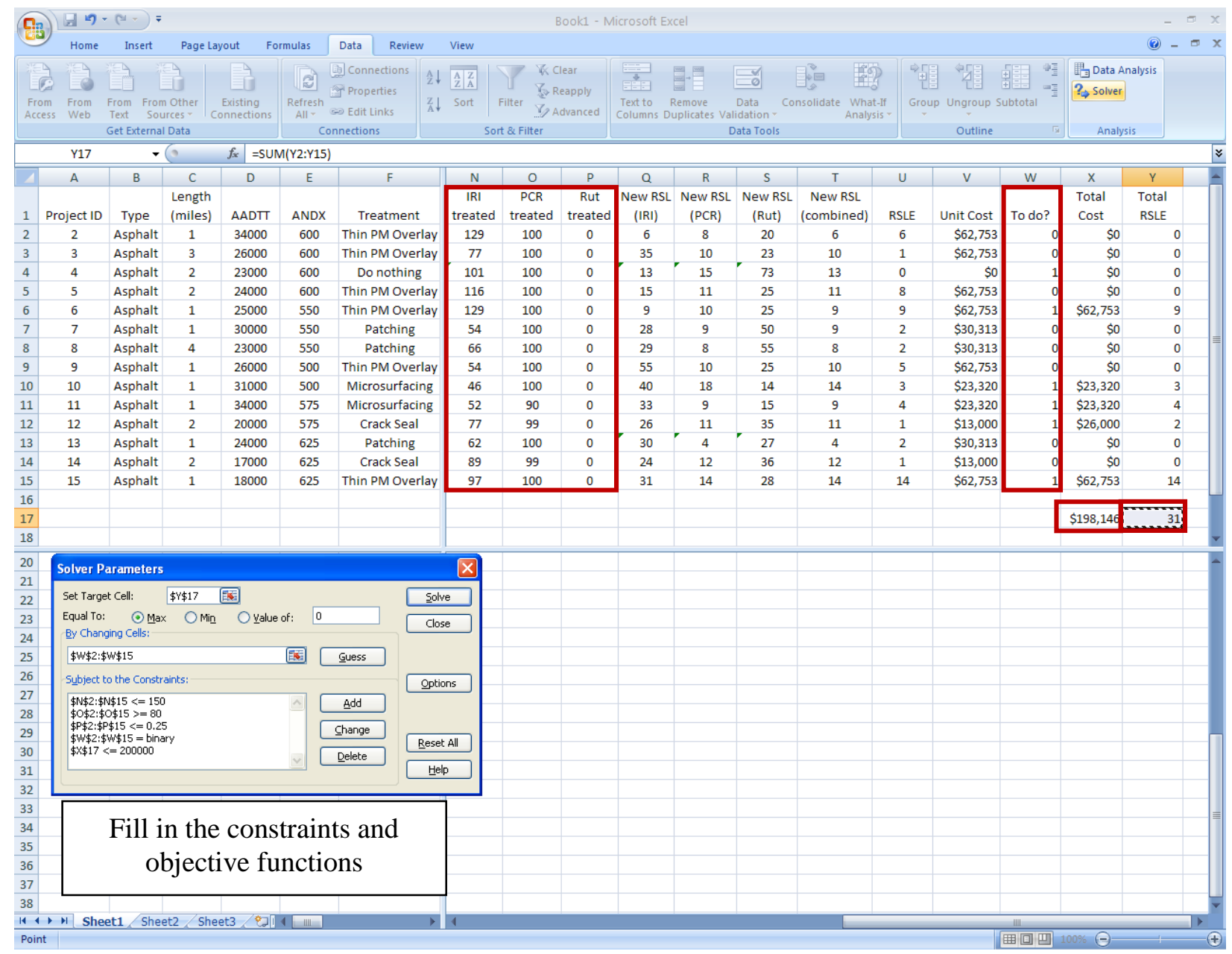

Figure III-7: Inputting objective function and constraints 